\title{
A Metathesis Approach to the Synthesis of Polyheterocyclic Structures from Oxanorbornenes
}

\author{
Jeffrey D. Winkler, * Sylvie M. Asselin, Stacey Shepard, and Jing Yuan \\ Department of Chemistry, University of Pennsylvania, Philadelphia, PA 19104 \\ winkler@sas.upenn.edu
}

\section{Supplementary Information Table of Contents:}

Experimental Section

S3-S18

${ }^{1} \mathrm{H}$ NMR Spectrum of 3

S19

${ }^{13} \mathrm{C}$ NMR Spectrum of 3

S20

${ }^{1} \mathrm{H}$ NMR Spectrum of 3.1

$\mathrm{S} 21$

${ }^{13} \mathrm{C}$ NMR Spectrum of 3.1

$\mathrm{S} 22$

${ }^{1} \mathrm{H}$ NMR Spectrum of 4

$\mathrm{S} 23$

${ }^{13} \mathrm{C}$ NMR Spectrum of 4

S24

${ }^{1} \mathrm{H}$ NMR Spectrum of 5

S25

${ }^{13} \mathrm{C}$ NMR Spectrum of 5

S26

${ }^{1} \mathrm{H}$ NMR Spectrum of 7

S27

${ }^{1} \mathrm{H}$ NMR Spectrum of 8

S28

${ }^{13} \mathrm{C}$ NMR Spectrum of 8

S29

${ }^{1} \mathrm{H}$ NMR Spectrum of 9

S30

${ }^{1} \mathrm{H}$ NMR Spectrum of 9 (in $\mathrm{C}_{6} \mathrm{D}_{6}, 70^{\circ} \mathrm{C}$ )

S31

${ }^{13} \mathrm{C}$ NMR Spectrum of 9 (in $\mathrm{C}_{6} \mathrm{D}_{6}, 70^{\circ} \mathrm{C}$ )

S32

${ }^{1} \mathrm{H}$ NMR Spectrum of 9.1

S33

${ }^{13} \mathrm{C}$ NMR Spectrum of 9.1

S34

X-Ray Structure Determination of 9.1

S35-S36

${ }^{1} \mathrm{H}$ NMR Spectrum of 10

S37

${ }^{13} \mathrm{C}$ NMR Spectrum of 10

S38

${ }^{1} \mathrm{H}$ NMR Spectrum of 11

S39

${ }^{13} \mathrm{C}$ NMR Spectrum of 11

S40

${ }^{1} \mathrm{H}$ NMR Spectrum of 12

S41

${ }^{13} \mathrm{C}$ NMR Spectrum of 12

S42

${ }^{1} \mathrm{H}$ NMR Spectrum of 13

S43

${ }^{13} \mathrm{C}$ NMR Spectrum of 13

S44

${ }^{1} \mathrm{H}$ NMR Spectrum of 15

S45

${ }^{13} \mathrm{C}$ NMR Spectrum of 15

S46

${ }^{1} \mathrm{H}$ NMR Spectrum of 16 
$\begin{array}{lr}{ }^{13} \text { C NMR Spectrum of } 16 & \text { S48 }\end{array}$

$\begin{array}{lr}{ }^{1} \mathrm{H} \text { NMR Spectrum of } 17 & \text { S49 }\end{array}$

${ }^{13}$ C NMR Spectrum of $17 \quad$ S50

${ }^{1} \mathrm{H}$ NMR Spectrum of 19

${ }^{1} \mathrm{H}$ NMR Spectrum of 19 (in $\mathrm{C}_{6} \mathrm{D}_{6}, 70^{\circ} \mathrm{C}$ ) $\quad$ S52

${ }^{13} \mathrm{C}$ NMR Spectrum of 19 (in $\mathrm{C}_{6} \mathrm{D}_{6}, 70^{\circ} \mathrm{C}$ ) S53

${ }^{1} \mathrm{H}$ NMR Spectrum of $19.1 \quad$ S54

${ }^{1} \mathrm{H}$ NMR Spectrum of 19.1 (in $\mathrm{C}_{6} \mathrm{D}_{6}, 70^{\circ} \mathrm{C}$ ) $\quad$ S55

${ }^{13} \mathrm{C}$ NMR Spectrum of 19.1 (in $\mathrm{C}_{6} \mathrm{D}_{6}, 70^{\circ} \mathrm{C}$ ) S56

${ }^{1} \mathrm{H}$ NMR Spectrum of $20 \quad$ S57

${ }^{13}$ C NMR Spectrum of $20 \quad$ S58

$\begin{array}{ll}{ }^{1} \mathrm{H} \text { NMR Spectrum of } 21 & \text { S59 }\end{array}$

${ }^{13}$ C NMR Spectrum of $21 \quad$ S60

${ }^{1} \mathrm{H}$ NMR Spectrum of $22 \quad$ S61

${ }^{13} \mathrm{C}$ NMR Spectrum of $22 \quad$ S62

${ }^{1} \mathrm{H}$ NMR Spectrum of $24.1 \quad$ S63

${ }^{13}$ C NMR Spectrum of $24.1 \quad$ S64

${ }^{1} \mathrm{H}$ NMR Spectrum of $24.2 \quad$ S65

${ }^{13}$ C NMR Spectrum of $24.2 \quad$ S66

$\begin{array}{ll}{ }^{1} \mathrm{H} \text { NMR Spectrum of } 25 & \text { S67 }\end{array}$

${ }^{13} \mathrm{C}$ NMR Spectrum of $25 \quad$ S68

$\begin{array}{ll}{ }^{1} \mathrm{H} \text { NMR Spectrum of } 25.1 & \text { S69 }\end{array}$

${ }^{13}$ C NMR Spectrum of 25.1 $\quad$ S70

$\begin{array}{ll}{ }^{1} \mathrm{H} \text { NMR Spectrum of } 26 & \text { S71 }\end{array}$

${ }^{13}$ C NMR Spectrum of $26 \quad$ S72

$\begin{array}{ll}{ }^{1} \mathrm{H} \text { NMR Spectrum of } 27 & \text { S73 }\end{array}$

$\begin{array}{ll}{ }^{13} \mathrm{C} \text { NMR Spectrum of } 27 & \text { S74 }\end{array}$

$\begin{array}{ll}{ }^{1} \mathrm{H} \text { NMR Spectrum of } 28 & \text { S75 }\end{array}$

${ }^{13}$ C NMR Spectrum of $28 \quad$ S76

$\begin{array}{ll}{ }^{1} \mathrm{H} \text { NMR Spectrum of } 29 & \text { S77 }\end{array}$

${ }^{13}$ C NMR Spectrum of $29 \quad$ S78

$\begin{array}{ll}{ }^{1} \mathrm{H} \text { NMR Spectrum of } 31 & \text { S79 }\end{array}$

$\begin{array}{ll}{ }^{13} \text { C NMR Spectrum of } 31 & \text { S80 }\end{array}$

${ }^{1} \mathrm{H}$ NMR Spectrum of $33 \quad$ S81

$\begin{array}{ll}{ }^{1} \mathrm{H} \text { NMR Spectrum of } 34 & \text { S82 }\end{array}$

${ }^{13}$ C NMR Spectrum of $34 \quad$ S83 


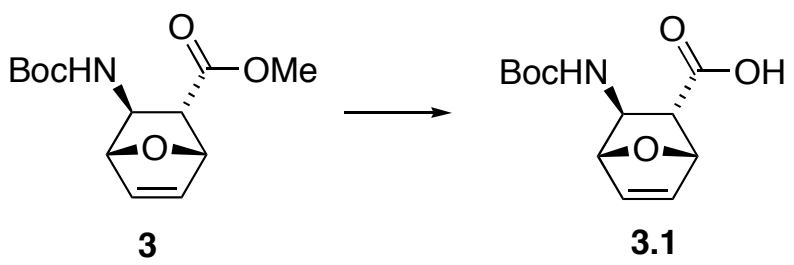

Acid 3.1: A solution of ester 3 (692 mg, $2.57 \mathrm{mmol})$ was dissolved in $\mathrm{MeOH}(50 \mathrm{~mL})$ and water $(50 \mathrm{~mL})$, and to this solution $\mathrm{LiOH}-\mathrm{H}_{2} \mathrm{O}(162 \mathrm{mg}, 3.85 \mathrm{mmol})$ was added. The hydrolysis reaction was allowed to stir at room temperature for 18 hours. The $\mathrm{MeOH}$ was evaporated, and the aqueous mixture was acidified by the careful addition of $\mathrm{c} . \mathrm{HCl}$ to achieve $\mathrm{pH} 4$. Following acidification, solid $\mathrm{NaCl}$ was added to saturate the aqueous mixture. The product was obtained by extraction with $10 \%$ isopropanol/ $\mathrm{CHCl}_{3}$. The combined organic extracts were dried over $\mathrm{Na}_{2} \mathrm{SO}_{4}$, filtered and concentrated to afford acid 3.1 (656 mg, quant.), used without further purification in subsequent transformations: ${ }^{1} \mathrm{H} \mathrm{NMR}\left(500 \mathrm{MHz}, \mathrm{CDCl}_{3}\right): \delta$ $6.66(\mathrm{~d}, J=5.1 \mathrm{~Hz}, 1 \mathrm{H}), 6.33(\mathrm{~d}, J=5.0 \mathrm{~Hz}, 1 \mathrm{H}), 5.63(\mathrm{~d}, J=5.2 \mathrm{~Hz}, 1 \mathrm{H}), 5.13(\mathrm{~d}, J=4.1 \mathrm{~Hz}, 1 \mathrm{H}), 4.80$ $(\mathrm{s}, 1 \mathrm{H}), 3.64(\mathrm{~s}, 1 \mathrm{H}), 2.85(\mathrm{~s}, 1 \mathrm{H}), 1.43(\mathrm{~s}, 9 \mathrm{H}) .{ }^{13} \mathrm{C} \mathrm{NMR}\left(125 \mathrm{MHz}, \mathrm{CDCl}_{3}\right): \delta 171.6,158.5,139.2$, 132.6, 82.9, 82.4, 78.9, 56.5, 55.5, 28.2; FTIR (thin film): 3600-2400 (br), 3318, 2979, 1707, 1638, 1522 , $1456,1394,1368,1297,1253,1164,1058,1027,987,906,860,806,699 \mathrm{~cm}^{-1}$. Exact mass calculated for $\left(\mathrm{C}_{12} \mathrm{H}_{17} \mathrm{O}_{5} \mathrm{~N}+\mathrm{Na}\right)^{+}(\mathrm{ESI}) 278.1004$, found 278.1003.

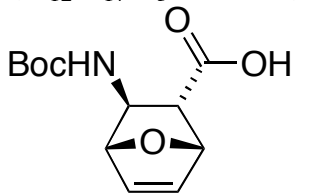

3.1

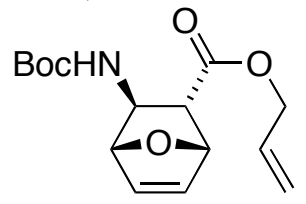

4

Allyl ester 4: To a solution of acid $3.1(172.5 \mathrm{mg}, 0.676 \mathrm{mmol})$ in methanol/water $(5 \mathrm{~mL}: 1 \mathrm{~mL})$ was added $20 \% \mathrm{Cs}_{2} \mathrm{CO}_{3}$ dropwise to until $\mathrm{pH} 7$ was obtained. The reaction mixture was evaporated to dryness and the resulting cesium salt was taken up in DMF $(10 \mathrm{~mL})$. Allyl bromide $(65 \mu \mathrm{L}, 0.743 \mathrm{mmol})$ was added and the reaction was left to stir overnight at room temperature under an argon atmosphere. Ethyl acetate was added to the reaction mixture and was washed with water several times, then brine. The organic layer was then dried over sodium sulfate and concentrated in vacuo to afford $176 \mathrm{mg}$ of crude product. The crude product was chromatographed using $30 \%$ ethyl ether/hexane $\left(\mathrm{R}_{\mathrm{F}}=0.30\right.$ in $\left.50 \% \mathrm{EE} / \mathrm{Hx}\right)$ to provide 4 as a white solid (132.8 $\mathrm{mg}, 66 \%$ yield).

mp 74-75 ${ }^{\circ}$; $[\alpha]_{\mathrm{D}}\left(\mathrm{CH}_{2} \mathrm{Cl}_{2}\right)=-112^{\circ}$; IR (film, $\left.\mathrm{cm}^{-1}\right): 3345,2977,1739,1714,1518,1367,1277,1252$, 1171, 992; ${ }^{1} \mathrm{H}$ NMR $\left(500 \mathrm{MHz}, \mathrm{CDCl}_{3}\right) \delta: 6.46(\mathrm{dd}, J=1.6 \mathrm{~Hz}, J=5.8 \mathrm{~Hz}, 1 \mathrm{H}), 6.36(\mathrm{dd}, J=1.3 \mathrm{~Hz}, J=$ $5.8 \mathrm{~Hz}, 1 \mathrm{H}), 5.86(\mathrm{~m}, 1 \mathrm{H}), 5.30(\mathrm{~d}, J=17.3 \mathrm{~Hz}, 1 \mathrm{H}), 5.23(\mathrm{~d}, J=10.6 \mathrm{~Hz}, 1 \mathrm{H}), 5.12(\mathrm{~d}, J=4.7 \mathrm{~Hz}, 1 \mathrm{H})$, 4.91 (br s, 1H), 4.78 (s, 1H), 4.55 (dd, $J=1.2 \mathrm{~Hz}, J=5.8 \mathrm{~Hz}, 2 \mathrm{H}), 4.05$ (br s, 1H), 2.73 (m, 1H), 1.44 (s, 9H, Boc); ${ }^{13} \mathrm{C}$ NMR (125 MHz, $\left.\mathrm{CDCl}_{3}\right) \delta: 170.0,155.3,135.5,135.3,131.7,118.6,85.3,79.8,78.6,65.5$, 54.4, 52.3, 28.3; HRMS: Calcd for $\mathrm{C}_{15} \mathrm{H}_{21} \mathrm{NO}_{5} \mathrm{Na}$ : 318.1317. Found: 318.1329.

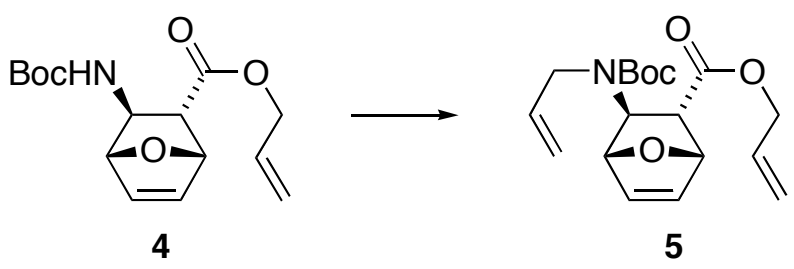


Bis-allylated metathesis substrate 5: To a solution of allyl ester 4 (1.28 g, $4.33 \mathrm{mmol})$ and allyl bromide $(0.45 \mathrm{~mL}, 5.20 \mathrm{mmol})$ in DMF (43 mL) was added $\mathrm{NaH}(95 \%$, dry) (153 mg, $6.07 \mathrm{mmol})$. The reaction was stirred for 1.5 hours at room temperature, at which time the mixture was poured into $\mathrm{pH} 7$ buffer and $\mathrm{Et}_{2} \mathrm{O}$. The layers were separated and the aqueous layer was extracted with three portions of $\mathrm{Et}_{2} \mathrm{O}$. The combined organic extracts were washed with brine, dried over $\mathrm{Na}_{2} \mathrm{SO}_{4}$, filtered and concentrated. Silica gel chromatography (20\% $\mathrm{Et}_{2} \mathrm{O}$ /petroleum ether) afforded metathesis substrate $\mathbf{5}$ as a colorless oil (1.04 g, 72\%): ${ }^{1} \mathrm{H}$ NMR $\left(500 \mathrm{MHz}, \mathrm{CDCl}_{3}\right.$ ): $\delta 6.43(\mathrm{dd}, J=1.9,5.8 \mathrm{~Hz}, 1 \mathrm{H}), 6.34(\mathrm{dd}, J=1.3,5.8 \mathrm{~Hz}, 1 \mathrm{H}), 5.82$ (ddt, $J=5.6,5.6,10.5,17.2 \mathrm{~Hz}, 2 \mathrm{H}), 5.26$ (ddd, $J=1.5,3.0,17.2 \mathrm{~Hz}, 1 \mathrm{H}$ ), 5.17 (br ddd, $J=1.1,10.5 \mathrm{~Hz}$, 1H), 5.09 (ddd, $J=1.7,3.3,17.2 \mathrm{~Hz}, 1 \mathrm{H}), 5.07-5.04(\mathrm{~m}, 2 \mathrm{H}), 4.81$ (br s, 1H), 4.50 (dt, $J=1.4,1.4,5.6$ $\mathrm{Hz}, 2 \mathrm{H}), 3.91$ (br s, 2H), $2.90(\mathrm{t}, J=4.2 \mathrm{~Hz}, 1 \mathrm{H}), 1.39(\mathrm{~s}, 9 \mathrm{H}) ;{ }^{13} \mathrm{C} \mathrm{NMR}\left(125 \mathrm{MHz}, \mathrm{CDCl}_{3}\right): \delta 170.7$, $155.4,135.8,135.6,135.5,131.8,118.2,115.1,83.8,80.0,78.4,65.3,59.1,47.9,44.8,28.2$; FTIR (thin film): 2978, 1739, 1694, 1647, 1454, 1366, $1172 \mathrm{~cm}^{-1}$. Exact mass calculated for $\left(\mathrm{C}_{18} \mathrm{H}_{25} \mathrm{O}_{5} \mathrm{~N}+\mathrm{Na}\right)^{+}(\mathrm{ESI})$ 358.1630 , found 358.1647 .

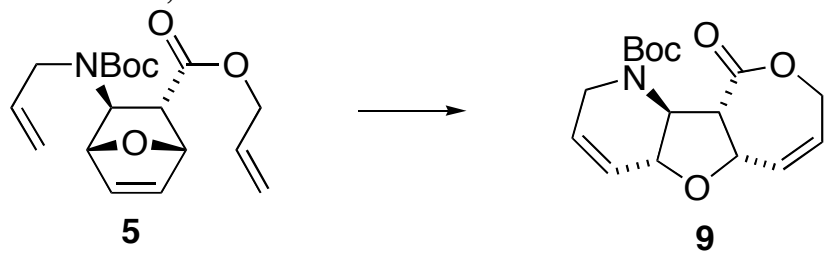

Tricyclic lactone 9: A solution of metathesis substrate 5 (100 mg, $0.298 \mathrm{mmol})$ in DCM (600 mL) was degassed by passing a stream of argon through the stirring solution for 20 minutes. The stream of argon was replaced with ethylene, and after 5 minutes, Tricyclohexylphosphine[1,3-bis(2,4,6-trimethylphenyl)4,5-dihydroimidazol-2-ylidene][benzylidene]ruthenium(IV)dichloride 6 (75 $\mathrm{mg}, 0.089 \mathrm{mmol}$ ) was added and the solution was stirred at room temperature. The conversion of starting material to a spot high in $\mathrm{R} f$ was observed by TLC $\left(50 \% \mathrm{Et}_{2} \mathrm{O}\right.$ /petroleum ether, $\mathrm{KMnO}_{4}$ stain) to occur over the course of 45 minutes. At this time, ethylene was allowed to evolve from the reaction mixture, aided by purging of the solution with a stream of argon for 45 minutes. Over this period, the initial new high $\mathrm{R} f$ spot was converted to a lower one, which was still higher than the starting material spot. Following this transformation, the flask was fitted with a reflux condenser and the solution was heated at reflux under an argon atmosphere for a further 2 hours, following the TLC to conversion to another spot of lower $\mathrm{R} f$ than the starting material. The reaction mixture was cooled to room temperature and ethyl vinyl ether $(13 \mathrm{~mL})$ was added. This solution was allowed to stir overnight. The reaction mixture was concentrated and the residue was purified by silica gel chromatography $\left(50 \% \mathrm{Et}_{2} \mathrm{O}\right.$ /petroleum ether) to afford the tricyclic product 9 (46 mg, 50\%): ${ }^{1} \mathrm{H}$ NMR $\left(500 \mathrm{MHz}, \mathrm{CDCl}_{3}\right): \delta 6.18(\mathrm{~d}, J=10.3 \mathrm{~Hz}, 1 \mathrm{H}), 6.14-6.04(\mathrm{~m}, 2 \mathrm{H}), 5.74(\mathrm{br} \mathrm{s}, 1 \mathrm{H})$, $5.08(\mathrm{~m}, 1 \mathrm{H}), 4.59(\mathrm{~m}, 2 \mathrm{H}), 4.38(\mathrm{dd}, J=6.5,12.0 \mathrm{~Hz}, 1 \mathrm{H}), 4.20(\mathrm{dd}, J=2.7,19.0 \mathrm{~Hz}, 1 \mathrm{H}), 4.07(\mathrm{~d}, J=$ $8.7 \mathrm{~Hz}, 1 \mathrm{H}), 3.85(\mathrm{dd}, J=2.7,19.0 \mathrm{~Hz}, 1 \mathrm{H}), 3.57(\mathrm{t}, J=9.7 \mathrm{~Hz}, 1 \mathrm{H}), 1.42(\mathrm{~s}, 9 \mathrm{H}) ;{ }^{13} \mathrm{C} \mathrm{NMR}(125 \mathrm{MHz}$, $\left.\mathrm{C}_{6} \mathrm{D}_{6}, 70{ }^{\circ} \mathrm{C}\right): \delta 170.7,154.5,137.9,127.2,126.6,125.8,80.3$ (br), 77.1, 77.0, 63.1, 61.2, 52.0, 48.3, 28.4; FTIR (thin film): 2975, 2927, 2850, 1740, 1694, 1645, 1435, 1394, 1368, 1177, $1148 \mathrm{~cm}^{-1}$. Exact mass calculated for $\left(\mathrm{C}_{16} \mathrm{H}_{21} \mathrm{O}_{5} \mathrm{~N}+\mathrm{Na}\right)^{+}$(ESI) 330.1317, found 330.1309. Fully opened intermediate 7 (rotamers): ${ }^{1} \mathrm{H}$ NMR $\left(500 \mathrm{MHz}, \mathrm{CDCl}_{3}\right): \delta 5.90-5.80(\mathrm{~m}, 2 \mathrm{H}), 5.74(\mathrm{ddd}, J=7.0,10.4,17.3 \mathrm{~Hz}, 1 \mathrm{H})$, 5.71-5.65 (m, 1H), 5.10-5.02 (m, 2H); Six-membered ring closed intermediate 8: ${ }^{1} \mathrm{H}$ NMR $(500 \mathrm{MHz}$, $\left.\mathrm{CDCl}_{3}\right): \delta 6.10(\mathrm{~d}, J=10.3 \mathrm{~Hz}, 1 \mathrm{H}), 5.92-5.84(\mathrm{~m}, 1 \mathrm{H}), 5.74(\mathrm{ddd}, J=7.8,10.2,17.3 \mathrm{~Hz}, 1 \mathrm{H}), 5.68(\mathrm{~d}, J$ $=8.5 \mathrm{~Hz}, 1 \mathrm{H}), 5.35-5.26(\mathrm{~m}, 2 \mathrm{H}), 5.22-5.16(\mathrm{~m}, 2 \mathrm{H}), 4.82(\mathrm{dd}, J=8.0,9.8 \mathrm{~Hz}, 1 \mathrm{H}), 4.59-4.54(\mathrm{~m}, 2 \mathrm{H})$, 4.17 (br d, $J=17.3 \mathrm{~Hz}, 1 \mathrm{H}), 4.12-4.08(\mathrm{~m}, 1 \mathrm{H}), 4.01(\mathrm{t}, J=10.5 \mathrm{~Hz}, 1 \mathrm{H}), 3.76$ (dq, $J=2.7,2.7,18.8 \mathrm{~Hz}$, $1 \mathrm{H}), 3.45(\mathrm{dd}, J=9.2,11.5 \mathrm{~Hz}, 1 \mathrm{H}), 1.40(\mathrm{~s}, 9 \mathrm{H}) \cdot ;{ }^{13} \mathrm{C} \mathrm{NMR}\left(125 \mathrm{MHz}, \mathrm{CDCl}_{3}\right): \delta 170.3,154.2,134.6$, $126.6,125.9,118.9,118.3,80.9,77.3,65.4,60.0,50.9,47.2,28.3$. 


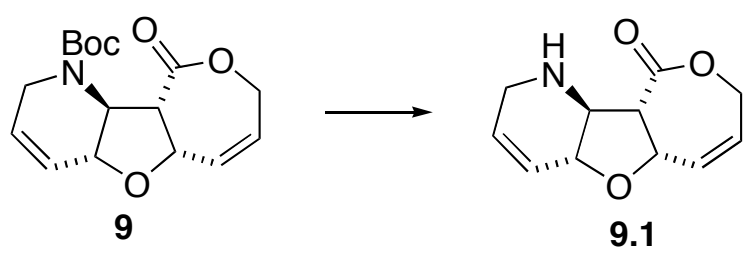

Tricyclic amino-lactone 9.1: To a solution of Boc-protected tricycle 9 (46 mg, $0.15 \mathrm{mmol})$ in DCM (10 $\mathrm{mL})$ at $0{ }^{\circ} \mathrm{C}$ was added TFA $(10 \mathrm{~mL})$. The solution was allowed to slowly warm to room temperature over the course of 1 hour. Solvent was removed en vacuo and the residue was dissolved in DCM (10 mL). 1N aq. $\mathrm{KHCO}_{3}(10 \mathrm{~mL})$ was added and the neutralization step was allowed to stir for 45 minutes. Solid $\mathrm{NaCl}$ was added to saturate the aqueous layer, which was then extracted with $\mathrm{CHCl}_{3}$ three times. The combined organic extracts were dried over $\mathrm{Na}_{2} \mathrm{SO}_{4}$, filtered and concentrated to afford the secondary amine 9.1 (31 $\mathrm{mg}, 99 \%$ ), which crystallized to afford a sample suitable for X-ray crystallographic analysis: m.pt. $124^{\circ} \mathrm{C}$ (dec.) ${ }^{1} \mathrm{H}$ NMR (500 MHz, $\mathrm{CDCl}_{3}$ ): $\delta 6.20(\mathrm{ddd}, J=1.7,3.6,10.2 \mathrm{~Hz}, 1 \mathrm{H}), 6.14-6.00(\mathrm{~m}, 2 \mathrm{H}), 5.72$ (ddd, $J=2.5,5.9,10.2 \mathrm{~Hz}, 1 \mathrm{H}), 5.16(\mathrm{dt}, J=2.6,2.7,10.9 \mathrm{~Hz}, 1 \mathrm{H}), 4.57(\mathrm{dd}, J=7.8,12.5 \mathrm{~Hz}, 1 \mathrm{H}), 4.37$ (ddd, $J=1.6,7.0,12.7 \mathrm{~Hz}, 1 \mathrm{H}), 3.98-3.94(\mathrm{~m}, 1 \mathrm{H}), 3.75(\mathrm{ddd}, J=2.8,6.1,17.6 \mathrm{~Hz}, 1 \mathrm{H}), 3.52(\mathrm{ddd}, J=2.7$, $5.7,17.6 \mathrm{~Hz}, 1 \mathrm{H}), 3.25(\mathrm{t}, J=10.8 \mathrm{~Hz}, 1 \mathrm{H}), 3.13(\mathrm{dd}, J=8.8,10.5 \mathrm{~Hz}, 1 \mathrm{H}), 2.10(\mathrm{br} \mathrm{s}, 1 \mathrm{H}) ;{ }^{13} \mathrm{C} \mathrm{NMR}$ (125 MHz, $\mathrm{CDCl}_{3}$ ): $\delta 172.2,140.0,128.8,125.48,125.45,77.0,75.3,62.3,61.8,54.1,47.3$; FTIR (thin film): 3320 (br), 2918, 2849, 1724, 1451, 1436, 1394, 1364, 1332, 1254, 1234, 1212, 1171, 1129, 1105 , $1084,1062,1028,1006,957,912,793 \mathrm{~cm}^{-1}$. Exact mass calculated for $\left(\mathrm{C}_{11} \mathrm{H}_{13} \mathrm{O}_{3} \mathrm{~N}+\mathrm{H}\right)^{+}$(ESI) 208.0974, found 208.0974.

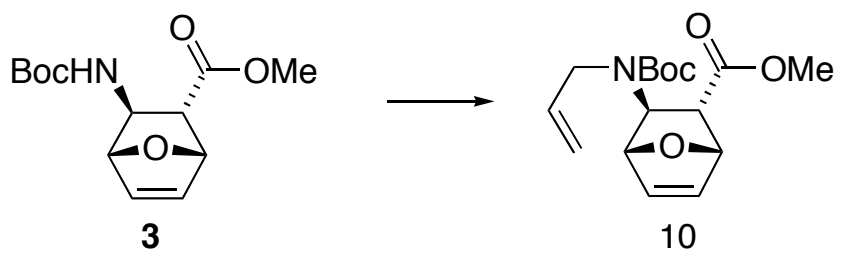

Allyl carbamate 10: To a solution of ester $3(231 \mathrm{mg}, 0.858 \mathrm{mmol})$ and allyl bromide ( $90 \mu \mathrm{L}, 1.01$ mmol) in DMF ( $8.5 \mathrm{~mL})$ was added $\mathrm{NaH}(95 \%$, dry) $(27 \mathrm{mg}, 1.05 \mathrm{mmol})$. Upon completion of the reaction (1.5 hours), the reaction was poured into $\mathrm{Et}_{2} \mathrm{O}$ and $\mathrm{pH} 7$ buffer. The aqueous layer was extracted with a further three portions of $\mathrm{Et}_{2} \mathrm{O}$. The combined organic extracts were washed with brine, dried over $\mathrm{Na}_{2} \mathrm{SO}_{4}$, filtered and concentrated. The product was purified by silica gel chromatography (20-50\% $\mathrm{Et}_{2} \mathrm{O}$ /petroleum ether) to afford allyl carbamate 10 as a colorless oil $(234 \mathrm{mg}, 88 \%):{ }^{1} \mathrm{H}$ NMR $(500 \mathrm{MHz}$, $\mathrm{CDCl}_{3}$ ): $\delta 6.43(\mathrm{dd}, J=1.9,5.8 \mathrm{~Hz}, 1 \mathrm{H}), 6.33(\mathrm{dd}, J=1.4,5.8 \mathrm{~Hz}, 1 \mathrm{H}), 5.82$ (dddd, $J=4.5,7.4,9.2,15.3$ $\mathrm{Hz}, 1 \mathrm{H}), 5.10(\mathrm{dq}, J=1.7,1.7,17.2 \mathrm{~Hz}, 1 \mathrm{H}), 5.06(\mathrm{dq}, J=1.7,1.7,10.4 \mathrm{~Hz}, 1 \mathrm{H}), 5.05-5.03(\mathrm{~m}, 1 \mathrm{H}), 4.80$ (s, 1H), 4.66-4.30 (br s, 1H), 3.95-3.85 (m, 2H), $3.61(\mathrm{~s}, 3 \mathrm{H}), 2.87(\mathrm{t}, J=4.2 \mathrm{~Hz}, 1 \mathrm{H}), 1.39(\mathrm{~s}, 9 \mathrm{H}) ;{ }^{13} \mathrm{C}$ NMR (125 MHz, $\mathrm{CDCl}_{3}$ ): $\delta$ 177.2, 160.1, 139.4, 139.1, 139.0, 117.4, 84.1 (br), 80.2, 78.5, 57.9 (br), 50.3, 45.9, 42.8, 25.3; FTIR (thin film): 3083, 3006, 2978, 1744, 1694, 1645, 1436, 1407, 1392, 1366, 1313, $1273,1245,1225,1171,1093,1048,1006,974,906,886,861,827,798 \mathrm{~cm}^{-1}$. Exact mass calculated for $\left(\mathrm{C}_{16} \mathrm{H}_{23} \mathrm{O}_{5} \mathrm{~N}+\mathrm{H}\right)^{+}(\mathrm{CI}) 310.1654$, found 310.1660 .

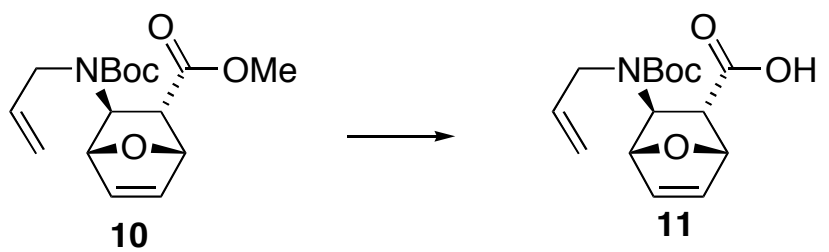


Acid 11: To a solution of methyl ester 10 (210 mg, $0.68 \mathrm{mmol})$ in $\mathrm{MeOH}(5 \mathrm{~mL})$ and water $(5 \mathrm{~mL})$ was added $\mathrm{LiOH}-\mathrm{H}_{2} \mathrm{O}$ (43 mg, $1.02 \mathrm{mmol}$ ). The mixture was stirred for 2 hours until TLC indicated consumption of the ester starting material. Methanol was removed en vacuo, and the aqueous mixture was acidified to $\mathrm{pH} 5$ by the addition of $\mathrm{c} . \mathrm{HCl}$. Solid $\mathrm{NaCl}$ was added to saturation, and the acid product was extracted with three portions of $10 \%$ isopropanol/ $\mathrm{CHCl}_{3}$. The organic extracts were dried over $\mathrm{Na}_{2} \mathrm{SO}_{4}$, filtered and concentrated to afford the crude acid 11, of sufficient purity to be used in further reactions (200 mg, quant.): ${ }^{1} \mathrm{H} \mathrm{NMR}\left(500 \mathrm{MHz}, \mathrm{CDCl}_{3}\right): \delta 6.45(\mathrm{~d}, J=5.0 \mathrm{~Hz}, 1 \mathrm{H}), 6.28(\mathrm{~d}, J=5.0 \mathrm{~Hz}, 1 \mathrm{H}), 5.59$ (dddd, $J=4.8,7.6,9.2,15.5 \mathrm{~Hz}, 1 \mathrm{H}), 5.12-5.03(\mathrm{~m}, 3 \mathrm{H}), 4.81(\mathrm{~s}, 1 \mathrm{H}), 4.28(\mathrm{br} \mathrm{d}, J=2.6 \mathrm{~Hz}, 1 \mathrm{H}), 3.91$ (br d, $J=4.7 \mathrm{~Hz}, 2 \mathrm{H}), 2.73(\mathrm{~s}, 1 \mathrm{H}), 1.40(\mathrm{~s}, 9 \mathrm{H}) ;{ }^{13} \mathrm{C}$ NMR (125 MHz, $\left.\mathrm{CDCl}_{3}\right): \delta$ 172.4, 158.3, 139.9, 134.8, 133.4, 115.6, 82.4, 80.7, 77.7, 59.0, 55.4, 45.1, 28.1; FTIR (thin film): 3620-2420 (br), 2976, 2932, 1738, 1694, 1625, 1476, 1455, 1411, 1368, 1338, 1314, 1275, 1247, 1228, 1169, 1032, 993, 974, 907,861 $\mathrm{cm}^{-1}$. Exact mass calculated for $\left(\mathrm{C}_{15} \mathrm{H}_{21} \mathrm{O}_{5} \mathrm{~N}+\mathrm{H}\right)^{+}(\mathrm{CI}) 296.1498$, found 296.1494.

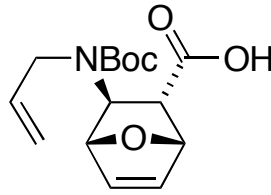

11

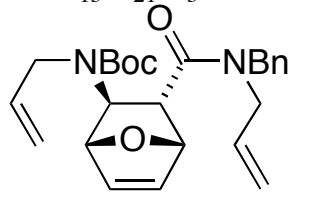

12

Lactam metathesis substrate 12: To a solution of acid $11(95 \mathrm{mg}, 0.322 \mathrm{mmol})$ and allyl benzyl amine (52 mg, $0.354 \mathrm{mmol})$ in DCM (3.2 mL) was added EDCI (68 mg, $0.354 \mathrm{mmol})$. The reaction mixutre was stirred for 14 hours at room temperature. The mixture was diluted with DCM, washed with water, and the aqueous layer extracted again with DCM. The combined organic extracts were washed with brine, dried over $\mathrm{Na}_{2} \mathrm{SO}_{4}$, filtered and concentrated. The residue was purified by silica gel chromatography $(30 \%$ $\mathrm{Et}_{2} \mathrm{O}$ /petroleum ether) to afford metathesis substrate 12 as a colorless oil $\left(75 \mathrm{mg}, 55 \%\right.$ ) (rotamers): ${ }^{1} \mathrm{H}$ NMR (500 MHz, $\left.\mathrm{CDCl}_{3}\right): \delta$ 7.34-7.09 (m, 5H), 6.44-6.42 (m, 2H), 5.86 (dddd, J = 5.1, 5.1, 10.6, 16.7 Hz, $0.67 \mathrm{H}), 5.70$ (dddd, $J=4.7,5.1,10.3,16.8 \mathrm{~Hz}, 1.33 \mathrm{H}), 5.23-4.80(\mathrm{~m}, 6 \mathrm{H}), 4.64-4.37(\mathrm{~m}, 3 \mathrm{H}), 4.14-3.72$ $(\mathrm{m}, 4 \mathrm{H}), 3.00(\mathrm{t}, J=4.1 \mathrm{~Hz}, 1 \mathrm{H}), 1.43(\mathrm{~s}, 3 \mathrm{H}), 1.38(\mathrm{~s}, 6 \mathrm{H}) ;{ }^{13} \mathrm{C} \mathrm{NMR}\left(125 \mathrm{MHz}, \mathrm{CDCl}_{3}\right): \delta 170.7,155.4$, 137.3, 136.6, 136.2 (br), 135.6, 135.4, 133.7 (br), 133.0, 132.6, 128.9, 128.5, 127.9, 127.6, 127.2, 126.1, 117.2 (br), 117.0, 115.7, 83.3, 80.1, 79.2, 79.1, 60.8, 49.6, 48.7, 48.3, 48.1, 46.4, 46.2, 44.9, 44.8, 28.3, 28.2; FTIR (thin film): 3084, 2978, 2930, 1693, 1650, 1496, 1454, 1404, 1365, 1331, 1271, 1244, 1209 , $1170,11473,1081,1051,991,924,888,861,827,774 \mathrm{~cm}^{-1}$. Exact mass calculated for $\left(\mathrm{C}_{25} \mathrm{H}_{32} \mathrm{O}_{4} \mathrm{~N}_{2}+\right.$ $\mathrm{Na})^{+}$(ESI) 425.2440, found 425.2435.

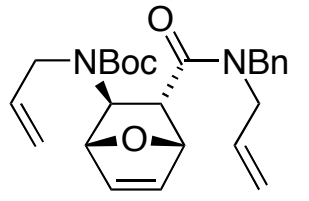

12

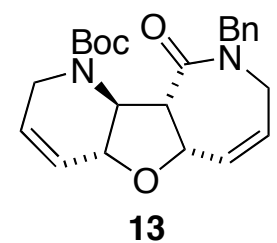

13

Tricyclic lactam 13: A solution of metathesis substrate $12(10 \mathrm{mg}, 0.0236 \mathrm{mmol})$ in DCM (47 mL) was degassed by passing a stream of argon through the stirring solution for 20 minutes. The stream of argon was replaced with ethylene, and after 5 minutes, Tricyclohexylphosphine[1,3-bis(2,4,6-trimethylphenyl)4,5-dihydroimidazol-2-ylidene][benzylidene]ruthenium(IV)dichloride 6 (6 mg, $0.007 \mathrm{mmol}$ ) was added. The solution was stirred at room temperature, monitoring the conversion of starting material to a spot high in $\mathrm{R} f$ by $\mathrm{TLC}\left(50 \% \mathrm{Et}_{2} \mathrm{O}\right.$ /petroleum ether, $\mathrm{KMnO}_{4}$ stain). This was complete after 1 hour. Ethylene was allowed to evolve from the mixture, assisted by a stream of argon bubbled through the solution for $2.5 \mathrm{~h}$. The solution was then stirred under an atmosphere of argon for a further $24 \mathrm{~h}$, over which time the initial high $\mathrm{R} f$ product was converted to one with an $\mathrm{R} f$ similar to but slightly higher than that of the initial 
starting material $\left(50 \% \mathrm{Et}_{2} \mathrm{O}\right.$ /petroleum ether, $\mathrm{KMnO}_{4}$ stain $)$. Ethyl vinyl ether $(0.5 \mathrm{~mL})$ was added to the reaction, and the solution was allowed to stir overnight. The reaction mixture was concentrated and the residue was purified by silica gel chromatography $\left(30 \% \mathrm{Et}_{2} \mathrm{O}\right.$ /petroleum ether) to afford tricyclic lactam 13 (9 mg, 95\%) as a white solid, from which crystals were obtained suitable for X-ray analysis: m.pt. $124^{\circ} \mathrm{C} ;[\alpha]_{\mathrm{D}}=-181^{\circ}\left(c=1.5 \times 10^{-3}, \mathrm{MeOH}\right)$ (rotation $=-0.272^{\circ}$ in $\left.[3 \mathrm{mg} / 2 \mathrm{~mL} \mathrm{MeOH}]\right) ;{ }^{1} \mathrm{H} \mathrm{NMR}(500$ $\mathrm{MHz}, \mathrm{CDCl}_{3}$ ): $\delta 7.30-7.23(\mathrm{~m}, 5 \mathrm{H}), 6.10(\mathrm{br} \mathrm{d}, J=9.8 \mathrm{~Hz}, 1 \mathrm{H}), 5.81$ (br d, $\left.J=10.2 \mathrm{~Hz}, 1 \mathrm{H}\right), 5.73$ (br s, $1 \mathrm{H}), 5.67$ (dddd, $J=3.1,7.3,7.3,10.3 \mathrm{~Hz}, 1 \mathrm{H}), 4.96$ (br d, $J=10.9 \mathrm{~Hz}, 1 \mathrm{H}), 4.90-4.72$ (br s, $1 \mathrm{H}), 4.70$ (br d, $J=14.5 \mathrm{~Hz}, 1 \mathrm{H}$ ), 4.47 (br d, $J=13.7 \mathrm{~Hz}, 1 \mathrm{H}$ ), 4.26 (br dd, $J=2.0,18.7 \mathrm{~Hz}, 1 \mathrm{H}$ ), 4.11-4.07 (br s, $1 \mathrm{H}), 3.87$ (br d, $J=18.0 \mathrm{~Hz}, 2 \mathrm{H}), 3.70(\mathrm{t}, J=9.7 \mathrm{~Hz}, 1 \mathrm{H}), 3.26$ (br s, $1 \mathrm{H}), 1.40(\mathrm{~s}, 9 \mathrm{H}) ;{ }^{13} \mathrm{C}$ NMR $(125$ $\left.\mathrm{MHz}, \mathrm{CDCl}_{3}\right): \delta 175.9,159.1,141.3,137.4,131.9,131.5,131.1,130.53,130.48,129.6,80.3,75.6,61.8$, 49.5, 48.8, 46.6, 40.9, 25.4; FTIR (thin film): 3309, 3044, 2975, 2927, 2849, 2249, 1692, 1659, 1650, $1644,1495,1476,1442,1368,1347,1332,1280,1231,1148,1118,1080,1019,968,911 \mathrm{~cm}^{-1}$. Exact mass calculated for $\left(\mathrm{C}_{23} \mathrm{H}_{28} \mathrm{O}_{4} \mathrm{~N}_{2}\right)^{+}(\mathrm{CI}) 396.2049$, found 396.2059.

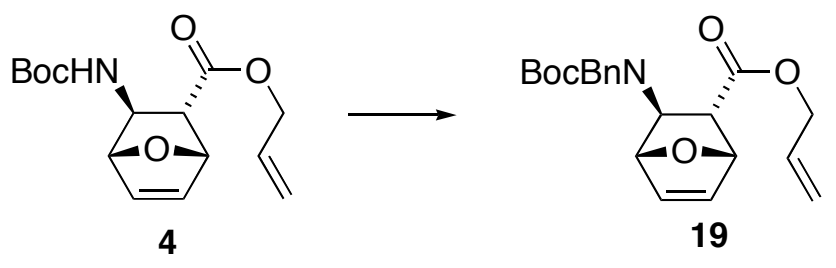

Benzyl carbamate 19: To a solution of allyl ester 4 (500 mg, $1.7 \mathrm{mmol})$ in DMF (17 mL) was added benzyl bromide $(0.3 \mathrm{~mL}, 2.54 \mathrm{mmol})$ and then $\mathrm{NaH}(95 \%$, dry) $(64 \mathrm{mg}, 2.54 \mathrm{mmol})$. This was stirred for 30 minutes at room temperature. The solution was then poured into $\mathrm{Et}_{2} \mathrm{O}$ and saturated aq. $\mathrm{NH}_{4} \mathrm{Cl}$. The aqueous layer was extracted three times with $\mathrm{Et}_{2} \mathrm{O}$, and the combined organic extracts were washed with brine and dried over $\mathrm{Na}_{2} \mathrm{SO}_{4}$. Following filtration and evaporation of solvent, the residue was purified by silica gel chromatography (15\% EtOAc/petroleum ether) to afford benzyl carbamate $19(510 \mathrm{mg}, 78 \%)$ : ${ }^{1} \mathrm{H}$ NMR (500 MHz, $\mathrm{CDCl}_{3}$ ): $\delta$ 7.40-7.10 (m, 5H), 6.50-6.25 (m, 2H), $5.86(\mathrm{ddt}, J=5.7,5.7,10.5,17.2$ $\mathrm{Hz}, 1 \mathrm{H}), 5.29$ (ddd, $J=1.4,2.9,17.2 \mathrm{~Hz}, 1 \mathrm{H}), 5.21(\mathrm{dd}, J=1.0,10.5 \mathrm{~Hz}, 1 \mathrm{H}), 5.10(\mathrm{~d}, J=12.3 \mathrm{~Hz}, 1 \mathrm{H})$, $5.06-5.01(\mathrm{~m}, 2 \mathrm{H}), 4.75-4.52(\mathrm{~m}, 4 \mathrm{H}), 2.87(\mathrm{t}, J=4.2 \mathrm{~Hz}, 1 \mathrm{H}), 1.38(\mathrm{br} \mathrm{s}, 9 \mathrm{H}) ;{ }^{1} \mathrm{H}$ NMR $(500 \mathrm{MHz}$, $\left.\mathrm{C}_{6} \mathrm{D}_{6}, 70{ }^{\circ} \mathrm{C}\right): 7.32(\mathrm{~d}, J=7.5 \mathrm{~Hz}, 2 \mathrm{H}), 7.17(\mathrm{t}, J=7.5 \mathrm{~Hz}, 2 \mathrm{H}), 7.06(\mathrm{t}, J=7.5 \mathrm{~Hz}, 1 \mathrm{H}), 6.17(\mathrm{~d}, J=5.1$ $\mathrm{Hz}, 1 \mathrm{H}), 5.98$ (dddd, $J=5.6,5.6,10.1,17.2 \mathrm{~Hz}, 1 \mathrm{H}), 5.10$ (dd, $J=1.4,17.2 \mathrm{~Hz}, 1 \mathrm{H}), 4.98(\mathrm{dd}, J=0.9$, $10.1 \mathrm{~Hz}, 1 \mathrm{H}), 4.81(\mathrm{br} \mathrm{s}, 1 \mathrm{H}), 4.78(\mathrm{~d}, J=4.6 \mathrm{~Hz}, 1 \mathrm{H}), 4.69(\mathrm{~d}, J=16.5 \mathrm{~Hz}, 1 \mathrm{H}), 4.59(\mathrm{~s}, 1 \mathrm{H}), 4.57(\mathrm{~d}, J=$ $16.0 \mathrm{~Hz}, 1 \mathrm{H}), 4.39-4.34(\mathrm{~m}, 2 \mathrm{H}), 2.86(\mathrm{t}, J=4.2 \mathrm{~Hz}, 1 \mathrm{H}), 1.39(\mathrm{~s}, 9 \mathrm{H}) ;{ }^{13} \mathrm{C}$ NMR $\left(125 \mathrm{MHz}, \mathrm{C}_{6} \mathrm{D}_{6}, 70\right.$ $\left.{ }^{\circ} \mathrm{C}\right): \delta 170.6,156.1,140.8,136.1,135.7,132.7,128.6,127.0,126.9,117.7,83.9,80.0,78.8,65.1,60.4$, 48.7, 46.5, 28.4; FTIR (thin film): 3005, 2977, 2932, 1738, 1694, 1649, 1496, 1454, 1411, 1392, 1366, $1345,1313,1274,1166,1121,1076,991,908,862 \mathrm{~cm}^{-1}$. Exact mass calculated for $\left(\mathrm{C}_{22} \mathrm{H}_{27} \mathrm{O}_{5} \mathrm{~N}+\mathrm{Na}\right)^{+}$ (ESI) 408.1787, found 408.1787.

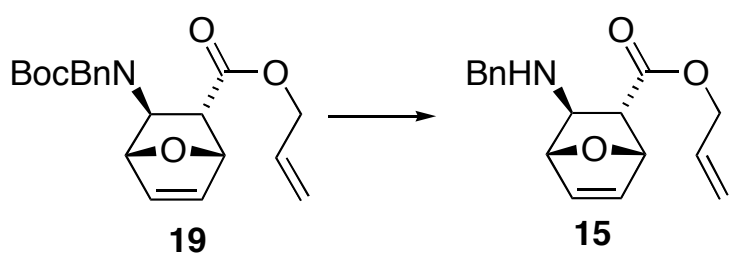

Benzylamine 15: To a solution of Boc-protected secondary amine 19 (50 $\mathrm{mg}, 0.13 \mathrm{mmol})$ in DCM (5 $\mathrm{mL})$ at $0{ }^{\circ} \mathrm{C}$ was added TFA $(5 \mathrm{~mL})$. The solution was allowed to slowly warm to room temperature over the course of 1 hour. Solvent was removed en vacuo and the residue dissolved in DCM (5 mL). $1 \mathrm{~N}$ aq. 
$\mathrm{KHCO}_{3}(5 \mathrm{~mL})$ was added and the neutralization step was allowed to stir for 45 minutes. Solid $\mathrm{NaCl}$ was added to saturate the aqueous layer, which was extracted with $\mathrm{CHCl}_{3}$ three times. The combined organic extracts were dried over $\mathrm{Na}_{2} \mathrm{SO}_{4}$, filtered and concentrated to afford the secondary amine 15 (21 mg, $56 \%):{ }^{1} \mathrm{H} \mathrm{NMR}\left(500 \mathrm{MHz}, \mathrm{CDCl}_{3}\right): \delta 7.37-7.21(\mathrm{~m}, 5 \mathrm{H}), 6.39(\mathrm{dd}, J=1.3,5.9 \mathrm{~Hz}, 1 \mathrm{H}), 6.36(\mathrm{dt}, J=1.1$, $1.1,5.8 \mathrm{~Hz}, 1 \mathrm{H}), 5.87$ (dddd, $J=5.8,5.8,10.6,17.2 \mathrm{~Hz}, 1 \mathrm{H}), 5.23(\mathrm{dt}, J=1.0,1.1,10.4 \mathrm{~Hz}, 1 \mathrm{H}), 5.11(\mathrm{~d}$, $J=4.7 \mathrm{~Hz}, 1 \mathrm{H}), 4.81(\mathrm{~s}, 1 \mathrm{H}), 4.56-4.51(\mathrm{~m}, 2 \mathrm{H}), 3.87(\mathrm{~m}, 2 \mathrm{H}), 3.18(\mathrm{~d}, J=2.9 \mathrm{~Hz}, 1 \mathrm{H}), 2.78(\mathrm{dd}, J=3.4$, $4.6 \mathrm{~Hz}, 1 \mathrm{H}), 1.63$ (br s, $1 \mathrm{H}) ;{ }^{13} \mathrm{C} \mathrm{NMR}\left(125 \mathrm{MHz}, \mathrm{CDCl}_{3}\right): \delta 171.0,139.8,135.5,135.4,131.9,128.4$, 128.0, 127.0, 118.5, 83.6, 78.5, 65.3, 62.2, 52.6, 52.1; FTIR (thin film): 3316, 3084, 3062, 3026, 3006, 2928, 1732, 1647, 604, 1496, 1454, 1364, 1312, 1280, 1193, 1118, 993, 905, 867, 736, $700 \mathrm{~cm}^{-1}$. Exact mass calculated for $\left(\mathrm{C}_{17} \mathrm{H}_{19} \mathrm{O}_{3} \mathrm{~N}+\mathrm{H}\right)^{+}$(ESI) 286.1443, found 286.1435.

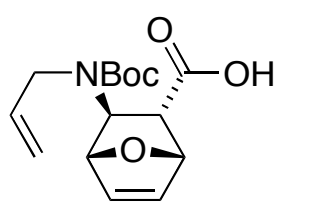

11

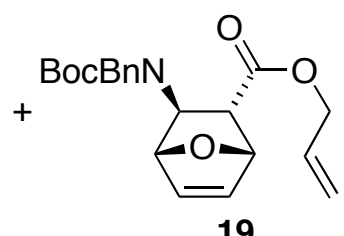

19

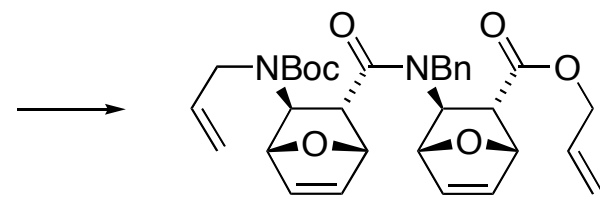

16

Dimeric tertiary amide 16: Allyl ester $19(51 \mathrm{mg}, 0.132 \mathrm{mmol})$ was dissolved in DCM (5 mL) and cooled to $0{ }^{\circ} \mathrm{C}$. Following the addition of TFA $(5 \mathrm{~mL})$, the reaction was allowed to stir for 1 hour with gradual warming to room temperature. The solvents were removed en vacuo and the crude amine salt was reconsituted in DCM $(2 \mathrm{~mL})$ and DIPEA $(0.115 \mathrm{~mL})$ was added. During this time, the acid $11(39 \mathrm{mg}$, $0.132 \mathrm{mmol})$ was dissolved in DCM $(2 \mathrm{~mL})$ and cooled to $0^{\circ} \mathrm{C}$. Oxalyl chloride $(2.0 \mathrm{M} / \mathrm{DCM}, 75 \mu \mathrm{L}$, $0.145 \mathrm{mmol}$ ) was then added, followed by a drop of DMF. The acid chloride formation was allowed to proceed for 1 hour, gradually reaching room temperature. Solvent and excess reagents were removed en vacuo. The crude acid chloride was reconstituted in DCM $(2 \mathrm{~mL})$ and added to the $0^{\circ} \mathrm{C}$ solution of the crude amine salt containing DIPEA. The acylation reaction was allowed to stir for 1 hour, with warming to room temperature. The reaction mixture was diluted with DCM, washed with water, $0.1 \mathrm{M}$ aq. $\mathrm{HCl}$, another portion of water, and the organic layer was dried over $\mathrm{Na}_{2} \mathrm{SO}_{4}$. The solution was filtered and concentrated, and the residue was purified by silica gel chromatography (15-40\% EtOAc/petroleum ether) to afford dimeric metathesis substrate 16 as a colorless oil $(29 \mathrm{mg}, 39 \%):{ }^{1} \mathrm{H} \mathrm{NMR}\left(500 \mathrm{MHz}, \mathrm{CDCl}_{3}\right): \delta$ 7.50-7.10 (m, 5H), 6.70-2.80 (m, 24H), 1.51, 1.48 (2 singlets, total 9H) rotamers, see attached spectrum; ${ }^{13} \mathrm{C}$ NMR $\left(125 \mathrm{MHz}, \mathrm{CDCl}_{3}\right)$ also rotamers, see attached spectrum: $\delta 172.3,171.8,171.7,170.6,170.4$, $155.7,155.3,138.6,138.5,137.2,136.6,136.5,136.4,136.1,135.7,135.4,135.3,135.0,133.0,132.9$, $131.8,131.3,129.1,128.8,128.6,128.5,128.4,128.3,128.0,127.5,126.7,126.5,126.4,125.2,119.5$, $118.3,116.0,115.5,83.9,83.6,83.4,83.0,80.7,80.4,80.1,79.5,79.4,79.1,78.5,78.4,67.2,66.5,65.9$, $65.4,61.5,60.5,58.1,48.1,48.0,46.9,46.9,46.5,45.23,45.19,45.0,44.8,44.6,28.4,28.3$; FTIR (thin film): 3086, 3004, 2976, 2932, 1733, 1688, 1652, 1558, 1540, 1496, 1454, 1419, 1403, 1365, 1337, 1315, $1293,1275,1254,1198,1166,1016,992,907,863,725,698 \mathrm{~cm}^{-1}$. Exact mass calculated for $\left(\mathrm{C}_{32} \mathrm{H}_{38} \mathrm{O}_{7} \mathrm{~N}_{2}\right.$ $+\mathrm{Na})^{+}(\mathrm{ESI})$ 585.2577, found 585.2584.
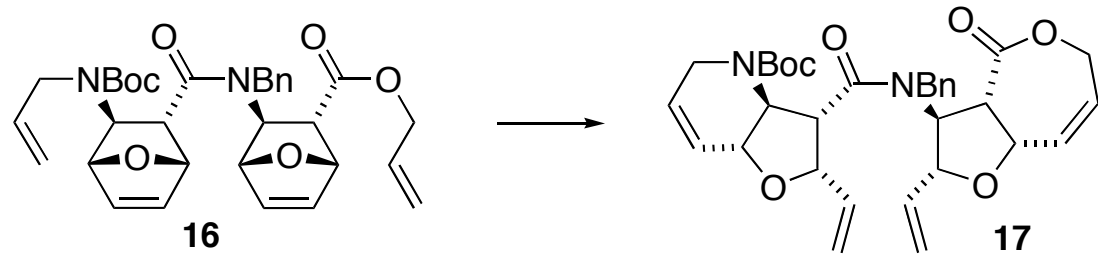
Tetracyclic tertiary amide 17: A solution of dimeric metathesis substrate 16 (29 $\mathrm{mg}, 0.0515 \mathrm{mmol})$ in DCM $(100 \mathrm{~mL})$ was degassed by passing a stream of argon through the stirring solution for 30 minutes. The stream of argon was replaced with ethylene, and after 5 minutes, Tricyclohexylphosphine[1,3bis(2,4,6-trimethylphenyl)-4,5-dihydroimidazol-2-ylidene][benzylidene]ruthenium(IV)dichloride 6 (13 $\mathrm{mg}, 0.015 \mathrm{mmol}$ ) was added. The solution was stirred at room temperature for 2 hours, at which time the stream of ethylene was replaced with a stream of argon. Ethylene was allowed to evolve from the reaction mixture in this manner over 2 hours, at which time the flask was fitted with a reflux condenser and the solution heated to reflux for 20 hours. Upon cooling to room temperature, ethyl vinyl ether $(2.25 \mathrm{~mL})$ was added. The solution was allowed to stir for a further 48 hours. The reaction mixture was concentrated and purified by silica gel chromatography $\left(50 \% \mathrm{Et}_{2} \mathrm{O} /\right.$ petroleum ether) to afford tetracycle $17(2 \mathrm{mg}, 7 \%):{ }^{1} \mathrm{H}$ NMR $\left(500 \mathrm{MHz}, \mathrm{CDCl}_{3}\right): \delta$ 7.53-7.49 $(\mathrm{m}, 2 \mathrm{H}), 7.31-7.24(\mathrm{~m}, 3 \mathrm{H}), 6.15(\mathrm{dd}, J=1.3,10.6 \mathrm{~Hz}, 1 \mathrm{H}), 6.10$ $(\mathrm{dd}, J=0.9,10.1 \mathrm{~Hz}, 1 \mathrm{H}), 6.04$ (dddd, $J=3.1,7.0,7.0,10.2 \mathrm{~Hz}, 1 \mathrm{H}), 5.79-5.70(\mathrm{~m}, 1 \mathrm{H}), 5.68-5.64(\mathrm{~m}$, $1 \mathrm{H}), 5.35-5.30(\mathrm{~m}, 2 \mathrm{H}), 5.30-5.26(\mathrm{~m}, 2 \mathrm{H}), 5.09(\mathrm{~d}, J=5.5 \mathrm{~Hz}, 1 \mathrm{H}), 5.06(\mathrm{~s}, 1 \mathrm{H}), 4.84(\mathrm{dd}, J=4.8,7.4$ $\mathrm{Hz}, 1 \mathrm{H}), 4.74-4.70(\mathrm{~m}, 1 \mathrm{H}), 4.66-4.60(\mathrm{~m}, 2 \mathrm{H}), 4.41(\mathrm{t}, J=9.2 \mathrm{~Hz}, 1 \mathrm{H}), 4.37-4.24(\mathrm{~m}, 4 \mathrm{H}), 4.14-4.08(\mathrm{~m}$, $2 \mathrm{H}), 4.06(\mathrm{dd}, J=4.8,9.0 \mathrm{~Hz}, 1 \mathrm{H}), 3.82(\mathrm{dq}, J=3.2,3.2,3.2,18.6 \mathrm{~Hz}, 1 \mathrm{H}), 3.63(\mathrm{dd}, J=8.9,10.7 \mathrm{~Hz}$, $1 \mathrm{H}), 1.47(\mathrm{~s}, 9 \mathrm{H}) ;{ }^{13} \mathrm{C}$ NMR $\left(125 \mathrm{MHz}, \mathrm{CDCl}_{3}\right): \delta 172.8,171.7,154.3,137.2,136.7,135.6,135.0,129.4$, $128.5,128.0,126.7,125.5,124.9,118.8,118.5,81.4,80.0,78.3,77.4,75.4,68.6,61.5,60.1,54.6,51.4$, 49.2, 47.2, 28.4; FTIR (thin film): 2954, 2925, 2853, 1732, 1700, 1644, 1472, 1456, 1447, 1419, 1400, $1368,1348,1298,1255,1236,1217,1161,1117,1106,1078,1043,996,930,914 \mathrm{~cm}^{-1}$. Exact mass calculated for $\left(\mathrm{C}_{32} \mathrm{H}_{38} \mathrm{O}_{7} \mathrm{~N}_{2}+\mathrm{Na}\right)^{+}$(ESI) 585.2577, found 585.2568.

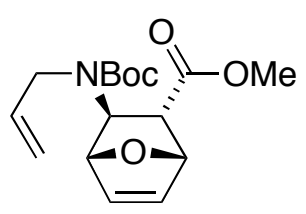

10

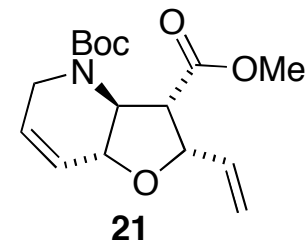

21

Bicyclic ester 21: A solution of allyl carbamate 10 (195 mg, $0.646 \mathrm{mmol})$ in DCM (1.0 L) was degassed by passing a stream of argon through the stirring solution for 20 minutes. The stream of argon was replaced with ethylene, and after 5 minutes, Tricyclohexylphosphine[1,3-bis(2,4,6-trimethylphenyl)-4,5dihydroimidazol-2-ylidene][benzylidene]ruthenium(IV)dichloride 6 (28 $\mathrm{mg}, 0.032 \mathrm{mmol}$ ) was added and the solution was stirred at room temperature for $3 \mathrm{~h}$. Conversion of the starting material to a spot high in $\mathrm{R} f$ was evidenced by TLC analysis $\left(50 \% \mathrm{Et}_{2} \mathrm{O}\right.$ /petroleum ether, $\mathrm{KMnO}_{4}$ stain). The stream of ethylene was replaced with a stream of argon to purge the solution of ethylene for $2 \mathrm{~h}$, then the solution was stirred under an atmosphere of argon overnight. The reaction was incomplete, so a further portion of catalyst was added $(18 \mathrm{mg})$ and stirring was continued for 5 hours, with argon bubbling through the solution. This served to complete the transformation, at which time the initial high $\mathrm{R} f$ product was converted to one with an $\mathrm{R} f$ similar to but slightly higher than that of the initial starting material. Ethyl vinyl ether $(28 \mathrm{~mL})$ was then added and the solution was allowed to stir overnight. The reaction mixture was concentrated and purified by silica gel chromatography (20\% EtOAc/petroleum ether) to afford ester 21 as an oil (191 mg, 98\%): ${ }^{1} \mathrm{H}$ NMR $\left(500 \mathrm{MHz}, \mathrm{CDCl}_{3}\right): \delta 6.04(\mathrm{~d}, J=10.2 \mathrm{~Hz}, 1 \mathrm{H}), 5.68(\mathrm{ddd}, J=7.8,10.2,17.6 \mathrm{~Hz}, 1 \mathrm{H})$, $5.63(\mathrm{~m}, 1 \mathrm{H}), 5.25(\mathrm{dd}, J=1.0,17.0 \mathrm{~Hz}, 1 \mathrm{H}), 5.13(\mathrm{dd}, J=0.7,10.3 \mathrm{~Hz}, 1 \mathrm{H}), 4.76(\mathrm{dd}, J=8.1,9.8 \mathrm{~Hz}$, $1 \mathrm{H}), 4.16-4.07$ (br m, 1H), 4.06-4.02 (m, 1H), 3.94 (dd, $J=10.7,11.1 \mathrm{~Hz}, 1 \mathrm{H}), 3.71$ (dq, $J=2.8,2.8,2.8$, $18.7 \mathrm{~Hz}, 1 \mathrm{H}), 3.61(\mathrm{~s}, 3 \mathrm{H}), 3.40(\mathrm{dd}, J=9.1,11.5 \mathrm{~Hz}, 1 \mathrm{H}), 1.36(\mathrm{~s}, 9 \mathrm{H}) ;{ }^{13} \mathrm{C} \mathrm{NMR}\left(125 \mathrm{MHz}, \mathrm{CDCl}_{3}\right): \delta$ 171.0, 154.2, 134.6, 126.5, 125.9, 118.7, 80.8, 77.3, 62.2, 60.0, 51.6, 51.0, 47.2, 28.3; FTIR (thin film): 2977, 2952, 2928, 2851, 1741, 1700, 1652, 1646, 1606, 1594, 1558, 1540, 1504, 1473, 1438, 1382, 1366, 
1329, 1299, 1236, 1219, 1156, 1120, 1075, 1045, 987, 962, 933, 858, 814, $755 \mathrm{~cm}^{-1}$. Exact mass calculated for $\left(\mathrm{C}_{16} \mathrm{H}_{23} \mathrm{O}_{5} \mathrm{~N}+\mathrm{Na}\right)^{+}$(ESI) 332.1474, found 332.1479.

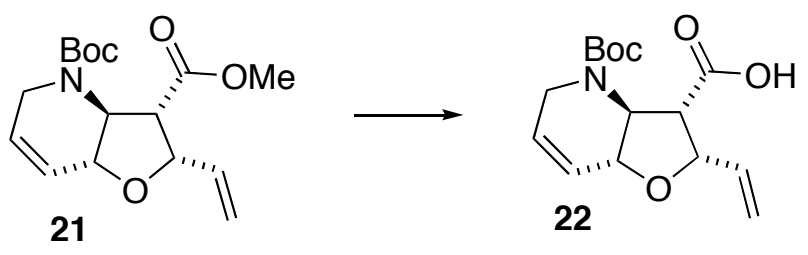

Bicyclic acid 22: To a solution of bicyclic ester 21 (162 mg, $0.548 \mathrm{mmol})$ in dioxane (5 mL) and water (5 $\mathrm{mL})$ was added $\mathrm{LiOH}-\mathrm{H}_{2} \mathrm{O}(70 \mathrm{mg}, 1.64 \mathrm{mmol})$ and the solution was stirred at room temperature for 2.5 h. The reaction mixture was poured into saturated aq. $\mathrm{NH}_{4} \mathrm{Cl}$ and then c. $\mathrm{HCl}$ was added to achieve $\mathrm{pH} 5$. This was then extracted with three portions of EtOAc. The combined organic extracts were washed with water, brine, dried over $\mathrm{Na}_{2} \mathrm{SO}_{4}$, filtered and concentrated to afford the acid $22(126 \mathrm{mg}, 82 \%)$, used crude in further transformations: ${ }^{1} \mathrm{H}$ NMR $\left(500 \mathrm{MHz} \mathrm{CDCl}_{3}\right): \delta 6.10(\mathrm{~d}, J=10.3 \mathrm{~Hz}, 1 \mathrm{H}), 5.79$ (ddd, $J=7.6$, $10.3,17.3 \mathrm{~Hz}, 1 \mathrm{H}), 5.68(\mathrm{~d}, J=9.7 \mathrm{~Hz}, 1 \mathrm{H}), 5.33(\mathrm{~d}, J=17.1 \mathrm{~Hz}, 1 \mathrm{H}), 5.17(\mathrm{~d}, J=10.4 \mathrm{~Hz}, 1 \mathrm{H}), 4.83$ $(\mathrm{dd}, J=8.0,9.7 \mathrm{~Hz}, 1 \mathrm{H}), 4.15(\mathrm{~d}, J=18.3 \mathrm{~Hz}, 1 \mathrm{H}), 4.12-4.07(\mathrm{~m}, 1 \mathrm{H}), 3.96(\mathrm{t}, J=10.9 \mathrm{~Hz}, 1 \mathrm{H}), 3.75(\mathrm{dq}$, $J=2.7,2.7,2.7,18.8 \mathrm{~Hz}, 1 \mathrm{H}), 3.38(\mathrm{dd}, J=9.1,11.5 \mathrm{~Hz}, 1 \mathrm{H}), 1.41(\mathrm{~s}, 9 \mathrm{H}) ;{ }^{13} \mathrm{C} \mathrm{NMR}\left(125 \mathrm{MHz}, \mathrm{CDCl}_{3}\right)$ : $\delta 175.3,154.5,134.2,126.6,125.7,119.0,80.8,77.4,67.0,60.0,51.1,47.2,28.4$; FTIR (thin film): 33862900 (br), 2977, 2929, 2905, 1738, 1704, 1644, 1478, 1446, 1369, 1346, 1300, 1249, 1220, 1154, 1118, $1075,1042,1001,985,968,929,912,857 \mathrm{~cm}^{-1}$. Exact mass calculated for $\left(\mathrm{C}_{15} \mathrm{H}_{21} \mathrm{O}_{5} \mathrm{~N}+\mathrm{Na}\right)^{+}(\mathrm{ESI})$ 318.1317 , found 318.1332 .

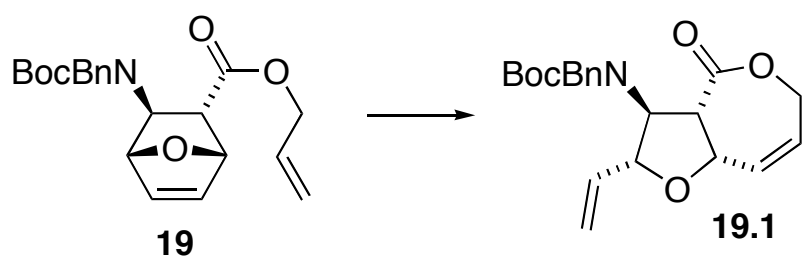

Benzylated bicyclic lactone 19.1: A solution of allyl ester 19 (53 mg, $0.137 \mathrm{mmol})$ in DCM (275 mL) was degassed by passing a stream of argon through the stirring solution for 20 minutes. The stream of argon was replaced with ethylene, and after 5 minutes, Tricyclohexylphosphine[1,3-bis $(2,4,6-$ trimethylphenyl)-4,5-dihydroimidazol-2-ylidene][benzylidene]ruthenium(IV)dichloride 6 (35 mg, 0.041 mmol) was added. The solution was stirred at room temperature for $1 \mathrm{~h}$, at which time the stream of ethylene was replaced with a stream of argon. Ethylene was allowed to evolve in this manner for 2 hours. The flask was then fitted with a reflux condenser and the solution heated to reflux for 4 hours. The solution was cooled to room temperature, and ethyl vinyl ether $(5 \mathrm{~mL})$ was added. This solution was allowed to stir overnight. The reaction mixture was concentrated and purified by silica gel chromatography (15-20\% EtOAc/petroleum ether) to afford the bicyclic lactone $19.1(30 \mathrm{mg}, 57 \%):{ }^{1} \mathrm{H}$ NMR (500 MHz, $\left.\mathrm{CDCl}_{3}\right): \delta 7.27-7.21(\mathrm{~m}, 5 \mathrm{H}), 6.12(\mathrm{~d}, J=10.6 \mathrm{~Hz}, 1 \mathrm{H}), 6.04(\mathrm{ddt}, J=3.0,6.8,6.8,10.2$ $\mathrm{Hz}, 1 \mathrm{H}), 5.44$ (ddd, $J=8.1,8.1,17.1 \mathrm{~Hz}, 1 \mathrm{H}), 5.20$ (br s, $1 \mathrm{H}), 5.14(\mathrm{~d}, J=17.1 \mathrm{~Hz}, 1 \mathrm{H}), 4.94(\mathrm{~d}, J=10.2$ $\mathrm{Hz}, 1 \mathrm{H}), 4.65$ (br s, 1H), 4.50 (br s, 2H), 4.32 (d, $J=13.7 \mathrm{~Hz}, 1 \mathrm{H}), 4.36-4.26$ (br s, 1H), 4.36-4.26 (dd, $J$ $=7.3,13.2 \mathrm{~Hz}, 1 \mathrm{H}), 4.06-3.80($ br s, $1 \mathrm{H}), 1.48(\mathrm{~s}, 9 \mathrm{H}) ;{ }^{1} \mathrm{H}$ NMR $\left(500 \mathrm{MHz}, \mathrm{C}_{6} \mathrm{D}_{6}, 70{ }^{\circ} \mathrm{C}\right): \delta 7.30(\mathrm{~d}, J=$ $7.5 \mathrm{~Hz}, 2 \mathrm{H}), 7.12(\mathrm{t}, J=7.5 \mathrm{~Hz}, 2 \mathrm{H}), 7.04(\mathrm{t}, J=7.5 \mathrm{~Hz}, 1 \mathrm{H}), 5.94(\mathrm{~d}, J=10.6 \mathrm{~Hz}, 1 \mathrm{H}), 5.62(\mathrm{ddd}, J=$ 6.0, 10.3, 17.0 Hz, 1H), 5.39 (ddt, $J=3.0,6.6,6.6,10.4 \mathrm{~Hz}, 1 \mathrm{H}), 5.17(\mathrm{~d}, J=17.0 \mathrm{~Hz}, 1 \mathrm{H}), 5.21-5.12$ (br $\mathrm{m}, 1 \mathrm{H}), 4.84(\mathrm{~d}, J=10.4 \mathrm{~Hz}, 1 \mathrm{H}), 4.72(\mathrm{br} \mathrm{s}, 2 \mathrm{H}), 4.48$ (d, $J=15.2 \mathrm{~Hz}, 1 \mathrm{H}), 4.37(\mathrm{~d}, J=15.2 \mathrm{~Hz}, 1 \mathrm{H})$, $3.86(\mathrm{dd}, J=5.7,13.3 \mathrm{~Hz}, 1 \mathrm{H}), 3.90-3.80$ (br s, $1 \mathrm{H}), 3.53(\mathrm{dd}, J=7.4,13.3 \mathrm{~Hz}, 1 \mathrm{H}), 1.37(\mathrm{~s}, 9 \mathrm{H}) ;{ }^{13} \mathrm{C}$ 
NMR (125 MHz, $\left.\mathrm{CDCl}_{3}\right): \delta 171.9,155.1,138.3,136.6,135.1,128.4,128.2,127.5,125.2,118.8,80.9$, $79.7,75.5,68.1,61.4,54.7,52.1,28.5 ;{ }^{13} \mathrm{C} \mathrm{NMR}\left(125 \mathrm{MHz}, \mathrm{C}_{6} \mathrm{D}_{6}, 70{ }^{\circ} \mathrm{C}\right): \delta 171.3,155.4,139.2,136.7$, 136.5, 128.7, 128.6, 127.6, 125.5, 117.4, 80.5, 80.3, 76.1, 69.0, 60.8, 54.7, 53.0, 28.5; FTIR (thin film): 2976, 2929, 1736, 1688, 1496, 1466, 1455, 1429, 1368, 1320, 1281, 1248, 1163, 1125, 1062, 1042, 1029, $1000,928,904,794,701,668 \mathrm{~cm}^{-1}$. Exact mass calculated for $\left(\mathrm{C}_{22} \mathrm{H}_{27} \mathrm{O}_{5} \mathrm{~N}+\mathrm{H}\right)^{+}(\mathrm{CI}) 386.1967$, found 386.1950 .

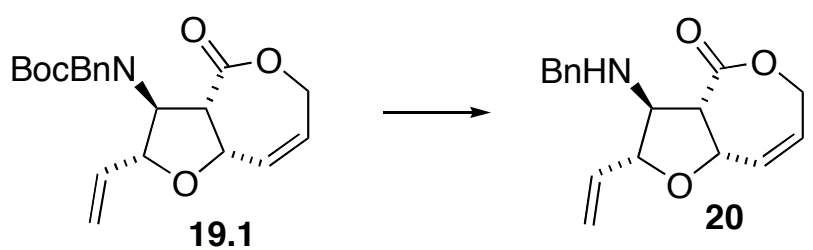

Bicyclic benzylamine 20: To a solution of Boc-protected secondary amine 19.1 (10 $\mathrm{mg}, 0.026 \mathrm{mmol})$ in DCM $(3.5 \mathrm{~mL})$ at $0{ }^{\circ} \mathrm{C}$ was added TFA $(3 \mathrm{~mL})$. The solution was allowed to slowly warm to room temperature and stirring was continued until TLC analysis indicated complete consumption of starting material (1 hour). The solvent was removed en vacuo and the residue dissolved in DCM ( $3 \mathrm{~mL}) .1 \mathrm{~N}$ aq. $\mathrm{KHCO}_{3}(3 \mathrm{~mL})$ was added and the neutralization reaction was allowed to stir for 45 minutes. Solid $\mathrm{NaCl}$ was added to saturate the aqueous layer, which was extracted with $10 \%$ isopropanol $/ \mathrm{CHCl}_{3}$ three times. The combined organic extracts were dried over $\mathrm{Na}_{2} \mathrm{SO}_{4}$, filtered and concentrated. The residue was purified by silica gel chromatography $(66 \% \mathrm{EtOAc/petroleum} \mathrm{ether)} \mathrm{to} \mathrm{afford} \mathrm{the} \mathrm{secondary} \mathrm{amine} 20$ (6 mg, 81\%): ${ }^{1} \mathrm{H}$ NMR (500 MHz, $\left.\mathrm{CDCl}_{3}\right): \delta$ 7.34-7.23 (m, 5H), $6.17(\mathrm{~d}, J=10.7 \mathrm{~Hz}, 1 \mathrm{H}), 6.11-6.05(\mathrm{~m}$, $1 \mathrm{H}), 6.00$ (ddd, $J=7.7,10.2,17.2 \mathrm{~Hz}, 1 \mathrm{H}), 5.35$ (ddd, $J=0.9,1.2,17.1 \mathrm{~Hz}, 1 \mathrm{H}), 5.23(\mathrm{ddd}, J=0.6,1.3$, $10.3 \mathrm{~Hz}, 1 \mathrm{H}), 4.69(\mathrm{dq}, J=2.4,2.4,2.4,7.2 \mathrm{~Hz}, 1 \mathrm{H}), 4.63-4.57(\mathrm{~m}, 1 \mathrm{H}), 4.31$ (ddd, $J=0.8,7.4,13.7 \mathrm{~Hz}$, $1 \mathrm{H}), 3.99(\mathrm{dd}, J=2.2,5.6 \mathrm{~Hz}, 1 \mathrm{H}), 3.95(\mathrm{dd}, J=5.8,7.6 \mathrm{~Hz}, 1 \mathrm{H}), 3.86(\mathrm{~d}, J=13.1 \mathrm{~Hz}, 1 \mathrm{H}), 3.76(\mathrm{~d}, J=$ $13.1 \mathrm{~Hz}, 1 \mathrm{H}), 3.20$ (dd, $J=2.0,7.2 \mathrm{~Hz}, 1 \mathrm{H}), 1.57$ (br s, $1 \mathrm{H}) ;{ }^{13} \mathrm{C} \mathrm{NMR}\left(125 \mathrm{MHz}, \mathrm{CDCl}_{3}\right): \delta 171.2,139.8$, 136.2, 134.8, 128.5, 128.1, 127.3, 126.2, 118.4, 86.2, 75.3, 66.6, 61.4, 53.9, 52.8; FTIR (thin film): 3316, 3028, 2848, 1732, 1682, 1495, 1471, 1454, 1403, 1384, 1276, 1214, 1171, 1100, 1049, 1027, 994, 933, 794, 740, $699 \mathrm{~cm}^{-1}$. Exact mass calculated for $\left(\mathrm{C}_{17} \mathrm{H}_{19} \mathrm{O}_{3} \mathrm{~N}+\mathrm{H}\right)^{+}(\mathrm{ESI}) 286.1443$, found 286.1453.

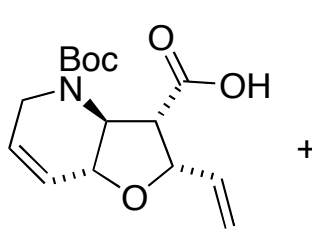

22

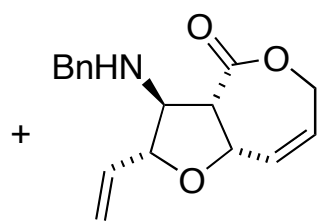

20

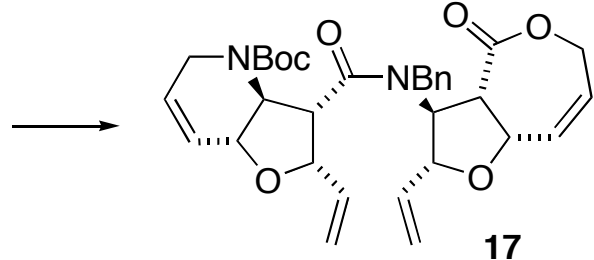

17

Tetracyclic tertiary amide 17: To a solution of 2-chloro-1-methyl pyridinium iodide (12 mg, 0.0474 mmol) and TEA $(13 \mu \mathrm{L}, 0.095 \mathrm{mmol})$ in DCM $(1.2 \mathrm{~mL})$ at $0{ }^{\circ} \mathrm{C}$ was added a solution of acid $22(10 \mathrm{mg}$, $0.0339)$ in DCM $(0.35 \mathrm{~mL})$ and then a solution of amine $20(9.7 \mathrm{mg}, 0.0339 \mathrm{~mL})$ in DCM $(0.38 \mathrm{~mL})$. This mixture was stirred for 30 minutes at $0{ }^{\circ} \mathrm{C}$, and was then allowed to warm to room temperature and stir for a further 24 hours. The reaction mixture was concentrated and purified by silica gel chromatography $(40 \%$ EtOAc/petroleum ether) to afford the tetracycle $17(3.5 \mathrm{mg}, 18 \%, 31 \%$ yield based on recovery of amine component): the spectral data matched that of the product obtained from the ring-methathesis of 272. 


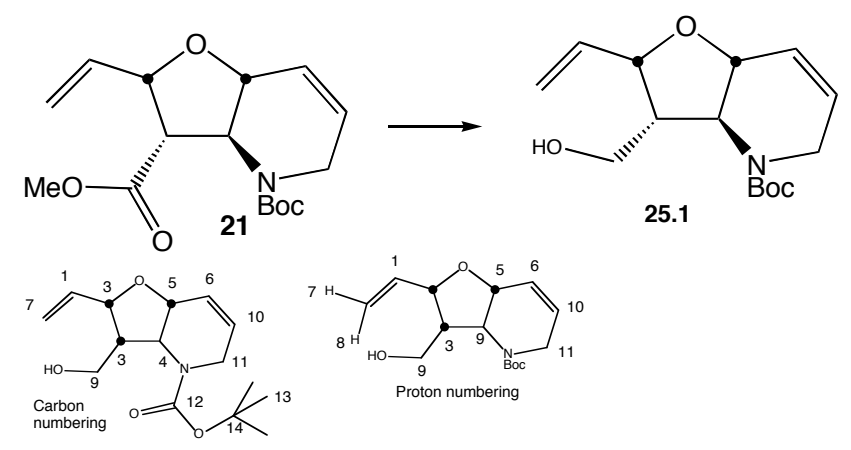

Alcohol 25.1: A solution of $\mathbf{2 1}(92 \mathrm{mg}, 0.297 \mathrm{mmol})$ in dry ethyl ether $(4 \mathrm{~mL})$ was added to a solution of lithium aluminum hydride $(45 \mathrm{mg}, 1.19 \mathrm{mmol})$ in dry ethyl ether $(1 \mathrm{~mL})$ at $0^{\circ} \mathrm{C}$ under inert atmosphere. After 1 hour, ethyl acetate was added and washed with $0.2 \mathrm{M} \mathrm{HCl}$. The aqueous layer was washed with ethyl acetate. The combined organic layers were washed with brine, dried over sodium sulfate, concentrated in vacuo. The crude product was chromatographed using 5:1 hexane:ethyl acetate $\left(\mathrm{R}_{\mathrm{F}}=0.23\right.$ in $25 \%$ ethyl acetate/hexane) to obtain $\mathbf{2 5 . 1}$ as a colorless film ( $34.9 \mathrm{mg}$, $42 \%$ yield).

Alternative procedure: To a cooled solution $\left(-78^{\circ} \mathrm{C}\right)$ of methyl ester $21(82 \mathrm{mg}, 0.267 \mathrm{mmol})$ in toluene $(2 \mathrm{~mL})$ was added DIBAL ( $1.5 \mathrm{M}$ solution in toluene, $0.89 \mathrm{~mL}, 1.33 \mathrm{mmol})$. After 10 minutes, the reaction was quenched with Rochelle's salt and allowed to warm up to room temperature and then was extracted with methylene chloride. The combined organic layers were washed with brine, dried over sodium sulfate, filtered and concentrated in vacuo. The crude product was chromatographed using $30 \%$ ethyl ether/hexane $\left(\mathrm{R}_{\mathrm{F}}=0.27\right.$ in $\left.50 \% \mathrm{EE} / \mathrm{Hex}\right)$ to to obtain $\mathbf{2 5 . 1}$ as a colorless film (47 mg, 62\% yield).

$[\alpha]_{25}\left(\mathrm{CH}_{2} \mathrm{Cl}_{2}\right)=-91^{\circ}$; IR (film, $\left.\mathrm{cm}^{-1}\right): 3455,2975,2926,1697,1476,1437,1367,1344,1248,1161,1036$, 927; ${ }^{1} \mathrm{H}$ NMR $\left(500 \mathrm{MHz}, \mathrm{CDCl}_{3}\right) \delta: 6.13\left(\mathrm{dd}, J=1.5 \mathrm{~Hz}, J=10.2 \mathrm{~Hz}, 1 \mathrm{H}, \mathrm{H}_{6}\right), 5.87\left(\mathrm{~m}, 1 \mathrm{H}, \mathrm{H}_{1}\right), 5.66$ (dddd, $\left.J=10.1 \mathrm{~Hz}, J=J=J=2.8 \mathrm{~Hz}, 1 \mathrm{H}, \mathrm{H}_{10}\right), 5.35\left(\mathrm{~d}, J_{1,8}=17.1 \mathrm{~Hz}, 1 \mathrm{H}, \mathrm{H}_{8}\right), 5.23\left(\mathrm{~d}, J_{1,7}=10.4 \mathrm{~Hz}\right.$, $\left.1 \mathrm{H}, \mathrm{H}_{7}\right), 4.72\left(\mathrm{t}, J=8.2 \mathrm{~Hz}, 1 \mathrm{H}, \mathrm{H}_{2}\right), 4.31\left(\mathrm{~d}, J=18.4 \mathrm{~Hz}, 1 \mathrm{H}, \mathrm{H}_{11}\right), 4.11\left(\mathrm{~m}, 1 \mathrm{H}, \mathrm{H}_{5}\right), 3.78\left(\mathrm{~m}, 2 \mathrm{H}, \mathrm{H}_{9}\right.$ and $\left.\mathrm{H}_{11}\right), 3.61\left(\mathrm{br} \mathrm{s}, 2 \mathrm{H}, \mathrm{H}_{3}\right.$ and $\left.\mathrm{H}_{9}\right), 2.94\left(\mathrm{t}, J=9.8 \mathrm{~Hz}, 1 \mathrm{H}, \mathrm{H}_{4}\right), 1.46(\mathrm{~s}, 9 \mathrm{H}, \mathrm{Boc}) ;{ }^{13} \mathrm{C}$ NMR $(125 \mathrm{MHz}$, $\left.\mathrm{CDCl}_{3}\right)$ \&: 155.0, 134.8, 127.7, 125.6, 118.1, 82.0, 81.0, 76.8, 63.7, 62.6, 47.6, 44.7, 28.4; HRMS (CI) Calcd for $\mathrm{C}_{15} \mathrm{H}_{23} \mathrm{NO}_{4}+\mathrm{H}: 282.1705$. Found: 282.1697.

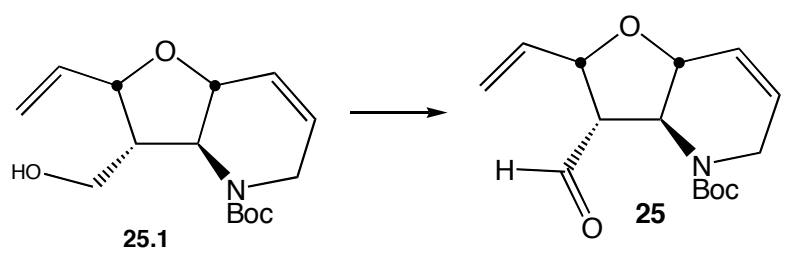

Aldehyde 25: To a solution of alcohol $25.1(153.4 \mathrm{mg}, 0.545 \mathrm{mmol})$ and pyridine $(88 \mu \mathrm{L}, 1.09 \mathrm{mmol})$ in methylene chloride at $0^{\circ} \mathrm{C}$ was added Dess-Martin reagent $(300 \mathrm{mg}, 0.709 \mathrm{mmol})$. After 1 hour, more Dess-Martin reagent $(46 \mathrm{mg}, 0.109 \mathrm{mmol})$ was added. After another hour, the reaction was warmed to room temperature. The reaction mixture was diluted with ethyl ether after 1 hour and extracted with water, saturated sodium bicarbonate, and sodium thiosulfate. The combined aqueous layers were washed with ethyl ether. The combined ether layers were dried over sodium sulfate and concentrated in vacuo to give the crude product. Purification by silica gel chromatography (10-20\% ethyl ether/hexane, $R_{F}=0.48$ in $50 \% \mathrm{EE} / \mathrm{Hx}$ ) afforded aldehyde 25 as a colorless oil (111 mg, 73\% yield). $[\alpha]_{\mathrm{D}}\left(\mathrm{CH}_{2} \mathrm{Cl}_{2}\right)=-24^{\circ}$; IR (film, $\left.\mathrm{cm}^{-1}\right): 2977,2843,1725,1693,1411,1368,1345,1240,1163,981,935$. ${ }^{1} \mathrm{H} \mathrm{NMR}\left(500 \mathrm{MHz}, \mathrm{CDCl}_{3}\right) \delta: 9.68(\mathrm{~d}, J=2.7 \mathrm{~Hz}, 1 \mathrm{H}), 6.18(\mathrm{~d}, J=10.2 \mathrm{~Hz}, 1 \mathrm{H}), 5.74(\mathrm{~m}, 2 \mathrm{H}), 5.37(\mathrm{~d}$, $J=17.0 \mathrm{~Hz}, 1 \mathrm{H}), 5.24(\mathrm{~d}, J=10.3 \mathrm{~Hz}, 1 \mathrm{H}), 4.91(\mathrm{dd}, J=7.7 \mathrm{~Hz}, J=10.2 \mathrm{~Hz}, 1 \mathrm{H}), 4.13(\mathrm{~m}, 2 \mathrm{H}), 3.96(\mathrm{dt}$, 
$J=2.8 \mathrm{~Hz}, J=10.7 \mathrm{~Hz}, 1 \mathrm{H}), 3.83(\mathrm{~m}, 1 \mathrm{H}), 3.50(\mathrm{dd}, J=11.1 \mathrm{~Hz}, J=8.9 \mathrm{~Hz}, 1 \mathrm{H}), 1.42(\mathrm{~s}, 9 \mathrm{H}, \mathrm{Boc}) ;{ }^{13} \mathrm{C}$ NMR $\left(125 \mathrm{MHz}, \mathrm{CDCl}_{3}\right.$ ) $\delta: 199.5,154.7,134.5,126.8,125.4,118.6,80.8,77.6,58.4,56.0,46.8,28.2$; HRMS (CI) Calcd for $\mathrm{C}_{15} \mathrm{H}_{21} \mathrm{O}_{4} \mathrm{~N}+\mathrm{H}: 280.1548$. Found: 280.1546.

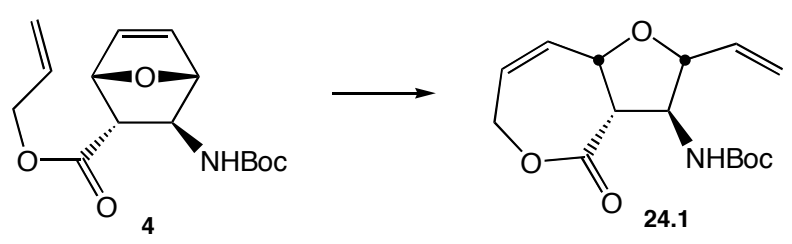

Bicyclic lactone 24.1: Argon was bubbled through a solution of 4 (200 mg, $0.677 \mathrm{mmol})$ in methylene chloride $(500 \mathrm{~mL}, 1.4 \mathrm{mM})$. Ethylene was then bubbled through and the Grubb's catalyst 6 (28 $\mathrm{mg}$, $0.0339 \mathrm{mmol}, 0.05 \mathrm{eq})$ was added. After 45 minutes, the ethylene source was removed, argon was bubbled through, the reaction was heated to reflux for 3 hours. More catalyst was added (10 mg, 0.012 mmol, $0.02 \mathrm{eq}$ ) and the reaction was refluxed for an additional hour. After the reaction cooled to room temperature, ethyl vinyl ether was added $(3 \mathrm{~mL})$ and the reaction was allowed to stir overnight. The reaction mixture was concentrated in vacuo and purified by silica gel chromatography $\left(5 \% \mathrm{EE} / \mathrm{CH}_{2} \mathrm{Cl}_{2}, \mathrm{R}_{\mathrm{F}}\right.$ $=0.24)$ two times to afford $\mathbf{2 4 . 1}$ as a pale brown film $(61.6 \mathrm{mg}, 31 \%)$.

$[\alpha]_{\mathrm{D}}\left(\mathrm{CH}_{2} \mathrm{Cl}_{2}\right)=-25^{\circ}$

IR (film, $\mathrm{cm}^{-1}$ ): 3336, 2979, 1732, 1522, 1404, 1367, 1297, 1244, 1170, 1046, 1024, 932, 868, 795, 732; ${ }^{1} \mathrm{H}$ NMR $\left(500 \mathrm{MHz}, \mathrm{d}_{8}\right.$-toluene, quintet $\left.=2.09,27^{\circ} \mathrm{C}\right) \delta: 5.86(\mathrm{~m}, 2 \mathrm{H}), 5.34(\mathrm{~m}, 1 \mathrm{H}), 5.18(\mathrm{~d}, J=17.3 \mathrm{~Hz}$, $1 \mathrm{H}), 4.98$ (d, J = 10.3 Hz, 1H), 4.69 (br s, 1H), 4.33 (br s, 1H), 4.29 (br s, 1H), 4.23 (br s, 1H), 3.72 (br s, 1H), 3.44 (br s, 1H), 1.40 (s, 9H, Boc); ${ }^{1} \mathrm{H}$ NMR (500 MHz, d d -toluene, quintet = $2.09 \mathrm{ppm}, 80^{\circ} \mathrm{C}$ ) $\delta: 5.85$ $(\mathrm{m}, 2 \mathrm{H}), 5.43(\mathrm{~m}, 1 \mathrm{H}), 5.18(\mathrm{~d}, J=17.3 \mathrm{~Hz}, 1 \mathrm{H}), 4.97(\mathrm{~d}, J=10.4 \mathrm{~Hz}, 1 \mathrm{H}), 4.58$ (br s, $1 \mathrm{H}), 4.37$ (br s, 1H), 4.24 (br s, 1H), 4.08 (br s, $1 \mathrm{H}), 3.90$ (dd, $J=6.3 \mathrm{~Hz}, J=13.6 \mathrm{~Hz}, 1 \mathrm{H}), 3.58$ (dd, $J=7.2 \mathrm{~Hz}, J=13.6$ $\mathrm{Hz}, 1 \mathrm{H}), 3.34$ (br s, 1H), 1.40 (s, 9H, Boc); ${ }^{13} \mathrm{C} \mathrm{NMR}\left(125 \mathrm{MHz}, \mathrm{d}_{8}\right.$-toluene, septet = $\left.20.4 \mathrm{ppm}\right) \delta: 171.0$, 155.5, 137.4, 136.6, 126.4, 117.3, 83.0, 79.4, 75.8, 61.0, 60.1, 53.2, 28.4; HRMS Calcd for $\mathrm{C}_{15} \mathrm{H}_{21} \mathrm{NO}_{5}+\mathrm{Na}: 318.1317$. Found: 318.1319 .
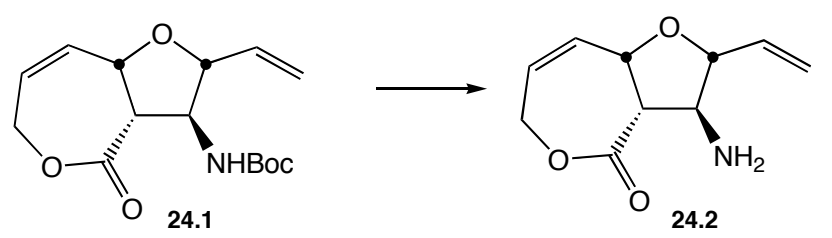

Primary amine 24.2: To a solution of $\mathbf{2 4 . 1}(92.6 \mathrm{mg}, 0.314 \mathrm{mmol})$ in methylene chloride $(1 \mathrm{~mL})$ was added TFA $(1 \mathrm{~mL})$ at room temperature. After 30 minutes, the reaction was concentrated and then basified with $1 \mathrm{~N} \mathrm{KHCO}_{3}$ to $\mathrm{pH} 8$. The aqueous layer was extracted several times with ethyl acetate. The combined ethyl acetate layers were dried over sodium sulfate and concentrated. The amine was then dissolved in methanol and treated with activated charcoal to remove the colored impurities. After filtration through celite, the methanol was removed in vacuo to afford amine $\mathbf{2 4 . 2}$ as a yellow oil in quantitative yield.

$[\alpha]_{\mathrm{D}}(\mathrm{MeOH})=+5^{\circ}$

IR (film, $\left.\mathrm{cm}^{-1}\right): 3442,1680,1554,1430,1204,1182,1137,1023 ;{ }^{1} \mathrm{H} \mathrm{NMR}\left(500 \mathrm{MHz}, \mathrm{CDCl}_{3}\right) \delta: 6.21$ (br $\mathrm{d}, J=10.6 \mathrm{~Hz}, 1 \mathrm{H}), 6.11(\mathrm{~m}, 1 \mathrm{H}), 5.95(\mathrm{ddd}, J=7.6 \mathrm{~Hz}, J=10.3 \mathrm{~Hz}, J=17.9 \mathrm{~Hz}, 1 \mathrm{H}), 5.40(\mathrm{ddd}, J=0.9$ $\mathrm{Hz}, J=1.5 \mathrm{~Hz}, J=17.2,1 \mathrm{H}), 5.29(\mathrm{ddd}, J=0.7 \mathrm{~Hz}, J=1.5 \mathrm{~Hz}, J=10.3 \mathrm{~Hz}, 1 \mathrm{H}), 4.85(\mathrm{dddd}, J=J=J=$ $2.2 \mathrm{~Hz}, J=8.6 \mathrm{~Hz}, 1 \mathrm{H}), 4.67(\mathrm{~m}, 1 \mathrm{H}), 4.37(\mathrm{ddd}, J=1.2 \mathrm{~Hz}, J=7.3 \mathrm{~Hz}, J=13.4 \mathrm{~Hz}, 1 \mathrm{H}), 3.94(\mathrm{dd}, J=$ 
$4.5 \mathrm{~Hz}, J=6.9 \mathrm{~Hz}, 1 \mathrm{H}), 3.85(\mathrm{~m}, 1 \mathrm{H}), 3.22(\mathrm{dd}, J=4.5 \mathrm{~Hz}, J=8.6 \mathrm{~Hz}, 1 \mathrm{H}), 1.67\left(\mathrm{br} \mathrm{s}, 2 \mathrm{H}, \mathrm{N} H_{2}\right) ;{ }^{13} \mathrm{C}$

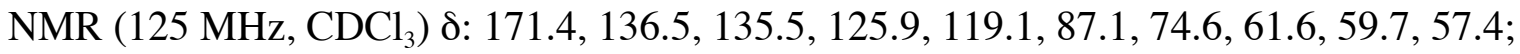

HRMS Calcd for $\mathrm{C}_{10} \mathrm{H}_{13} \mathrm{NO}_{3}+\mathrm{H}$ : 196.0974. Found: 196.0983.
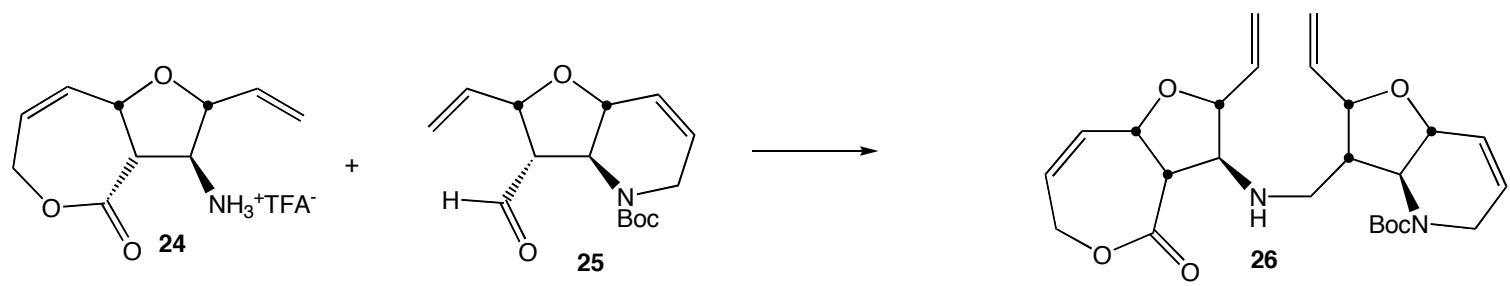

Tetracyclic secondary amine 26: Sodium triacetoxyborohydride (50 mg, $0.237 \mathrm{mmol}$ ) and glacial acetic acid (4 drops from 22G needle) was added to a solution of aldehyde 25 (47 $\mathrm{mg}, 0.169 \mathrm{mmol}$ ) and amine 24 (as the TFA salt, $52 \mathrm{mg}, 0.0169 \mathrm{mmol}$ ) in methylene chloride $(2 \mathrm{~mL})$. After 24 hours, saturated sodium bicarbonate was added and extracted with ethyl acetate several times. The combined organic extracts were dried over $\mathrm{Na}_{2} \mathrm{SO}_{4}$, filtered and concentrated. The crude product was purified by silica gel chromatography (50\% EtOAc/Hx) to afford secondary amine $\mathbf{2 6}(70 \mathrm{mg}, 90 \%)$ as a pale yellow oil.

$[\alpha]_{\mathrm{D}}(\mathrm{MeOH})=-56^{\circ}$

IR (film, $\mathrm{cm}^{-1}$ ): 3354, 2922, 2852, 1735, 1693, 1436, 1366, 1259, 1169, 1140, 1073, 1053, 992, 928; ${ }^{1} \mathrm{H}$

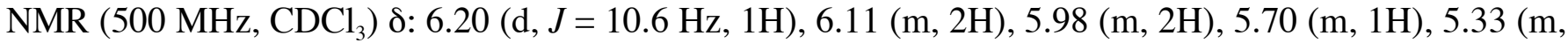
$2 \mathrm{H}), 5.23(\mathrm{t}, J=11.0,2 \mathrm{H}), 4.70(\mathrm{~m}, 3 \mathrm{H}), 4.34(\mathrm{~m}, 2 \mathrm{H}), 4.11(\mathrm{~d}, J=10.5 \mathrm{~Hz}, 1 \mathrm{H}), 3.86(\mathrm{~m}, 1 \mathrm{H}), 3.82(\mathrm{dd}$, $J=2.2 \mathrm{~Hz}, J=5.4 \mathrm{~Hz}, 1 \mathrm{H}), 3.69(\mathrm{~m}, 1 \mathrm{H}), 3.48(\mathrm{~m}, 1 \mathrm{H}), 3.34(\mathrm{~d}, J=7.9 \mathrm{~Hz}, 1 \mathrm{H}), 2.91(\mathrm{dd}, J=4.4 \mathrm{~Hz}, J=$

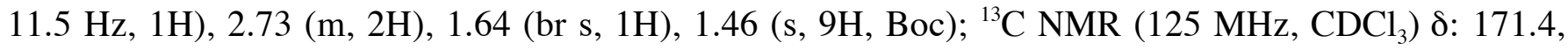
153.7, 136.3, 135.5, 134.8, 127.7, 126.1, 126.0, 117.9, 117.8, 85.9, 82.2, 80.1, 77.2, 76.2, 75.3, 67.3, 63.1, 61.4, 53.6, 48.2, 48.0, 44.2, 28.5; HRMS (CI) Calcd for $\mathrm{C}_{25} \mathrm{H}_{34} \mathrm{O}_{6} \mathrm{~N}_{2}+\mathrm{H}$ : 459.2495, Found: 459.2504.
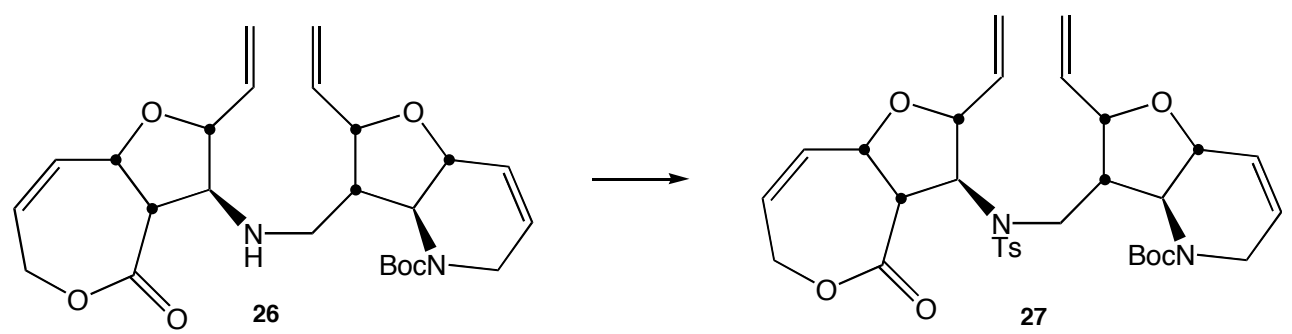

Tetracyclic tosyl-amine 27: A solution of amine 26 (11 mg, $0.0240 \mathrm{mmol}$ ), DMAP (one small crystal), tosyl chloride $(6.8 \mathrm{mg}, 0.0360$, recrystallized from Pet. Ether) and triethylamine $(7 \mu \mathrm{L}, 0.048 \mathrm{mmol})$ in methylene chloride $(0.1 \mathrm{~mL})$ was stirred for 48 hours at room temperature. $\mathrm{HCl}$ solution $(0.2 \mathrm{~N})$ was added and the reaction mixture was extracted with methylene chloride. The combined methylene chloride layers were dried over $\mathrm{Na}_{2} \mathrm{SO}_{4}$, filtered, and concentrated in vacuo. Purification by silica gel chromatography (25\% EtOAc/Hexane) affored $27(12.1 \mathrm{mg}, 82 \%)$ as a clear film.

$[\alpha]_{\mathrm{D}}\left(\mathrm{CH}_{2} \mathrm{Cl}_{2}\right)=-71^{\circ}$

IR (film, $\mathrm{cm}^{-1}$ ): 2924, 2853, 1738, 1688, 1598, 1452, 1368, 1345, 1286, 1236, 1162, 1030, 932; ${ }^{1} \mathrm{H}$ NMR

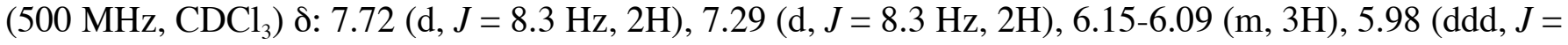
$6.9 \mathrm{~Hz}, J=10.4 \mathrm{~Hz}, J=17.1 \mathrm{~Hz}, 1 \mathrm{H}), 5.76(J=7.5 \mathrm{~Hz}, J=10.3 \mathrm{~Hz}, J=17.4 \mathrm{~Hz}, 1 \mathrm{H}), 5.65(\mathrm{~m}, 1 \mathrm{H}), 5.33$ $(\mathrm{m}, 1 \mathrm{H}), 5.24(\mathrm{~d}, J=10.4 \mathrm{~Hz}, 1 \mathrm{H}), 4.99-4.83(\mathrm{~m}, 5 \mathrm{H}), 4.75(\mathrm{dd}, J=J=7.8 \mathrm{~Hz}, 1 \mathrm{H}), 4.38-4.28(\mathrm{~m}, 4 \mathrm{H})$, $4.19(\mathrm{~m}, 1 \mathrm{H}), 4.06(\mathrm{~m}, 1 \mathrm{H}), 3.74(\mathrm{~d}, J=17.3 \mathrm{~Hz}, 1 \mathrm{H}), 3.52-3.57(\mathrm{~m}, 2 \mathrm{H}), 2.95(\mathrm{dd}, J=J=10.0 \mathrm{~Hz}), 2.42$

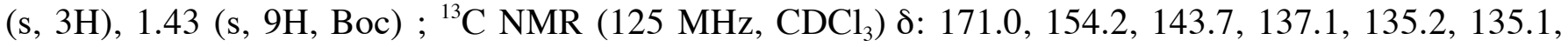


135.0, 129.7, 128.1, 127.9, 126.9, 126.1, 118.7, 118.2, 81.8, 80.3, 77.2, 76.1, 74.8, 65.2, 64.9, 61.2, 51.5, 48.8, 48.4, 41.2, 28.4, 21.5; HRMS (ES) Calcd for $\mathrm{C}_{32} \mathrm{H}_{40} \mathrm{O}_{8} \mathrm{~N}_{2} \mathrm{~S}+\mathrm{Na}$ : 635.2403. Found: 635.2403.
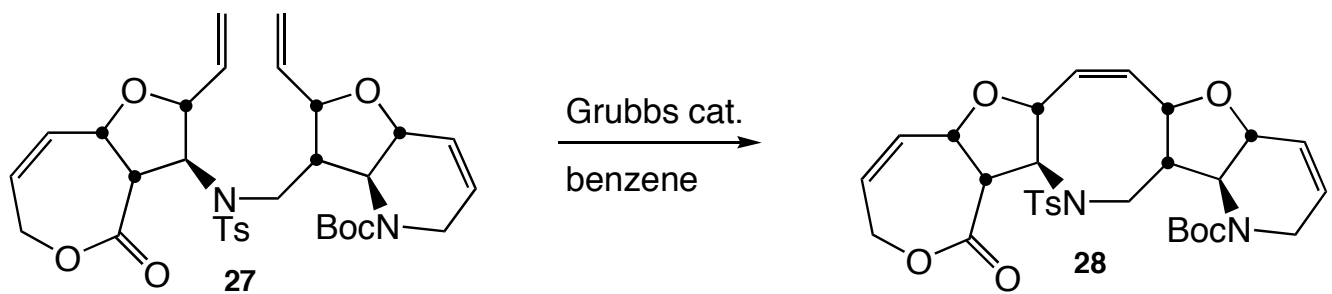

Pentacycle 28: Argon was bubbled through a solution of $27(20 \mathrm{mg}, 0.0326 \mathrm{mmol})$ in benzene $(0.5 \mathrm{mM}$, $70 \mathrm{~mL}$ ) for 30 minutes. Grubbs catalyst $6(3 \mathrm{mg}, 0.00353 \mathrm{mmol}, 11 \mathrm{~mol} \%)$ was added and the reaction mixture was heated to $80^{\circ} \mathrm{C}$ for 3 days while adding $3 \mathrm{mg}$ of catalyst every 24 hours. The reaction was concentrated and diluted with methylene chloride $(5 \mathrm{~mL})$. To this solution was added tris(hydroxymethyl)phosphine $(15 \mathrm{mg}, 0.012 \mathrm{mmol})$ and triethylamine $(0.032 \mathrm{~mL}, 0.024 \mathrm{mmol})$ to make the ruthenium catalyst water soluble. This was solution was vigorously stirred for 15 minutes, then stirred with water for an additional 20 minutes. The aqueous layer was washed with methylene chloride, and the combined methylene chloride layers were dried over sodium sulfate, filtered and concentrated. The crude product was subject to silica gel chromatography using $2 \%$ ethyl ether/ methylene chloride as the eluent to obtain 28 as a colorless film ( $5 \mathrm{mg}, 26 \%$ yield).

$\mathrm{R}_{\mathrm{F}}=0.17$ in $4 \% \mathrm{EE} / \mathrm{DCM}$

$[\alpha]_{\mathrm{D}}\left(\mathrm{CH}_{2} \mathrm{Cl}_{2}\right):-129^{\circ}$

IR (film, cm cm $^{-1}$ : 2968, 2924, 2854, 1732 (s), 1694 (s), 1454, 1395, 1367, 1341, 1290, 1236, 1161 (s), 1095 , 1066, 1000; ${ }^{1} \mathrm{H}$ NMR $\left(500 \mathrm{MHz}, \mathrm{CDCl}_{3}\right) \delta: 7.70(\mathrm{~d}, J=8.3 \mathrm{~Hz}, 2 \mathrm{H}), 7.28(\mathrm{~d}, J=8.0 \mathrm{~Hz}, 2 \mathrm{H}), 6.16(\mathrm{~m}$, 2H), $6.09(\mathrm{~m}, 1 \mathrm{H}), 5.78(\mathrm{ddd}, J=2.1 \mathrm{~Hz}, J=6.6 \mathrm{~Hz}, J=11.7 \mathrm{~Hz}, 1 \mathrm{H}), 5.72(\mathrm{ddd}, J=1.2 \mathrm{~Hz}, J=5.5 \mathrm{~Hz}$, $J=11.7 \mathrm{~Hz}, 1 \mathrm{H}), 5.65(\mathrm{~m}, 1 \mathrm{H}), 5.27(\mathrm{ddd}, J=1.9 \mathrm{~Hz}, J=5.4 \mathrm{~Hz}, J=8.1 \mathrm{~Hz}, 1 \mathrm{H}), 4.90(\mathrm{~m}, 1 \mathrm{H}), 4.63$ 4.59 (m, 2H), 4.41 (dd, $J=J=7.3 \mathrm{~Hz}, 1 \mathrm{H}), 4.37-4.28(\mathrm{~m}, 4 \mathrm{H}), 4.19$ (dd, $J=4.8 \mathrm{~Hz}, J=8.4 \mathrm{~Hz}, 2 \mathrm{H}), 3.72$ $(\mathrm{ddd}, J=3.1 \mathrm{~Hz}, J=5.7 \mathrm{~Hz}, J=18.5 \mathrm{~Hz}, 1 \mathrm{H}), 2.90(\mathrm{dd}, J=11.0 \mathrm{~Hz}, J=15.1 \mathrm{~Hz}, 1 \mathrm{H}), 2.77(\mathrm{dd}, J=9.6$

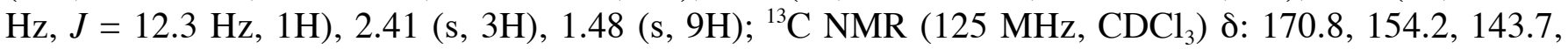
$137.4,135.4,133.5,129.9,129.6,129.4,126.6,126.0,125.8,81.5,80.7,78.8,76.6,76.4,72.1,62.5$, 61.3, 53.7, 50.8, 49.5, 48.1, 28.3, 21.5; HRMS (ES) Calcd for $\mathrm{C}_{30} \mathrm{H}_{36} \mathrm{O}_{8} \mathrm{~N}_{2} \mathrm{~S}+\mathrm{Na}$ : 607.2090. Found: 607.2109 .

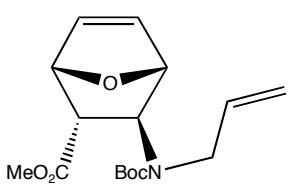

10

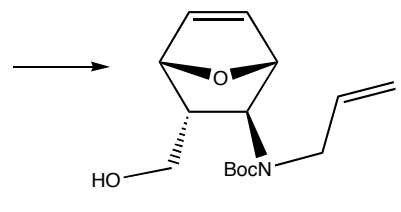

29

Alcohol 29: A solution of $\mathbf{1 0}(109.5 \mathrm{mg}, 0.354 \mathrm{mmol})$ in dry ethyl ether (1 mL) was added to a solution of lithium aluminum hydride $(27 \mathrm{mg}, 0.708 \mathrm{mmol})$ in dry ethyl ether $(1 \mathrm{~mL})$ at $0^{\circ} \mathrm{C}$ under inert atmosphere. After 1 hour, ethyl acetate was added and washed with $0.2 \mathrm{M} \mathrm{HCl}$. Then the aqueous layer was washed with ethyl acetate. The combined organic layers were washed with brine, dried over sodium sulfate, concentrated in vacuo. The product was chromatographed using 4:1:1 hexane:ethyl ether:ethyl acetate $\left(\mathrm{R}_{\mathrm{F}}\right.$ $=0.29$ in 2:1:1 hexane: ethyl ether: ethyl acetate) to obtain 29 as a colorless film $(82.6 \mathrm{mg}, 83 \%$ yield $)$. IR (film, cm ${ }^{-1}$ ): 3426, 2977, 2932, 2875, 1688, 1661, 1478, 1455, 1409, 1366, 1335, 1276, 1247, 1169 ,

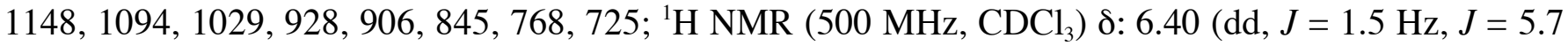


$\mathrm{Hz}, 1 \mathrm{H}), 6.34(\mathrm{~d}, J=5.6,1 \mathrm{H}), 5.88(\mathrm{~m}, 1 \mathrm{H}), 5.12(\mathrm{~m}, 2 \mathrm{H}), 4.93(\mathrm{~s}, 1 \mathrm{H}), 4.87(\mathrm{~s}, 1 \mathrm{H}), 3.96(\mathrm{~d}, J=4.9 \mathrm{~Hz}$, $2 \mathrm{H}), 3.78(\mathrm{~s}, 1 \mathrm{H}), 3.59(\mathrm{~d}, J=7.8 \mathrm{~Hz}, 1 \mathrm{H}), 3.18(\mathrm{t}, J=9.2 \mathrm{~Hz}, 1 \mathrm{H}), 2.04(\mathrm{br} \mathrm{s}, 1 \mathrm{H}), 1.44(\mathrm{~s}, 9 \mathrm{H}, \mathrm{Boc}) ;{ }^{13} \mathrm{C}$ NMR $\left(125 \mathrm{MHz}, \mathrm{CDCl}_{3}\right) \delta: 156.9,135.9,135.7,135.2,115.2,81.3,80.7,78.5,64.0,59.8,49.8,44.8$, 28.3; HRMS Calcd for $\mathrm{C}_{15} \mathrm{H}_{23} \mathrm{O}_{4} \mathrm{NNa}$ : 304.1524, Found: 304.1527.
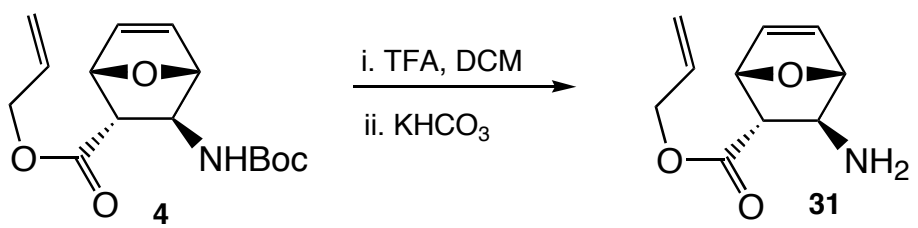

Primary amine 31: To a solution of allyl ester 4 ( $29 \mathrm{mg}, 0.0981 \mathrm{mmol}$ ) in methylene chloride $(0.5 \mathrm{~mL})$ was added TFA $(0.2 \mathrm{~mL})$. After 30 minutes, the reaction mixture was concentrated in vacuo and basified to $\mathrm{pH} 8$ with $1 \mathrm{~N} \mathrm{HCO}_{3}$. The aqueous layer was extracted with ethyl acetate several times. The combined organic layers were dried over sodium sulfate, filtered, and concentrated in vacuo to afford $\mathbf{3 1}$ as a colorless oil (19 mg, quant.).

$[\alpha]_{\mathrm{D}}(\mathrm{MeOH}):-110^{\circ}$

IR (film, $\mathrm{cm}^{-1}$ ): 3354 (br), 2930, 1732 (s), 1682 (s), 1651, 1427, 1316, 1203, 1134, 1042, 992, 903, 859, 835, 800, 722, 697; ${ }^{1} \mathrm{H}$ NMR $\left(500 \mathrm{MHz}, \mathrm{CDCl}_{3}\right)$ $\delta: 6.44(\mathrm{~d}, J=5.9 \mathrm{~Hz}, 1 \mathrm{H}), 6.38(\mathrm{~d}, J=5.9 \mathrm{~Hz}, 1 \mathrm{H}), 5.87$ $(\mathrm{m}, 1 \mathrm{H}), 5.30(\mathrm{dd}, J=1.3 \mathrm{~Hz}, J=17.2 \mathrm{~Hz}, 1 \mathrm{H}), 5.25(\mathrm{dd}, J=1.0 \mathrm{~Hz}, J=10.4 \mathrm{~Hz}, 1 \mathrm{H}), 5.17(\mathrm{~d}, J=4.5$ $\mathrm{Hz}, 1 \mathrm{H}), 4.83(\mathrm{~s}, 1 \mathrm{H}), 4.56(\mathrm{~d}, J=5.8 \mathrm{~Hz}, 2 \mathrm{H}), 4.25$ (br s, 2H, NH $) 3.47(\mathrm{br} \mathrm{s}, 1 \mathrm{H}), 2.90(\mathrm{~m}, 1 \mathrm{H}) ;{ }^{13} \mathrm{C}$ NMR $\left(125 \mathrm{MHz}, \mathrm{CDCl}_{3}\right.$ ) $\delta: 170.5,136.2,135.5,132.1,119.3,85.4,79.4,66.1,55.4,53.6$; HRMS (ES) Calcd for $\mathrm{C}_{10} \mathrm{H}_{13} \mathrm{O}_{3} \mathrm{~N}+\mathrm{Na}$ : 196.0974. Found: 196.0980.
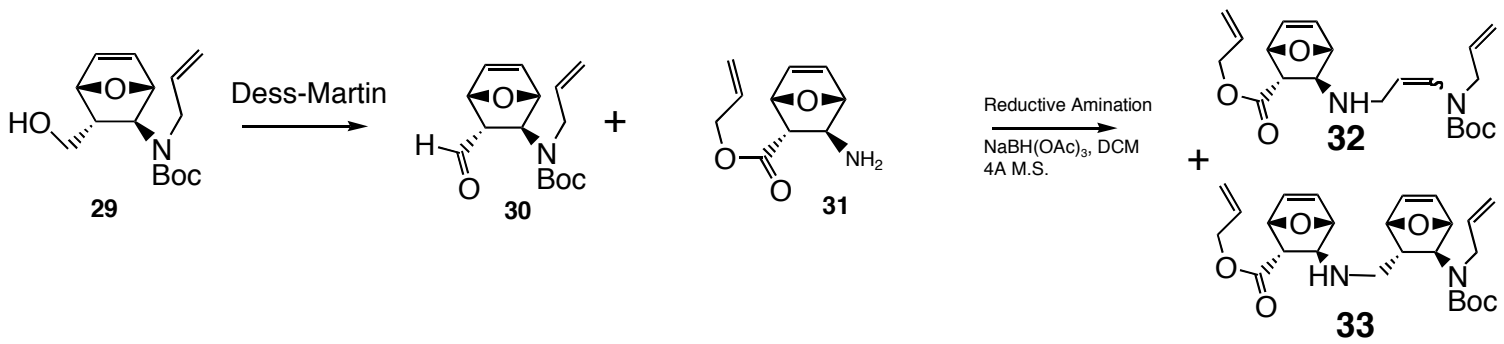

Preparation of mixture of 32 and 33: To a solution of alcohol 29 (30 $\mathrm{mg}, 0.107 \mathrm{mmol}$ ) and sodium bicarbonate $(45 \mathrm{mg}, 0.533 \mathrm{mmol})$ in methylene chloride $(1 \mathrm{~mL})$ was added Dess-Martin periodinane (68 $\mathrm{mg}, 0.160 \mathrm{mmol}$ ). After 1.5 hours, the reaction was allowed to warm to room temperature, where an additional Dess-Martin periodinane $(16 \mathrm{mg}, 0.038 \mathrm{mmol})$ was added. The reaction was diluted with ether after 45 minutes and washed with water, saturated sodium bicarbonate solution, and saturated sodium thiosulfate pentahydrate. The combined aqueous layers were washed with ether. The combined ether layers were dried over sodium sulfate, filtered, and concentrated to afford crude aldehyde $\mathbf{3 0 .}$

To a solution of amine 31 ( $21 \mathrm{mg}, 0.107 \mathrm{mmol}$ ) in methylene chloride was added the crude aldehyde (as a solution in methylene chloride) immediately followed by the addition of sodium triacetoxyborohydride (32 $\mathrm{mg}, 0.149 \mathrm{mmol}$ ). After 24 hours, saturated sodium bicarbonate solution was added and the aqueous layer was washed with ethyl acetate several times. The combined ethyl acetate layers were dried over sodium sulfate, filtered and concentrated in vacuo. The crude product that was subJected to silica gel chromatography using 10\% Ace/Hx to afford a mixture of 2 inseparable amines 32 and $\mathbf{3 3}$ (29.1 mg). A very small amount of relatively pure $\mathbf{3 3}$ was obtained for characterization: clear film; $[\alpha]_{\mathrm{D}}\left(\mathrm{CH}_{2} \mathrm{Cl}_{2}\right):-60^{\circ}$ 
IR (film, cm $\mathrm{cm}^{-1}$ ): 3299, 2976, 2930, 1732 (s), 1684 (s), 1454, 1408, 1366, 1334, 1275, 1246, 1171 (s), 993 , 905; ${ }^{1} \mathrm{H}$ NMR $\left(500 \mathrm{MHz}, \mathrm{CDCl}_{3}\right) \delta: 6.43(\mathrm{dd}, J=1.9 \mathrm{~Hz}, J=5.8 \mathrm{~Hz}, 1 \mathrm{H}), 6.40(\mathrm{~m}, 2 \mathrm{H}), 6.36(\mathrm{dd}, J=1.3$ $\mathrm{Hz}, J=5.8 \mathrm{~Hz}, 1 \mathrm{H}), 5.89$ (dddd, $J=J=5.8 \mathrm{~Hz}, J=10.6 \mathrm{~Hz}, J=16.3 \mathrm{~Hz}, 1 \mathrm{H}), 5.31$ (ddd, $J=J=J=1.4$ $\mathrm{Hz}, J=17.2 \mathrm{~Hz}, 1 \mathrm{H}), 5.25(\mathrm{dd}, J=1.2 \mathrm{~Hz}, J=10.5 \mathrm{~Hz}, 1 \mathrm{H}), 5.16-5.11(\mathrm{~m}, 2 \mathrm{H}), 5.10(\mathrm{dd}, J=1.5 \mathrm{~Hz}, J$ $=10.3 \mathrm{~Hz}, 1 \mathrm{H}), 4.92(\mathrm{~d}, J=3.3 \mathrm{~Hz}, 1 \mathrm{H}), 4.81(\mathrm{~s}, 1 \mathrm{H}), 4.74($ br s, $1 \mathrm{H}), 4.55(\mathrm{~m}, 2 \mathrm{H}), 3.95(\mathrm{~m}, 3 \mathrm{H}), 3.06(\mathrm{~s}$, $1 \mathrm{H}), 2.73(\mathrm{~s}, 1 \mathrm{H}), 2.60(\mathrm{br} \mathrm{s}, 2 \mathrm{H}), 2.12(\mathrm{~s}, 1 \mathrm{H}), 1.59$ (br s, 1H, NH), 1.45 (s, 9H; HRMS (ES) Calcd for $\mathrm{C}_{25} \mathrm{H}_{34} \mathrm{O}_{6} \mathrm{~N}_{2}+\mathrm{Na}: 459.2495$. Found: 459.2495.

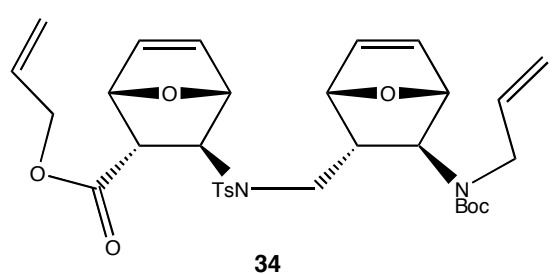

Sulfonamide 34: Tosyl chloride (19 mg, $0.0989 \mathrm{mmol})$, DMAP (2 mg), and triethylamine (28 $\mu \mathrm{L}, 0.198$ mmol) was added to a solution of the mixture of amines (32 and 33, $29.1 \mathrm{mg})$ in methylene chloride $(0.2$ $\mathrm{mL}$ ) and stirred for 24 hours at room temperature. The reaction mixture was diluted with methylene chloride and extracted with water. The water layer was extracted with methylene chloride $(3 \mathrm{x} 5 \mathrm{~mL})$. The combined organic layer was washed with brine, dried over sodium sulfate, filtered, and concentrated in vасио. The crude product was chromatographed using $30 \% \mathrm{EE} / \mathrm{Hx}$ as the eluent to afford the tosylated amine of $\mathbf{3 2}(7.7 \mathrm{mg})$ and the desired tosylated amine $\mathbf{3 4}(23.7 \mathrm{mg}, 36 \%$ yield over 3 steps beginning with the alcohol) as a clear film.

$\mathrm{R}_{\mathrm{F}}=0.20$ in $50 \% \mathrm{EE} / \mathrm{Hx}$

$[\alpha]_{\mathrm{D}}\left(\mathrm{CH}_{2} \mathrm{Cl}_{2}\right):-77^{\circ}$

IR (film, $\mathrm{cm}^{-1}$ ): 3082, 2976, 2930, 1737, 1683 (s), 1598, 1451, 1407, 1366, 1338, 1273, 1244, 1164 (s), 1101, 1019, 994, 908, 858; ${ }^{1} \mathrm{H}$ NMR $\left(500 \mathrm{MHz}_{,} \mathrm{CDCl}_{3}\right) \delta: 7.61(\mathrm{~d}, J=8.2 \mathrm{~Hz}, 2 \mathrm{H}), 7.22(\mathrm{~d}, J=8.0 \mathrm{~Hz}$, $2 \mathrm{H}), 6.74(\mathrm{~d}, J=5.5 \mathrm{~Hz}, 1 \mathrm{H}), 6.45(\mathrm{~m}, 2 \mathrm{H}), 6.25(\mathrm{dd}, J=1.1 \mathrm{~Hz}, J=5.8 \mathrm{~Hz}, 1 \mathrm{H}), 5.89(\mathrm{~m}, 1 \mathrm{H}), 5.76(\mathrm{~m}$, $1 \mathrm{H}), 5.24(\mathrm{dd}, J=1.3 \mathrm{~Hz}, J=17.2 \mathrm{~Hz}, 1 \mathrm{H}), 5.22(\mathrm{dd}, J=0.8 \mathrm{~Hz}, J=10.4,1 \mathrm{H}), 5.16-5.12(\mathrm{~m}, 2 \mathrm{H}), 5.07$ $(\mathrm{dd}, J=1.1 \mathrm{~Hz}, J=10.3 \mathrm{~Hz}, 1 \mathrm{H}), 4.97(\mathrm{~d}, J=4.5 \mathrm{~Hz}, 1 \mathrm{H}), 4.86(\mathrm{~s}, 1 \mathrm{H}), 4.75(\mathrm{~s}, 1 \mathrm{H}), 4.43-4.34(\mathrm{~m}, 2 \mathrm{H})$, $4.31(\mathrm{~s}, 1 \mathrm{H}), 3.92(\mathrm{~s}, 2 \mathrm{H}), 3.81(\mathrm{~s}, 1 \mathrm{H}), 3.47(\mathrm{~d}, J=15.2 \mathrm{~Hz}, 1 \mathrm{H}), 3.05(\mathrm{~m}, 1 \mathrm{H}), 2.78(\mathrm{t}, J=4.1 \mathrm{~Hz}, 1 \mathrm{H})$,

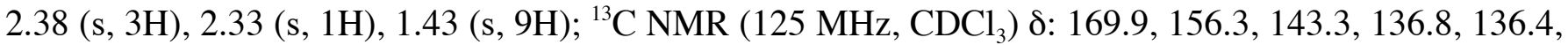
136.3, 135.9, 135.4, 131.5, 129.6, 127.4, 118.6, 115.2, 84.7, 81.8, 80.0, 79.7, 78.8, 65.5, 60.8, 59.6, 47.0, 46.1, 45.8, 44.8, 28.4, 21.4; HRMS (ES) Calcd for $\mathrm{C}_{32} \mathrm{H}_{40} \mathrm{O}_{8} \mathrm{~N}_{2} \mathrm{~S}+\mathrm{Na}$ : 635.2403. Found: 635.2420.

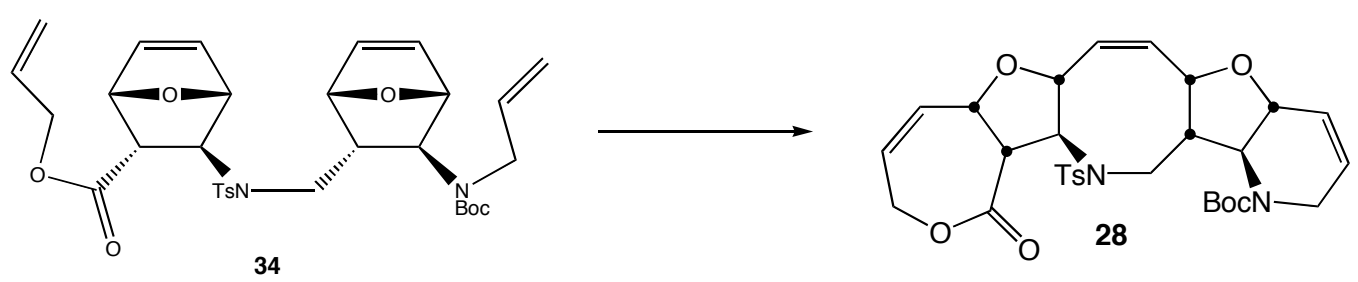

Pentacycle 28: Argon was bubbled through a solution of $\mathbf{3 4}(5 \mathrm{mg}, 0.0082 \mathrm{mmol})$ in methylene chloride $(0.5 \mathrm{mM}, 16 \mathrm{~mL})$ for 30 minutes. Grubbs catalyst $6(3 \mathrm{mg}, 0.00353 \mathrm{mmol}, 43 \mathrm{~mol} \%)$ was added and the reaction mixture was heated to reflux. More Grubbs catalyst $(4 \mathrm{mg}$ ) was added over 24 hours. (The total amount of catalyst used was $7 \mathrm{mg}, 100 \mathrm{~mol} \%$.) The reaction was concentrated and diluted with methylene chloride $(5 \mathrm{~mL})$. To this solution was added tris(hydroxymethyl)phosphine ( $30 \mathrm{mg}, 0.24 \mathrm{mmol}$, $29 \mathrm{eq})$ and triethylamine $(0.032 \mathrm{~mL}, 0.024 \mathrm{mmol})$. This was solution was vigorously stirred for 15 
minutes, then stirred with water for an additional 20 minutes. The aqueous layer was washed with methylene chloride, and the combined methylene chloride layers were dried over sodium sulfate, filtered and concentrated. The crude product was subJect to silica gel chromatography using $2-4 \%$ ethyl ether/ methylene chloride as the eluent to obtain 28 as a colorless film $(0.5 \mathrm{mg}, 10 \%$ yield $)$. 


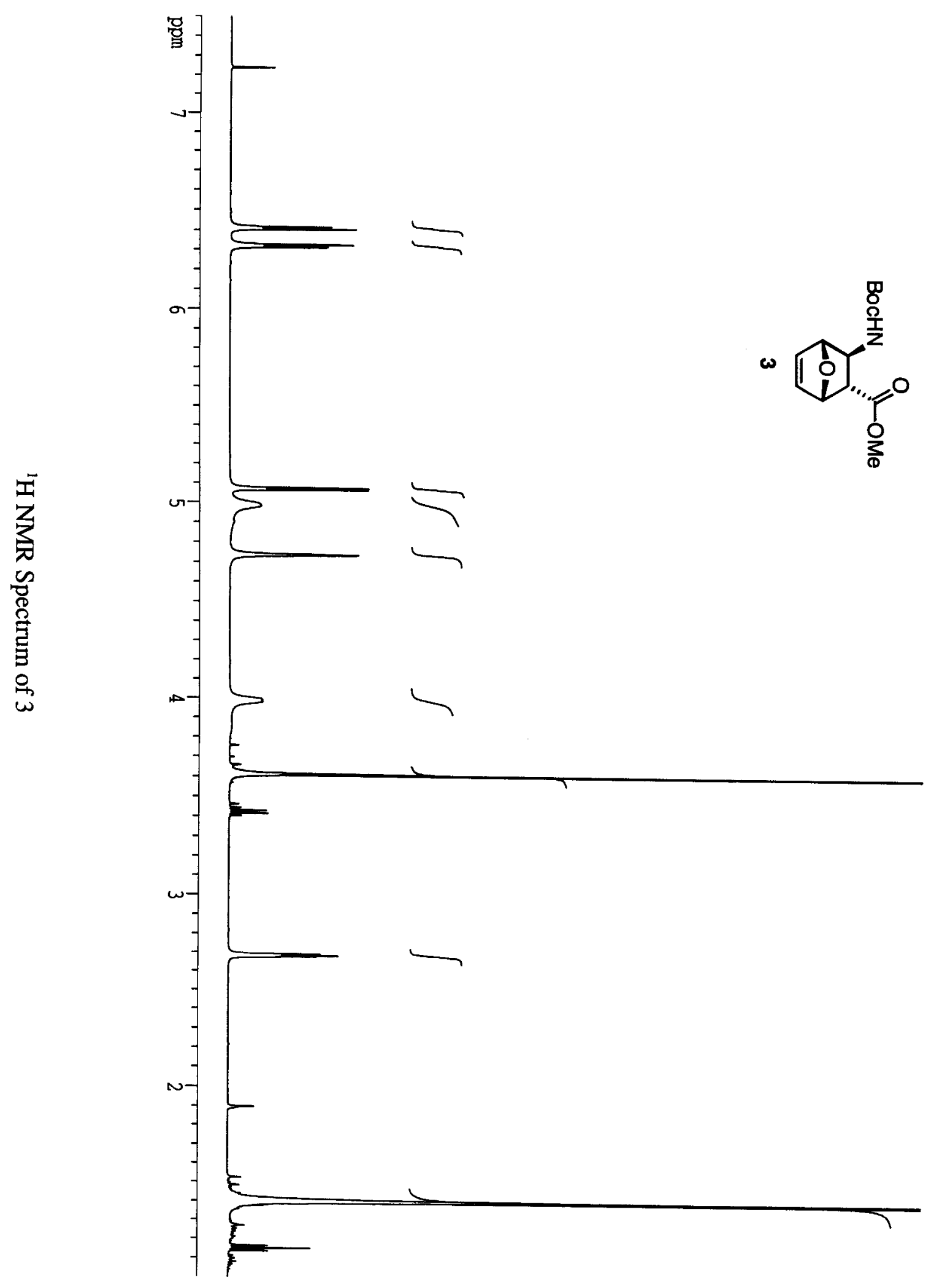




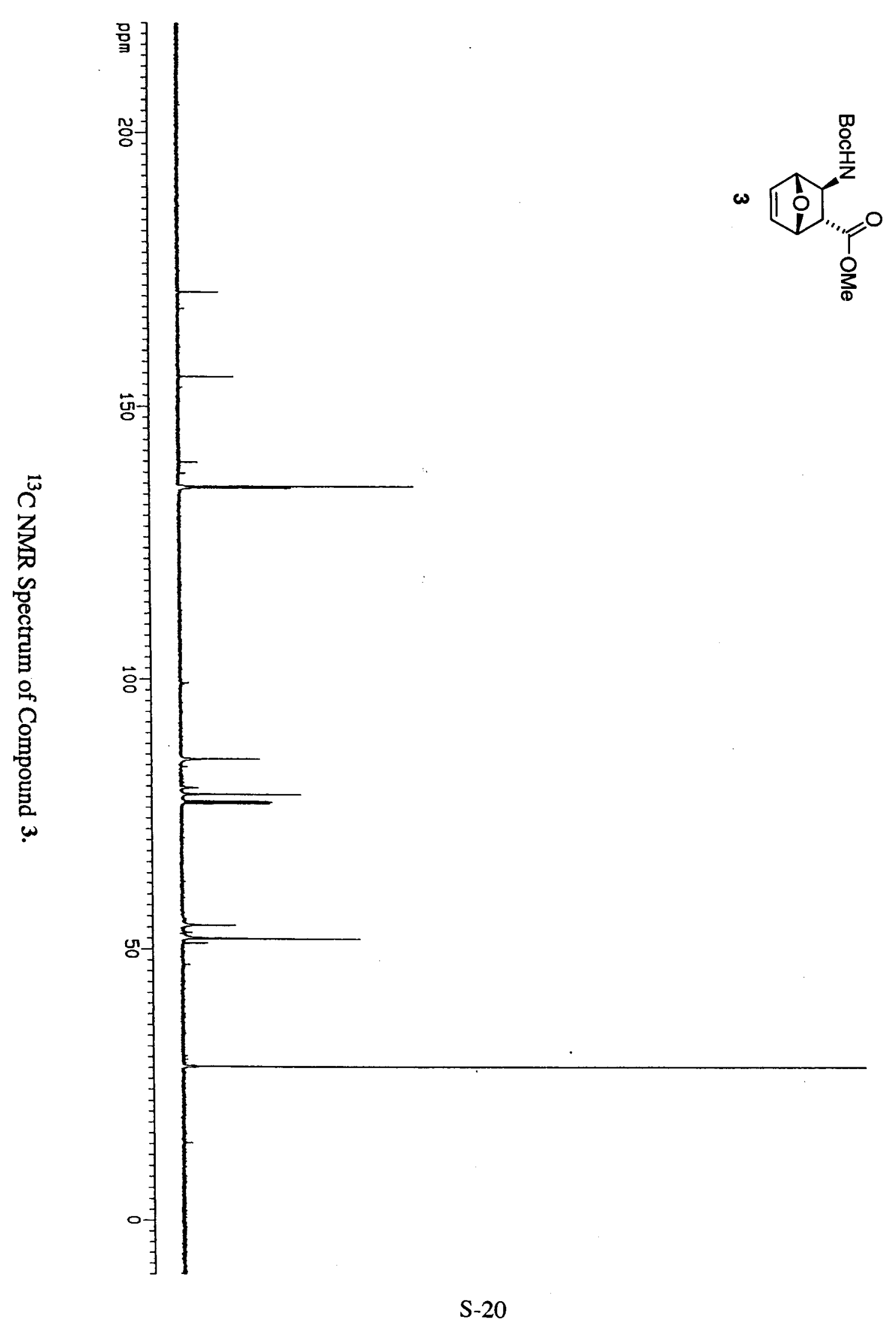




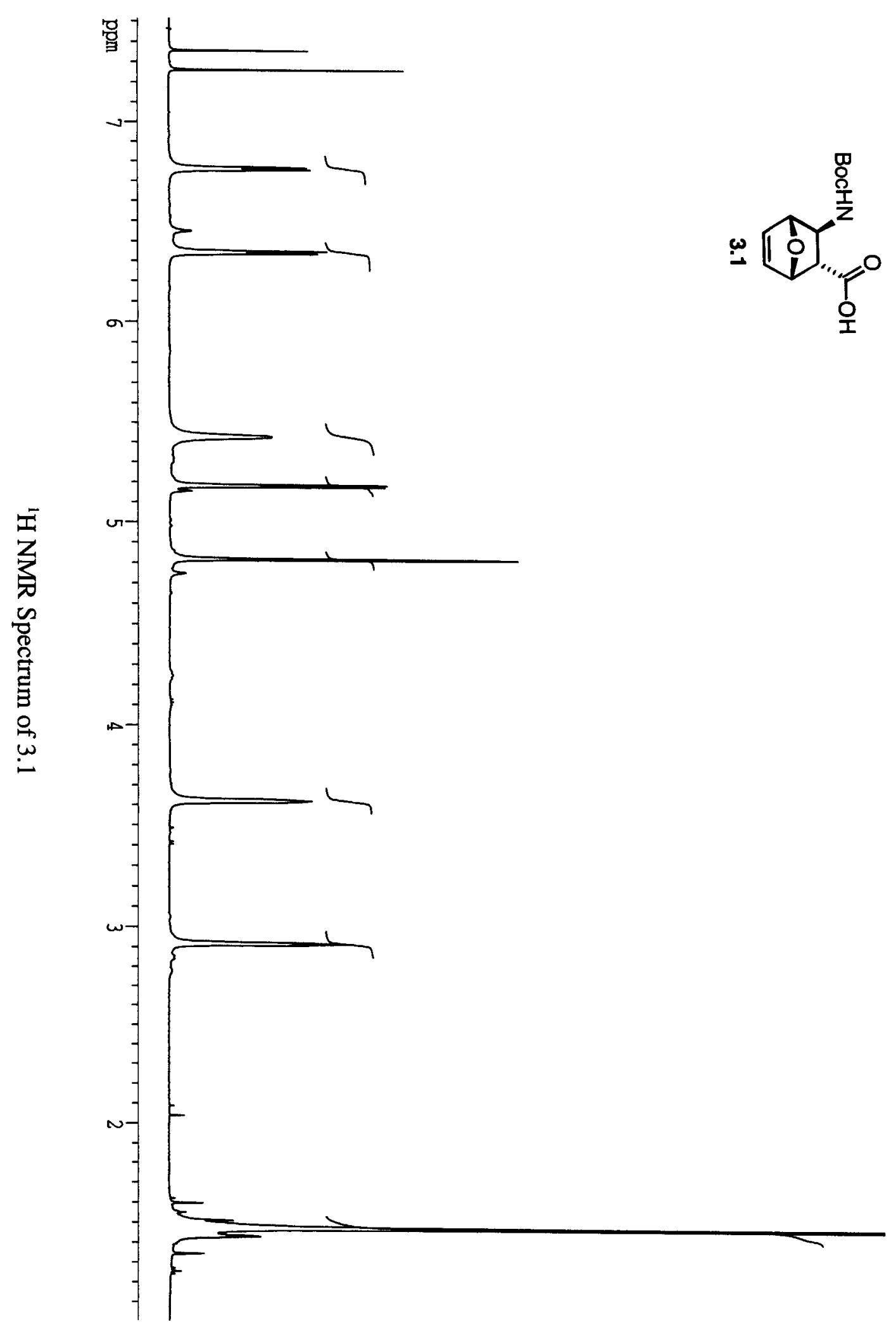




$$
\mid
$$




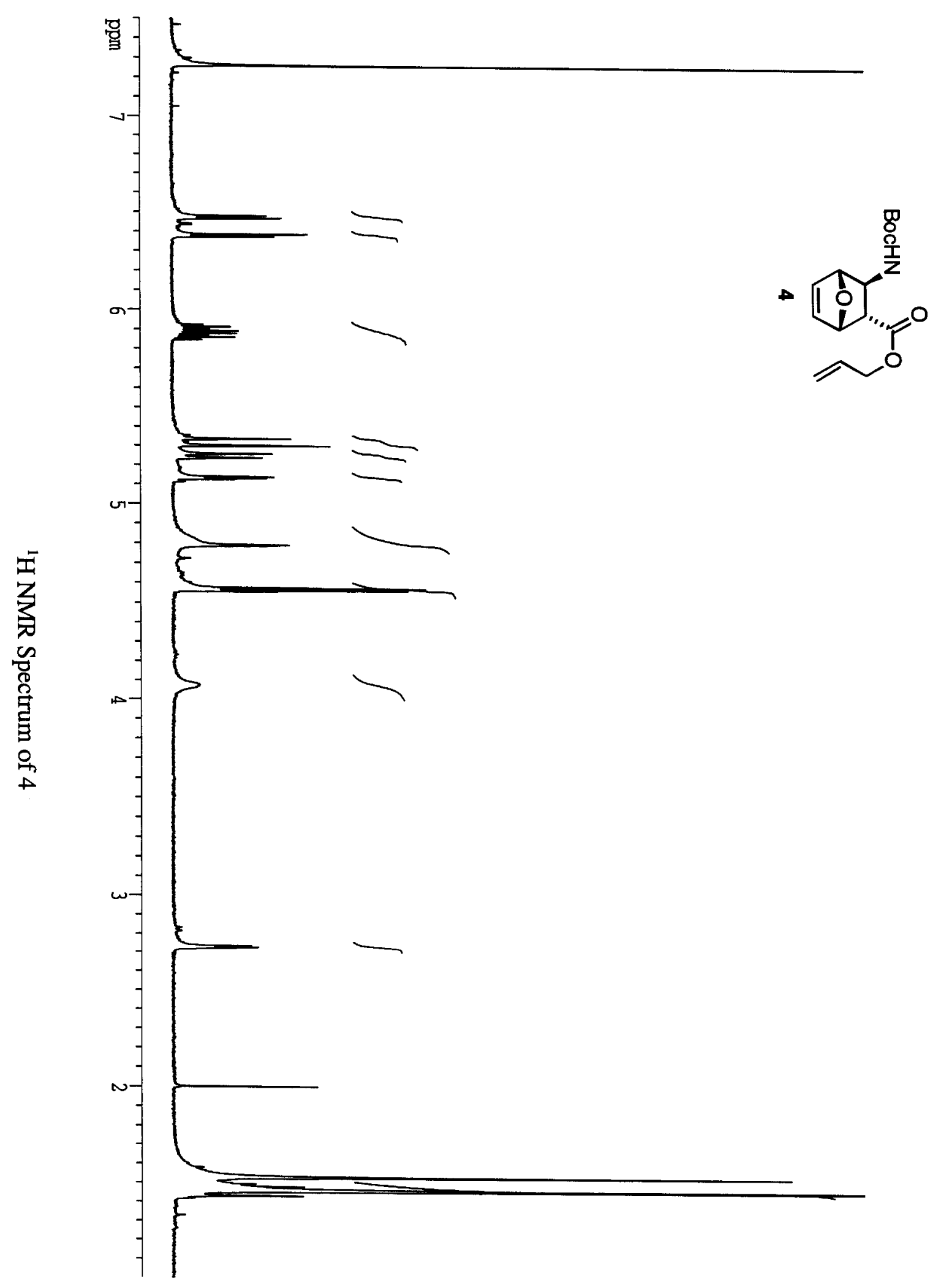




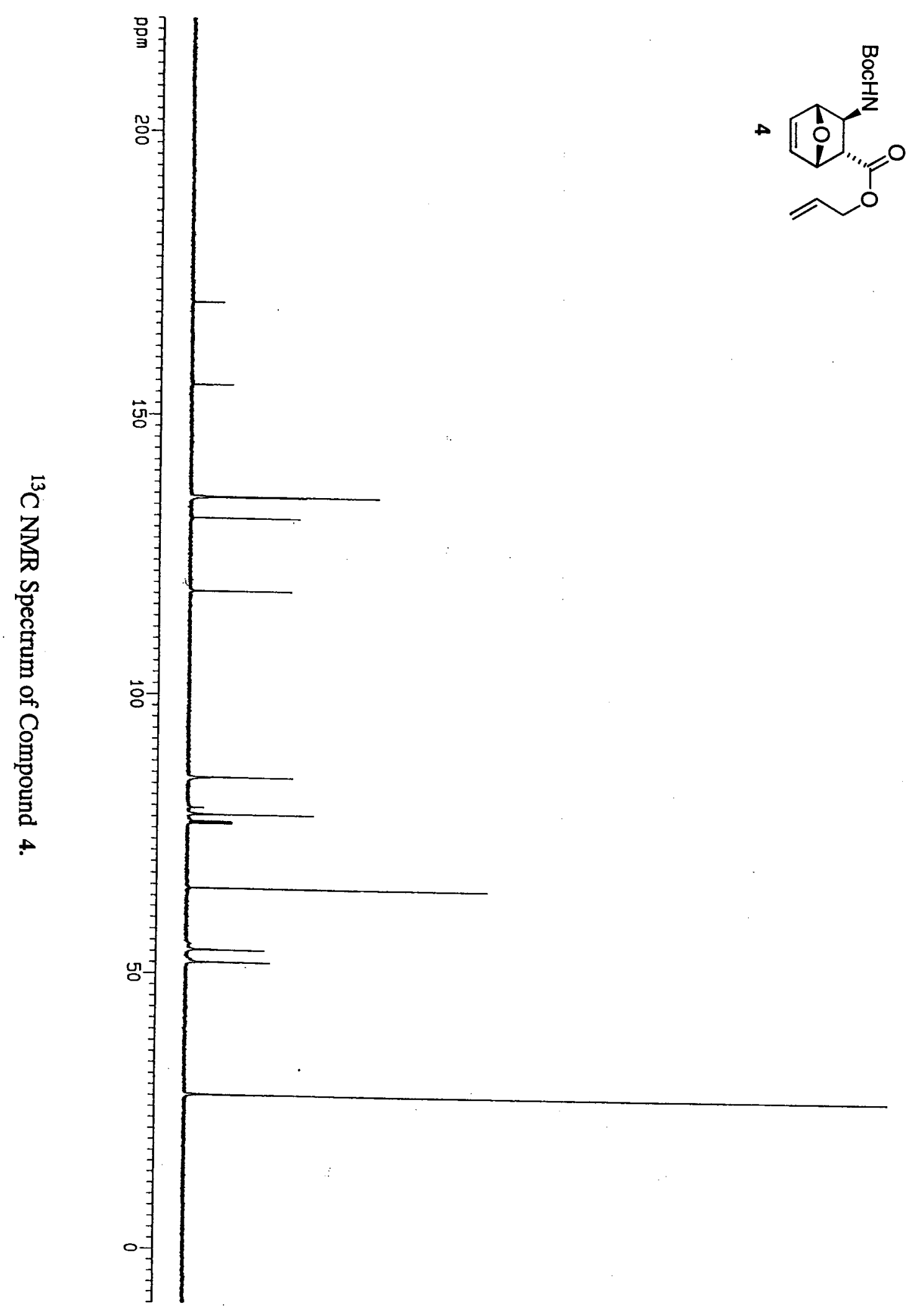

S 24 


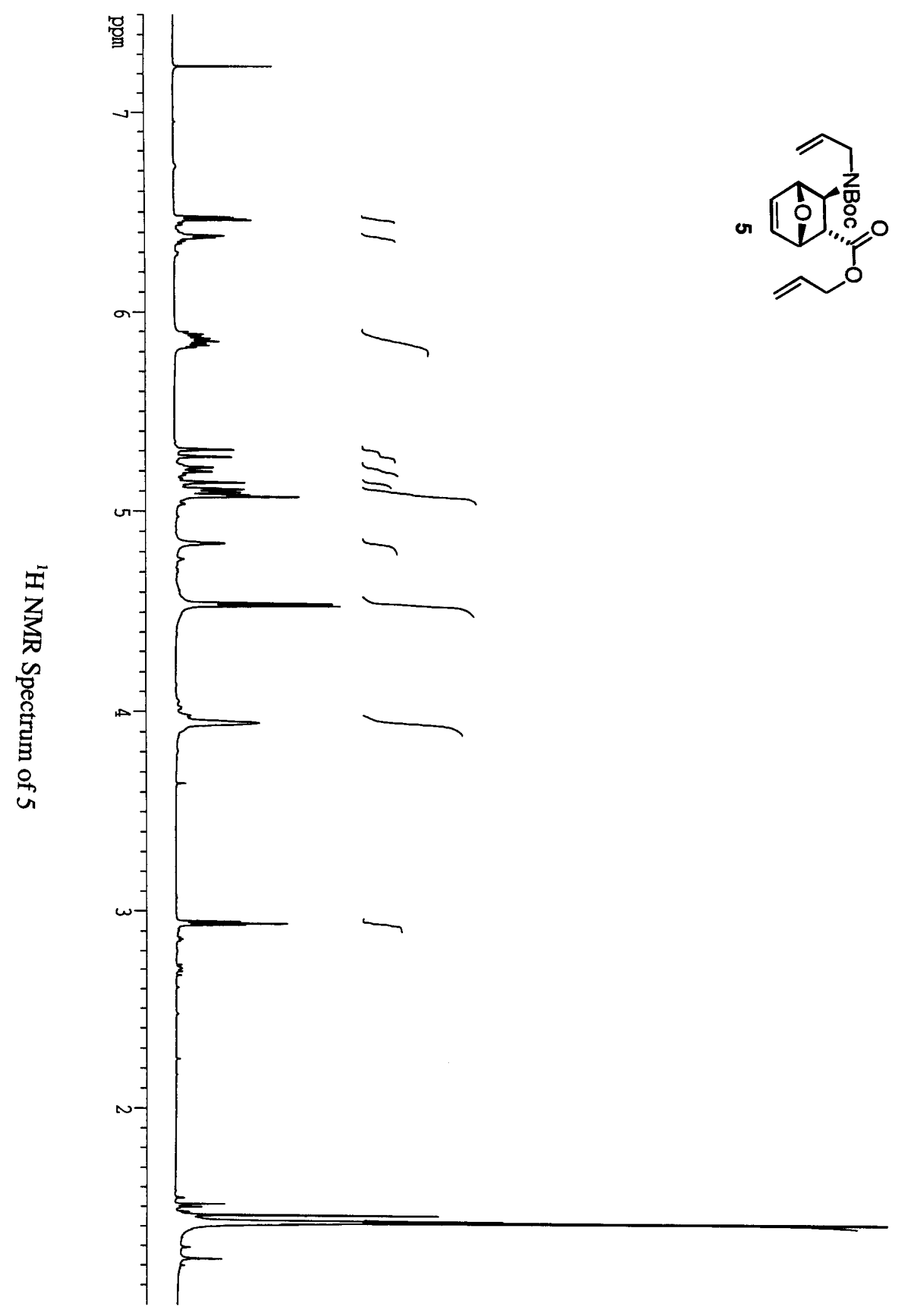




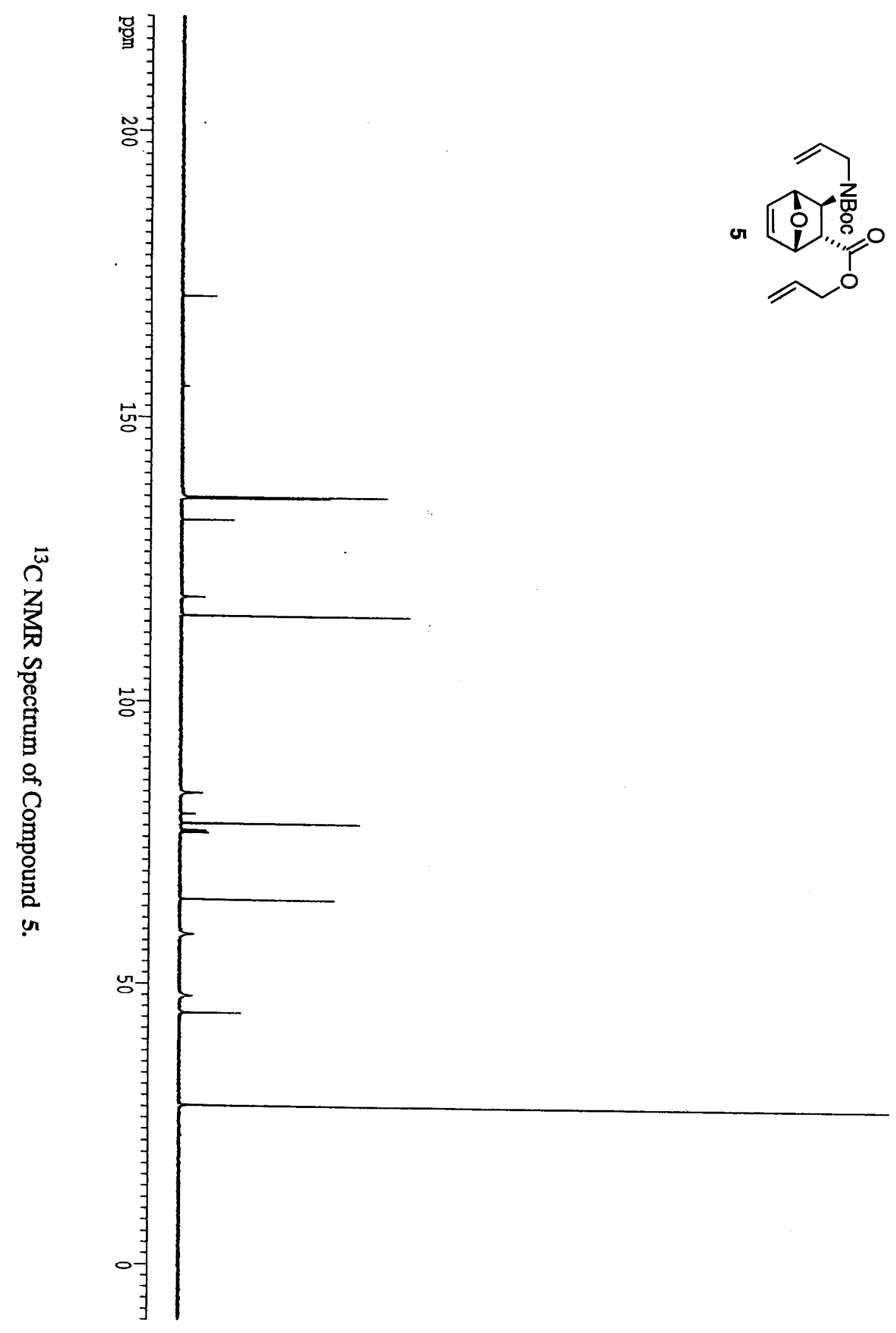




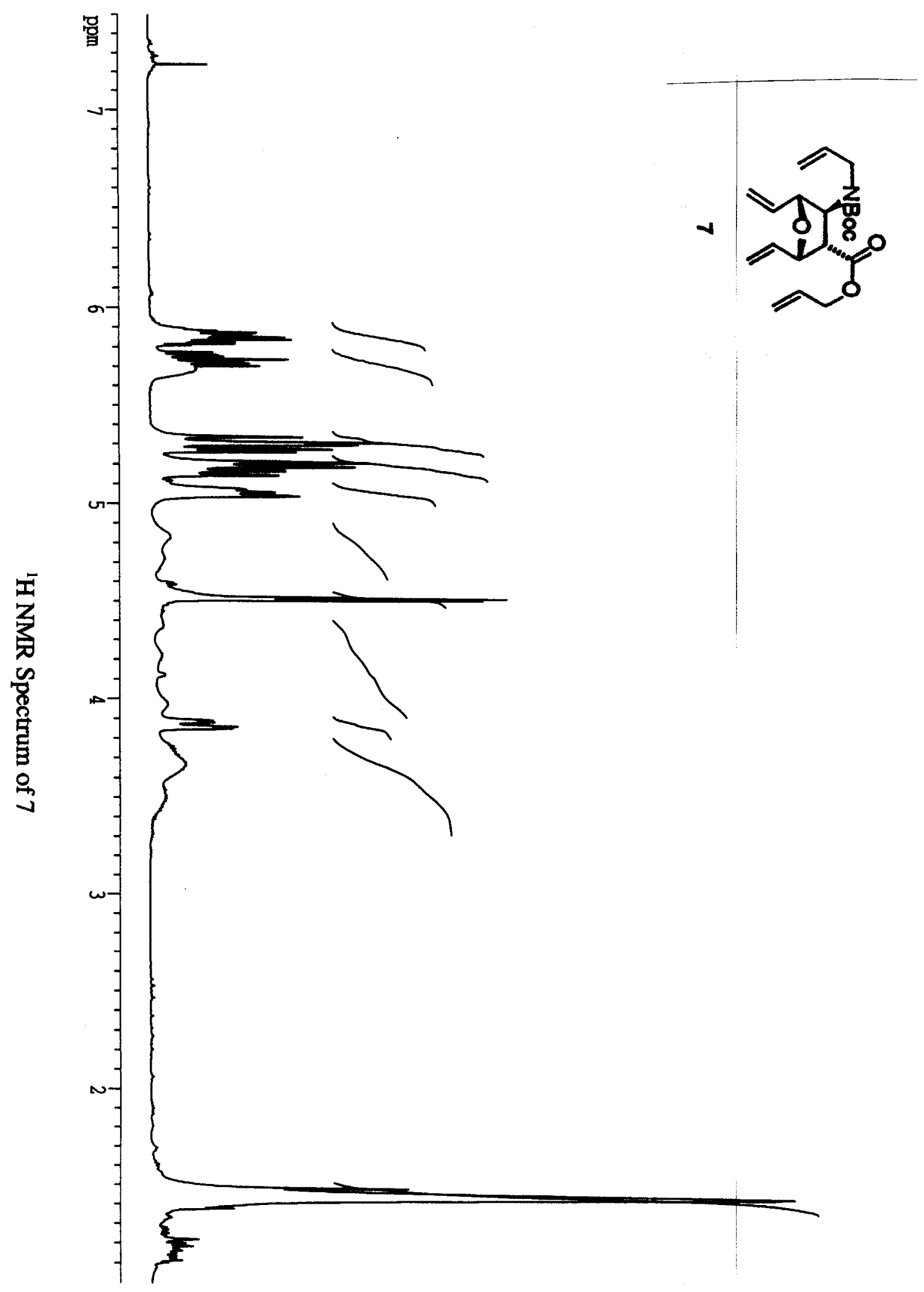




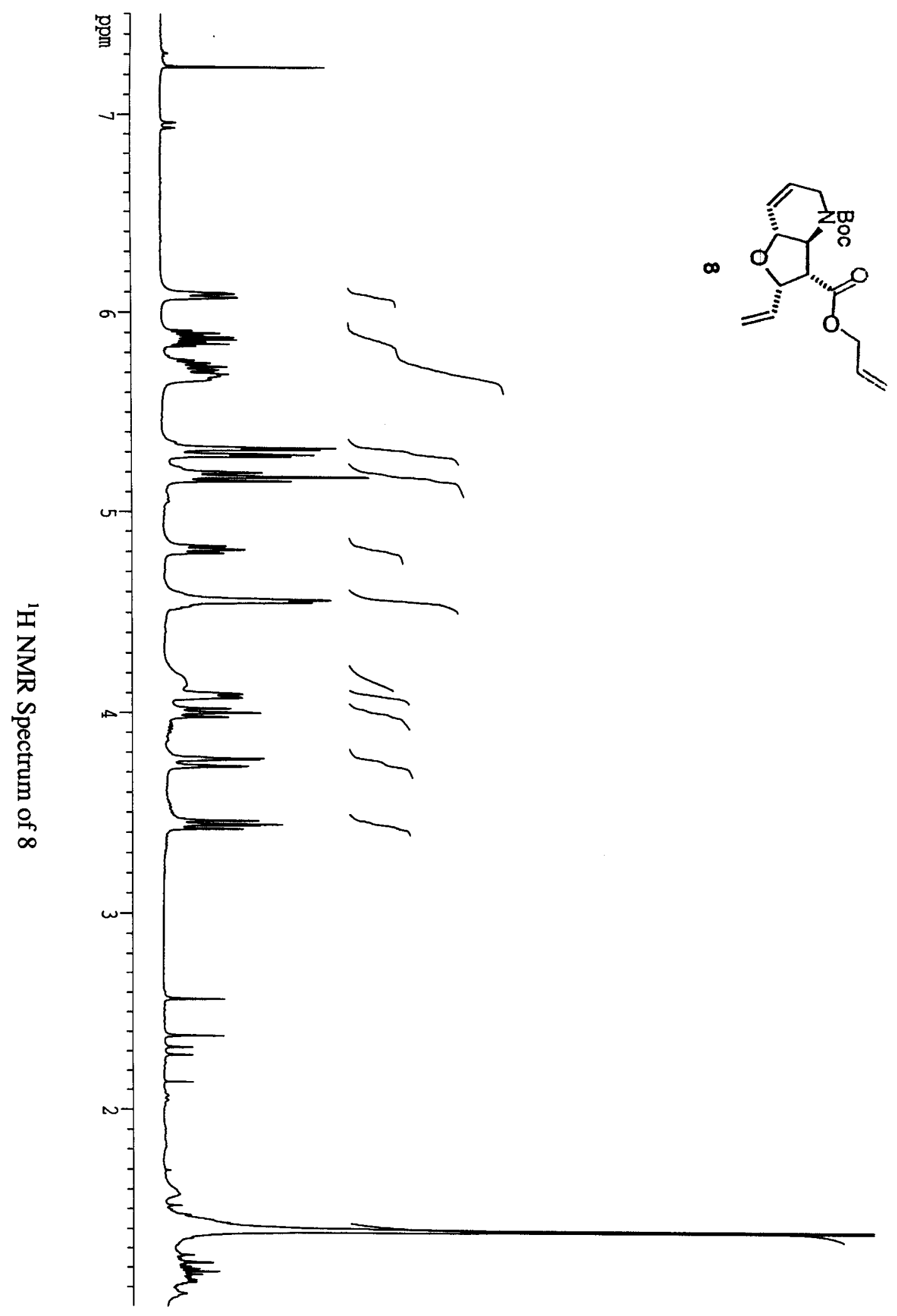




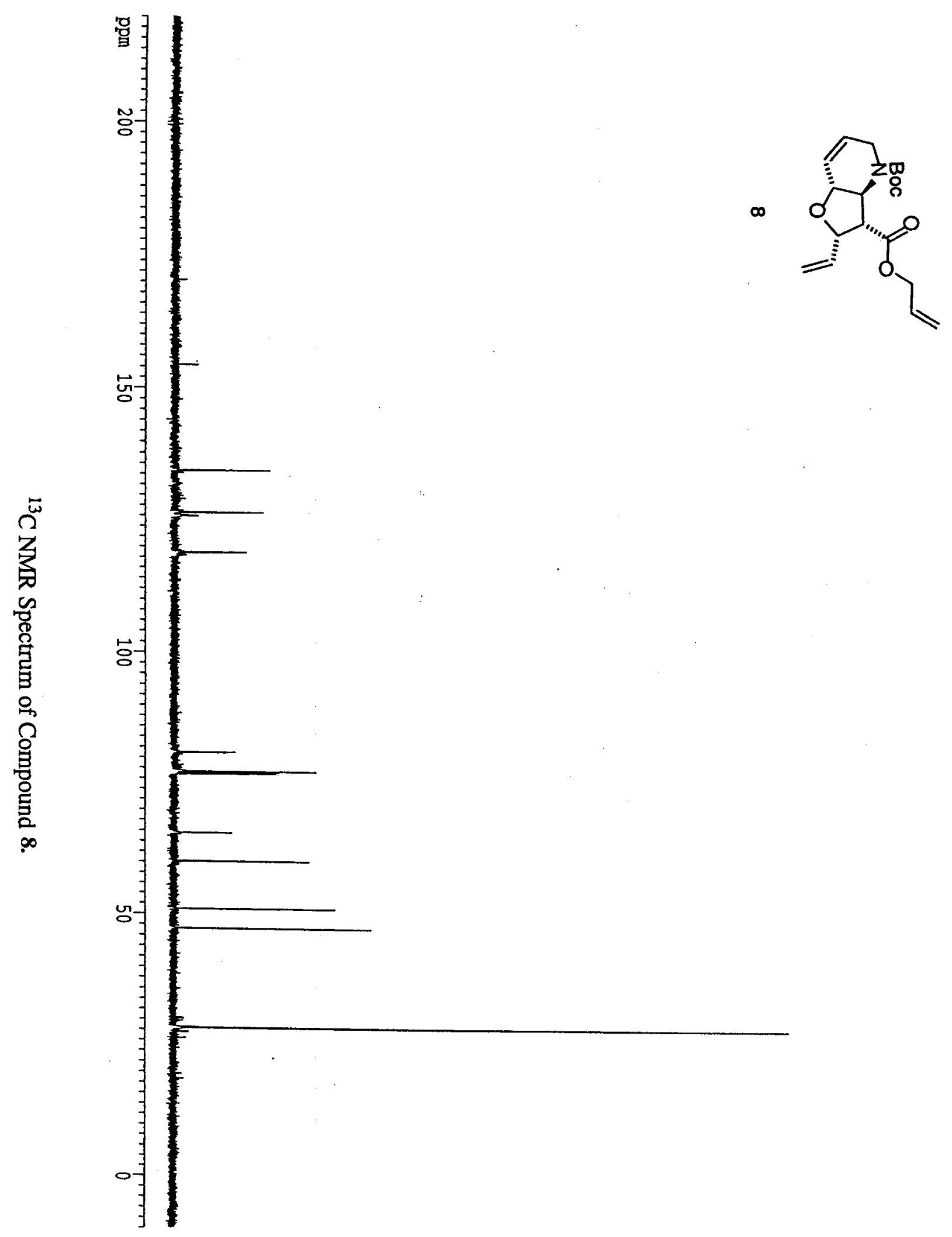




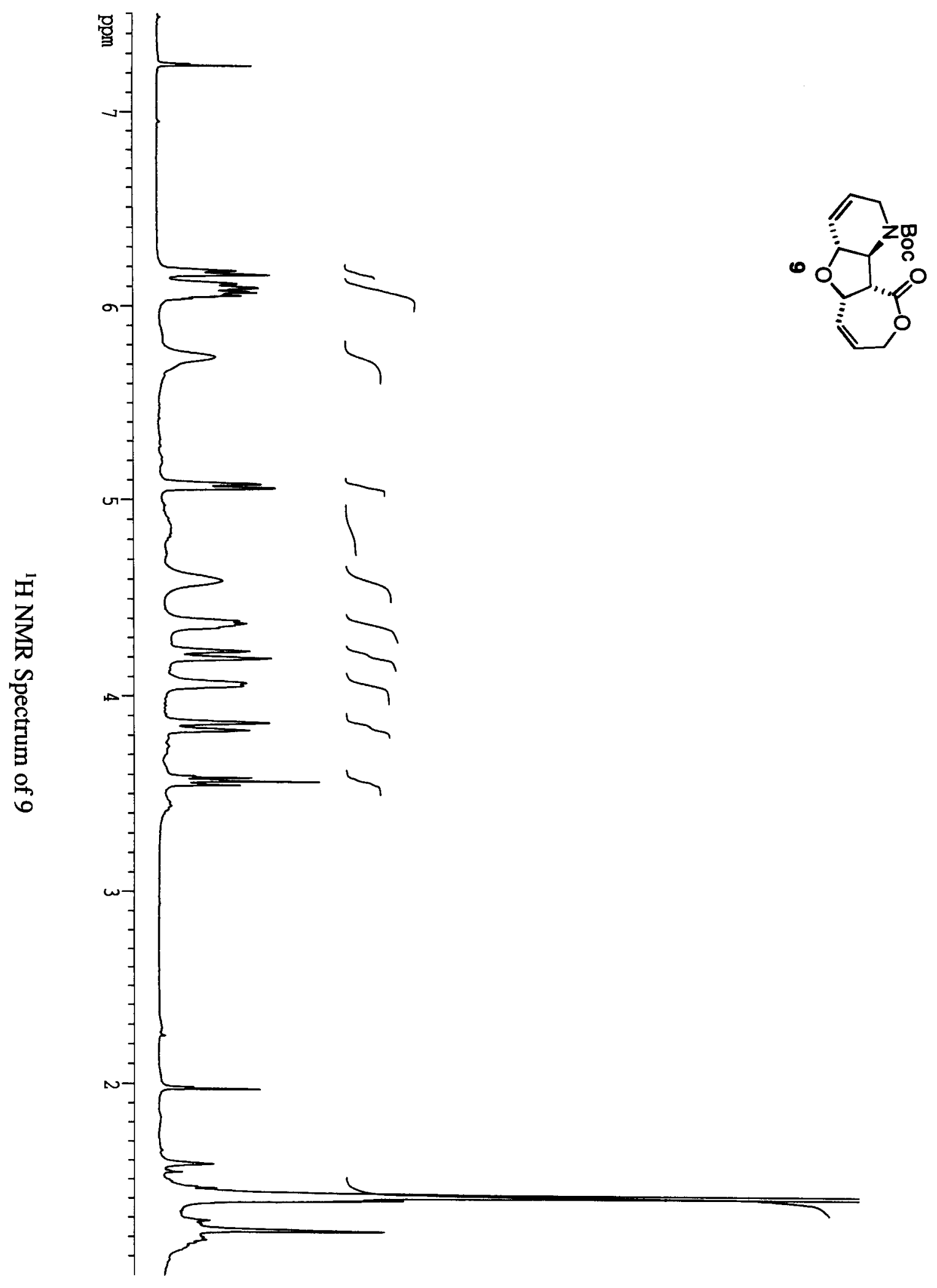




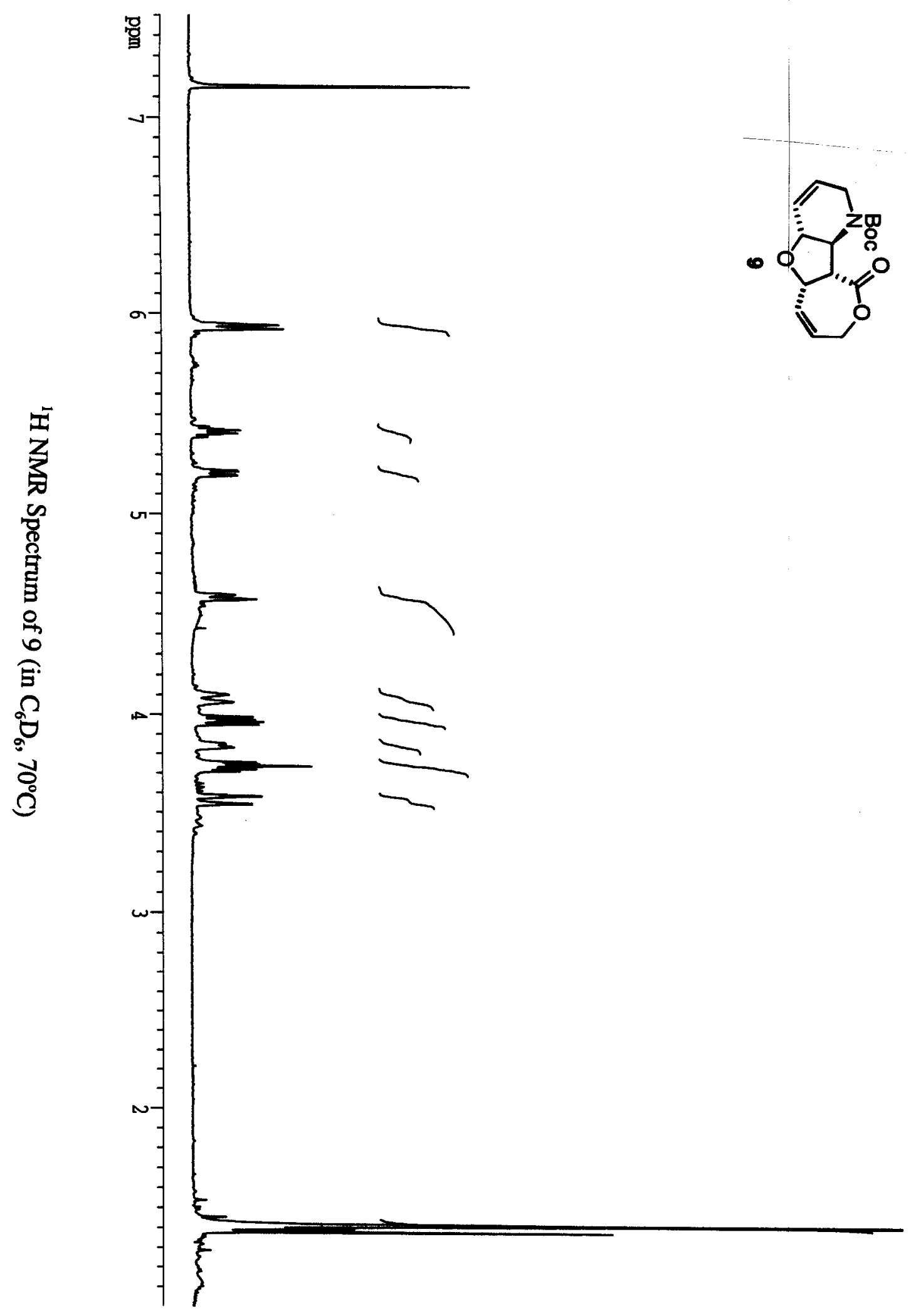




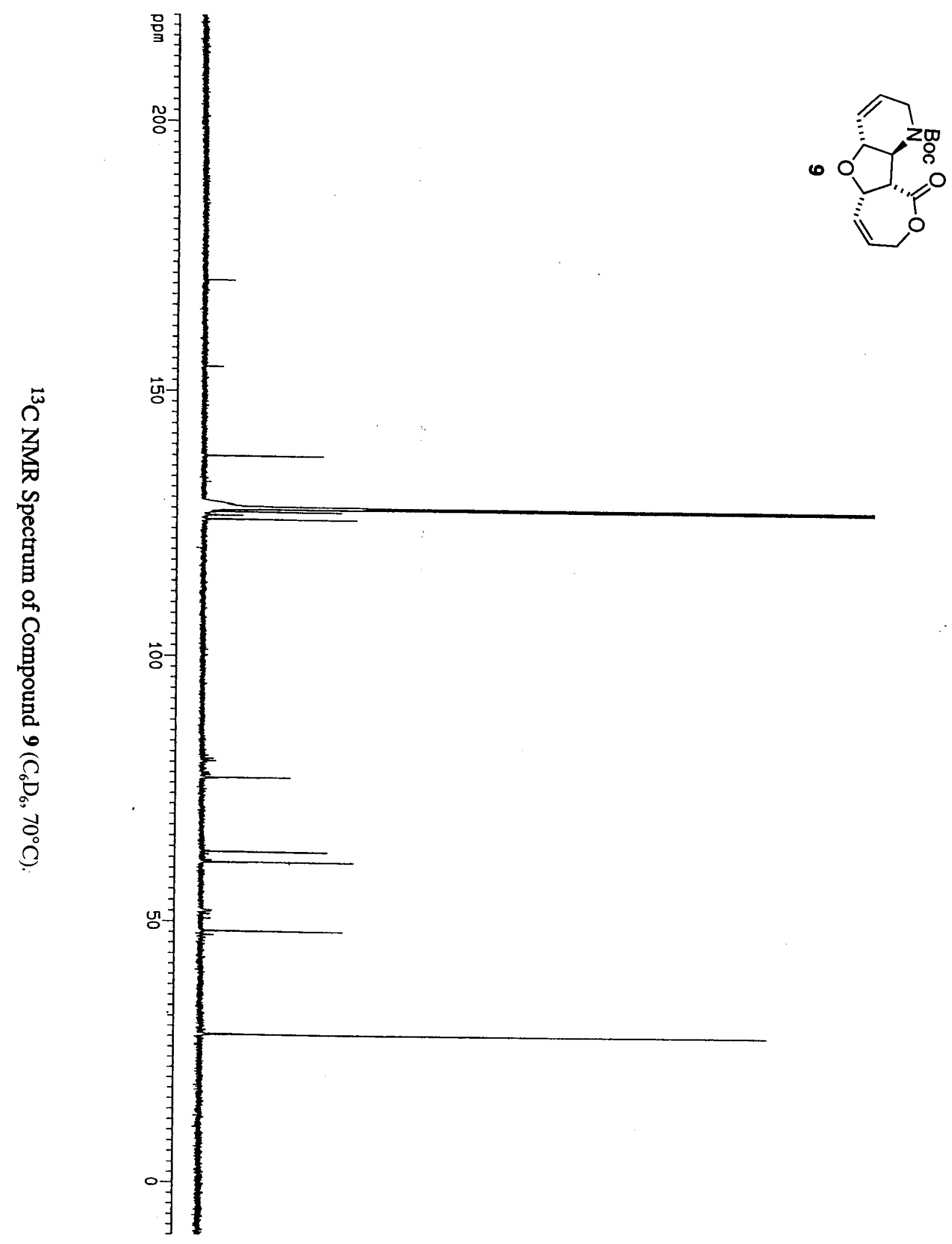

S. 32 


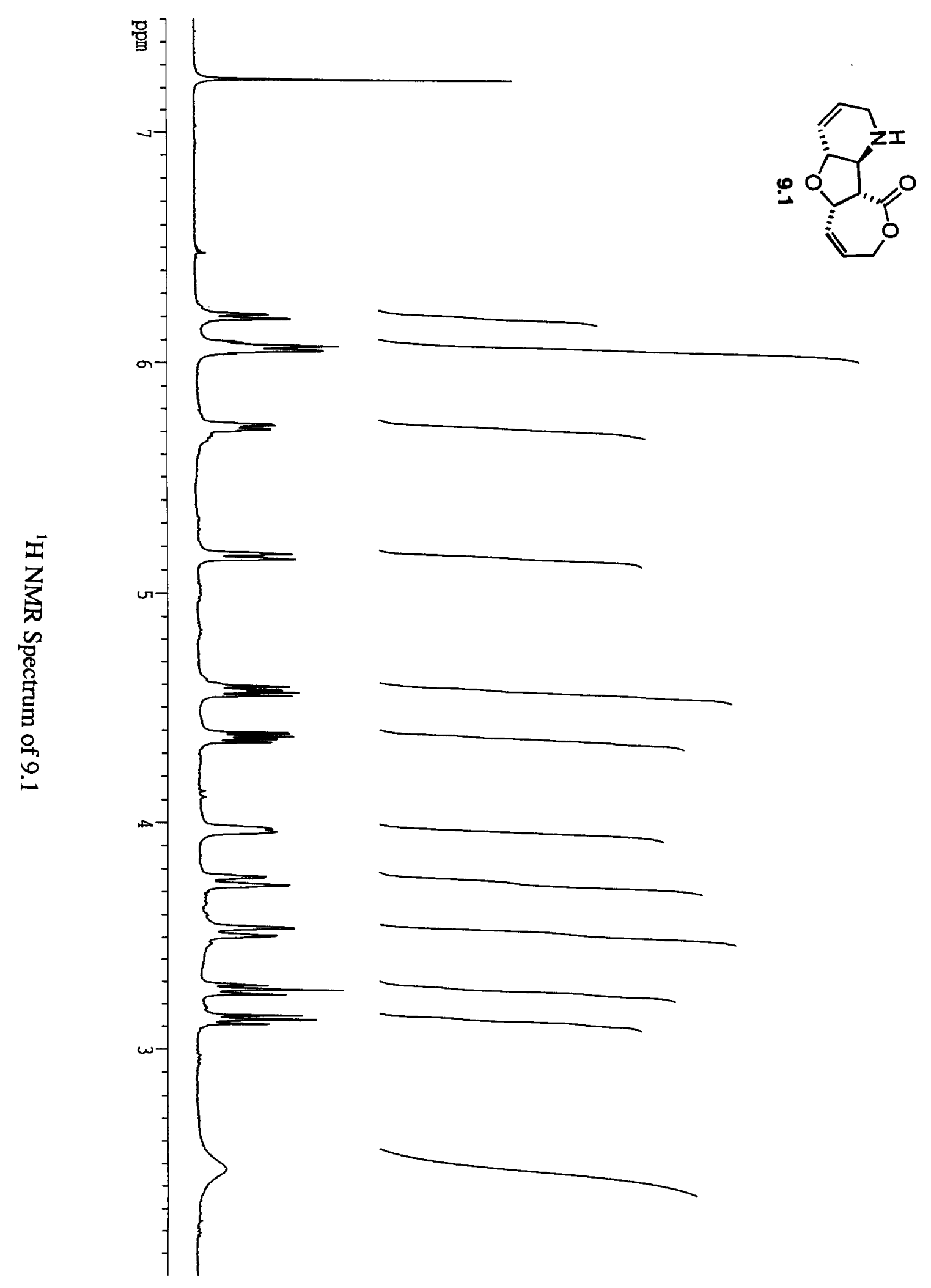




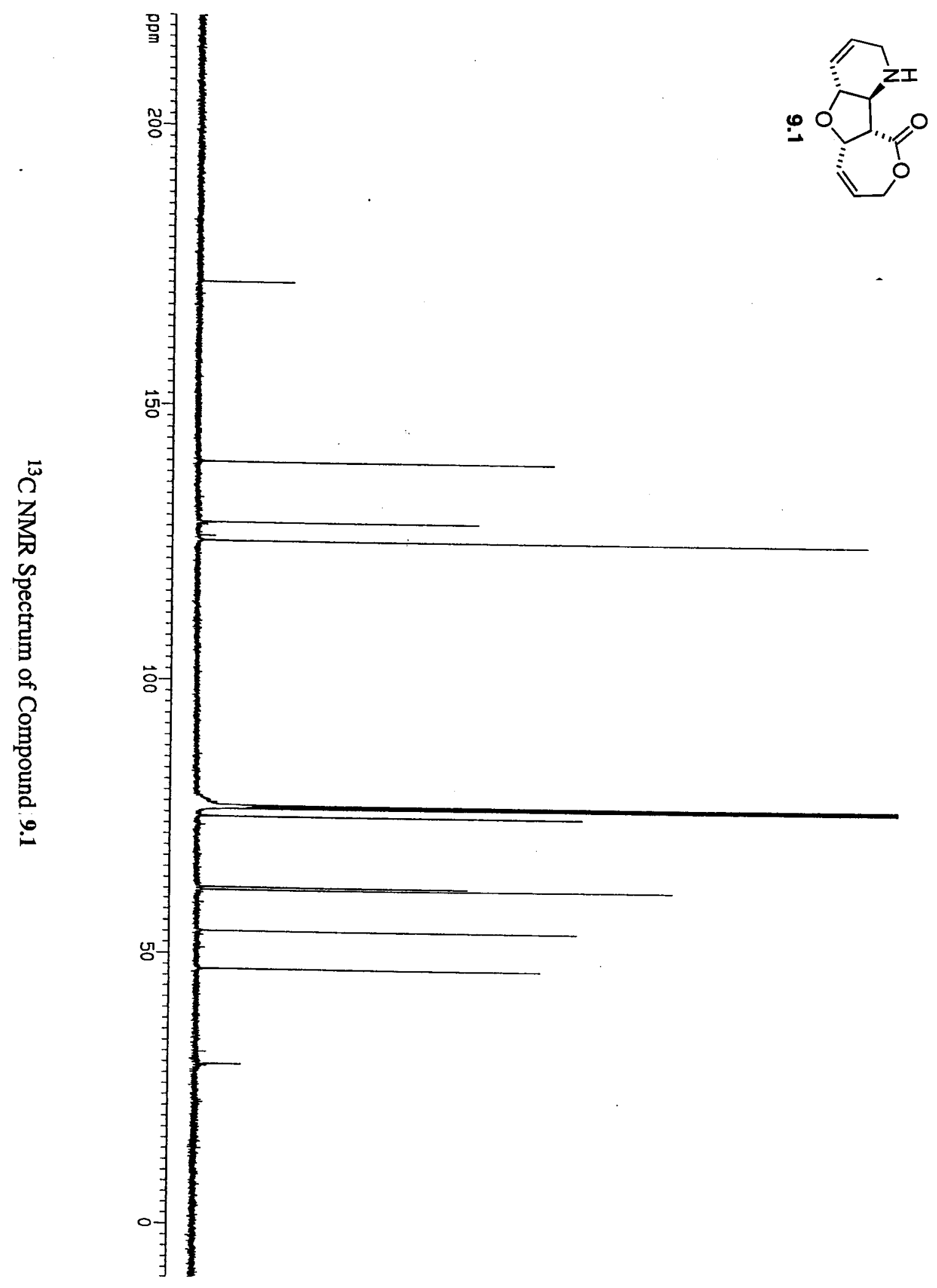

S-34 


\section{X-ray Structure Determination of Compound 9.1.}

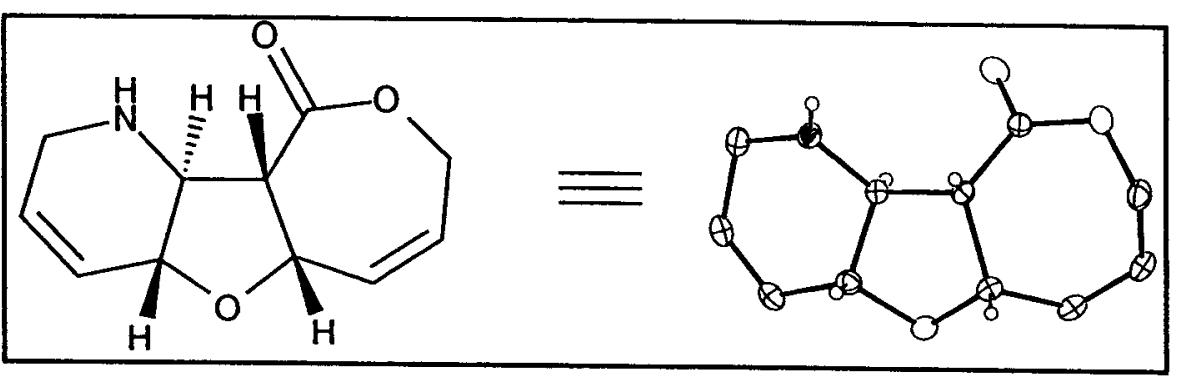

Compound 265, $\mathrm{C}_{11} \mathrm{H}_{13} \mathrm{NO}_{3}$, crystallizes in the orthorhombic space group $\mathrm{P} 2_{1} 2_{1} 2_{1}$ (systematic absences hoo: $h=0 d d, 0 k 0: k=0 d d$, and 001 : $l=0 d d$ ) with $a=5.1635(5) A$, $b=8.5138(9) \AA, c=22.427(2) \AA, V=985.9(2) \AA^{3}, Z=4$ and $d_{c a l c}=1.396 \mathrm{~g} / \mathrm{cm}^{3}$. X-ray intensity data were collected on a Rigaku Mercury CCD area detector employing graphite-monochromated Mo-K $K_{\alpha}$ radiation $(\lambda=0.71069 \AA)$ at a temperature of $143^{\circ} \mathrm{K}$. Indexing was performed from a series of four $0.5^{\circ}$ oscillation images with exposures of 30 seconds per frame. A hemisphere of data was collected using 60 second exposures and a crystal-to-detector distance of $40 \mathrm{~mm}$. A total of 440 images were collected: one sweep was performed using $\phi$-scans from $-90^{\circ}$ to $+90^{\circ}$ in $0.5^{\circ}$ steps at $\omega=0^{\circ}$ and $\chi=0^{\circ}$ with a detector swing angle of $-10^{\circ}$; a second sweep was done using $\omega$-scans from $-20^{\circ}$ to $+20^{\circ}$ in $0.5^{\circ}$ steps at $\chi=-90^{\circ}$ and $\phi=0^{\circ}$ with a detector swing angle of $-10^{\circ}$. Oscillation images were processed using CrystalClear ${ }^{1}$, producing a listing of unaveraged $F^{2}$ and $\sigma\left(F^{2}\right)$ values which were then passed to the CrystalStructure ${ }^{2}$ program package for further processing and structure solution on a Dell Pentium III computer. A total of 5213 reflections were measured over the ranges $5.12 \leq 2 \theta \leq 50.7^{\circ},-5 \leq h \leq 4,-9 \leq k \leq 7,-26$ $\leq I \leq 23$ yielding 1687 unique reflections $\left(R_{\text {int }}=0.0158\right)$. The intensity data were corrected for Lorentz and polarization effects and for absorption. using REQAB ${ }^{3}$ (minimum and maximum transmission $0.848,1.000)$.

The structure was solved by direct methods (SIR974). Refinement was by full-matrix least squares based on $\mathrm{F}^{2}$ using SHELXL-975. All reflections were used during refinement 
$\left(F^{2}\right.$ 's that were experimentally negative were replaced by $\left.F^{2}=0\right)$. The weighting scheme used was $w=1 /\left[\sigma^{2}\left(F_{0}^{2}\right)+0.0591 P^{2}+0.3089 P\right]$ where $P=\left(F_{0}^{2}+2 F_{c}^{2}\right) / 3$. Non-hydrogen atoms were refined anisotropically and hydrogen atoms were refined using a "riding" model. Refinement converged to $R_{1}=0.0364$ and $w R_{2}=0.0981$ for 1645 reflections for which $F>4 \sigma(F)$ and $R_{1}=0.0373, w R_{2}=0.0992$ and GOF $=1.073$ for all 1687 unique, non-zero reflections and 136 variables $^{6}$. The maximum $\Delta \sigma \sigma$ in the final cycle of least squares was 0.000 and the two most prominent peaks in the final difference Fourier were +0.457 and $-0.460 \mathrm{e} / \AA^{3}$.

Table 1. lists cell information, data collection parameters, and refinement data. Final positional and equivalent isotropic thermal parameters are given in Table 2. Anisotropic thermal parameters are in Table 3. Tables 4. and 5. list bond distances and bond angles. Figure 1. is an ORTEP ${ }^{7}$ representation of the molecule with $30 \%$ probability thermal ellipsoids displayed.

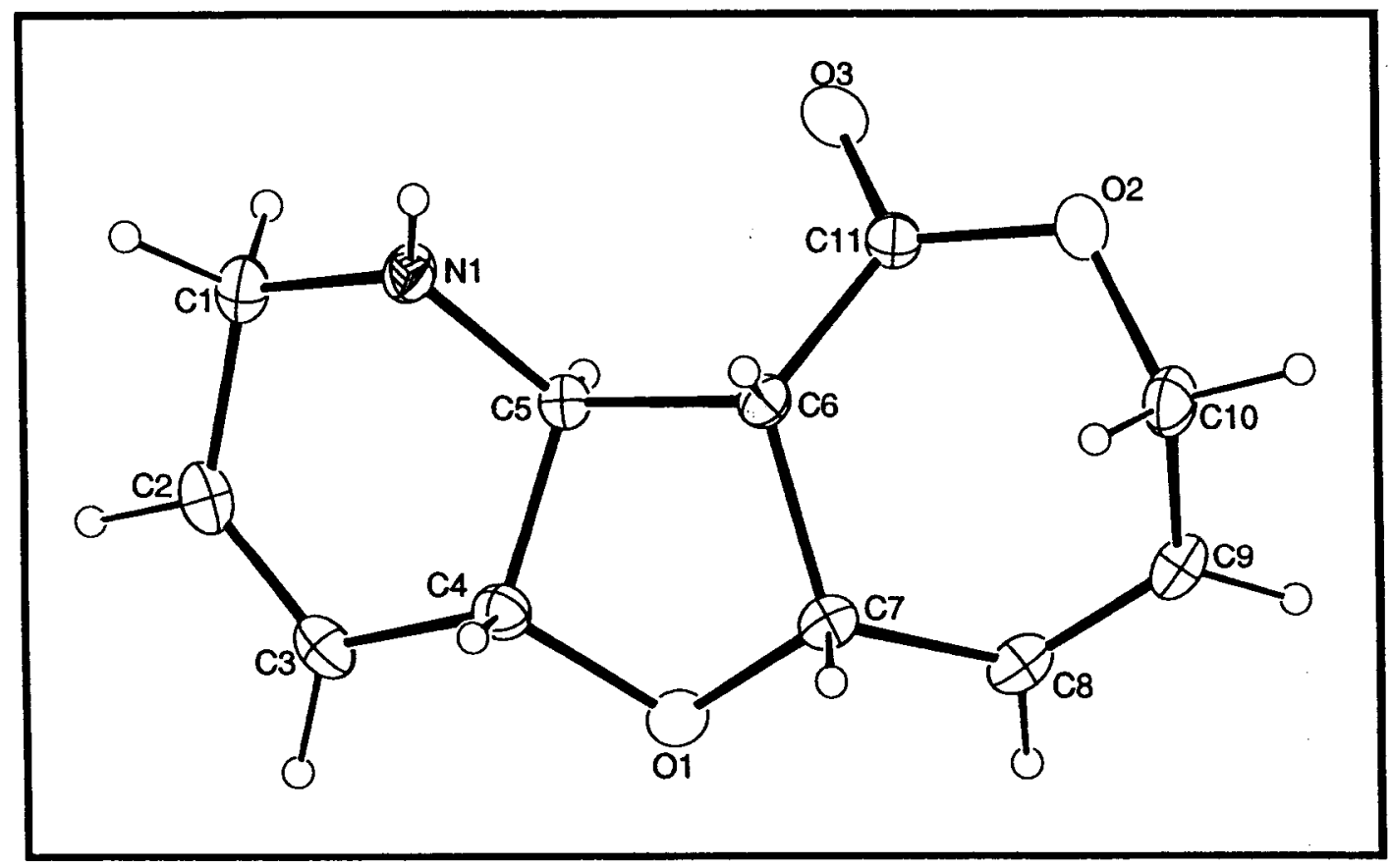

Figure 1. ORTEP drawing of the title compound with $30 \%$ probability thermal ellipsoids. 


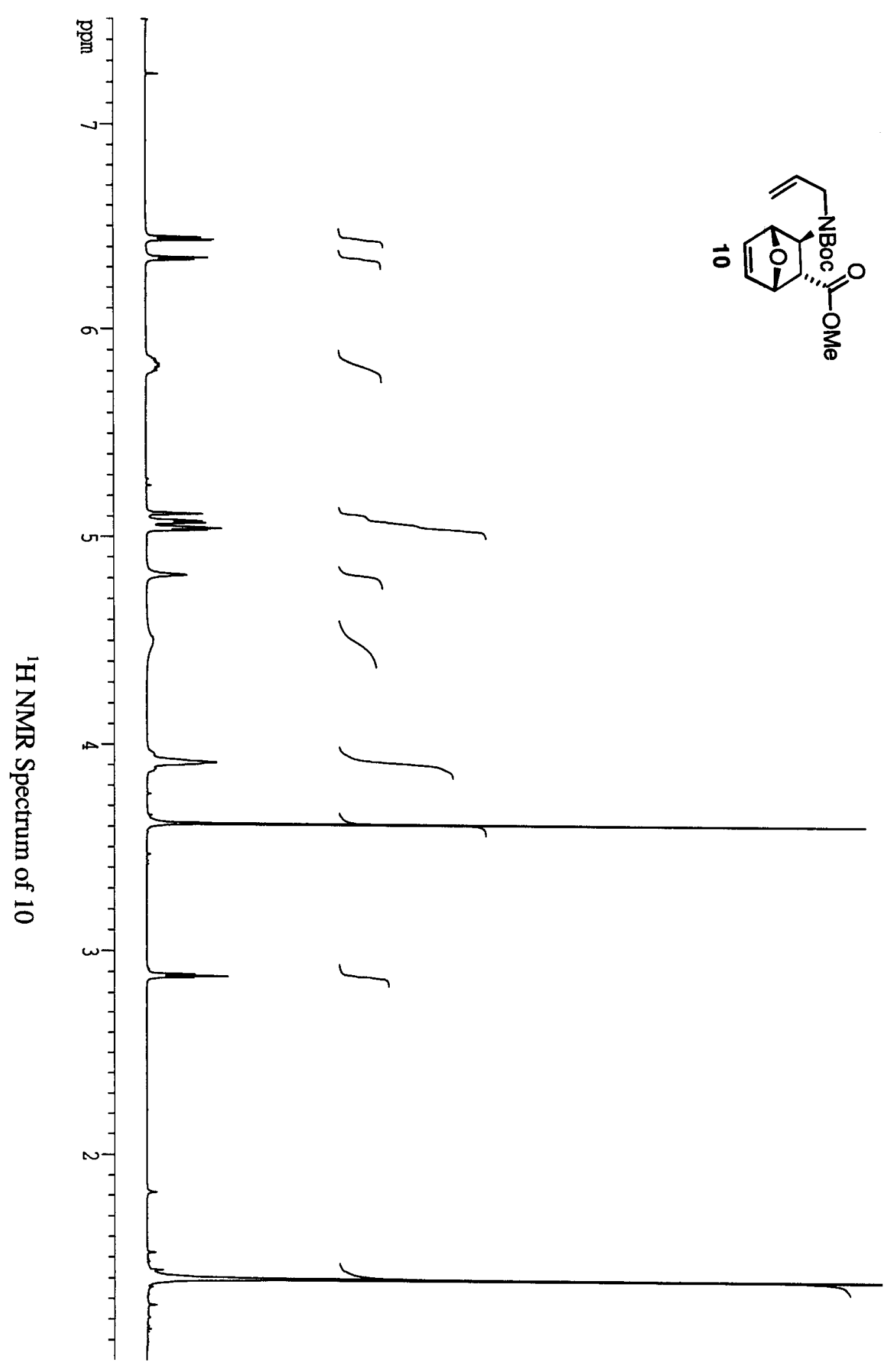

S37 


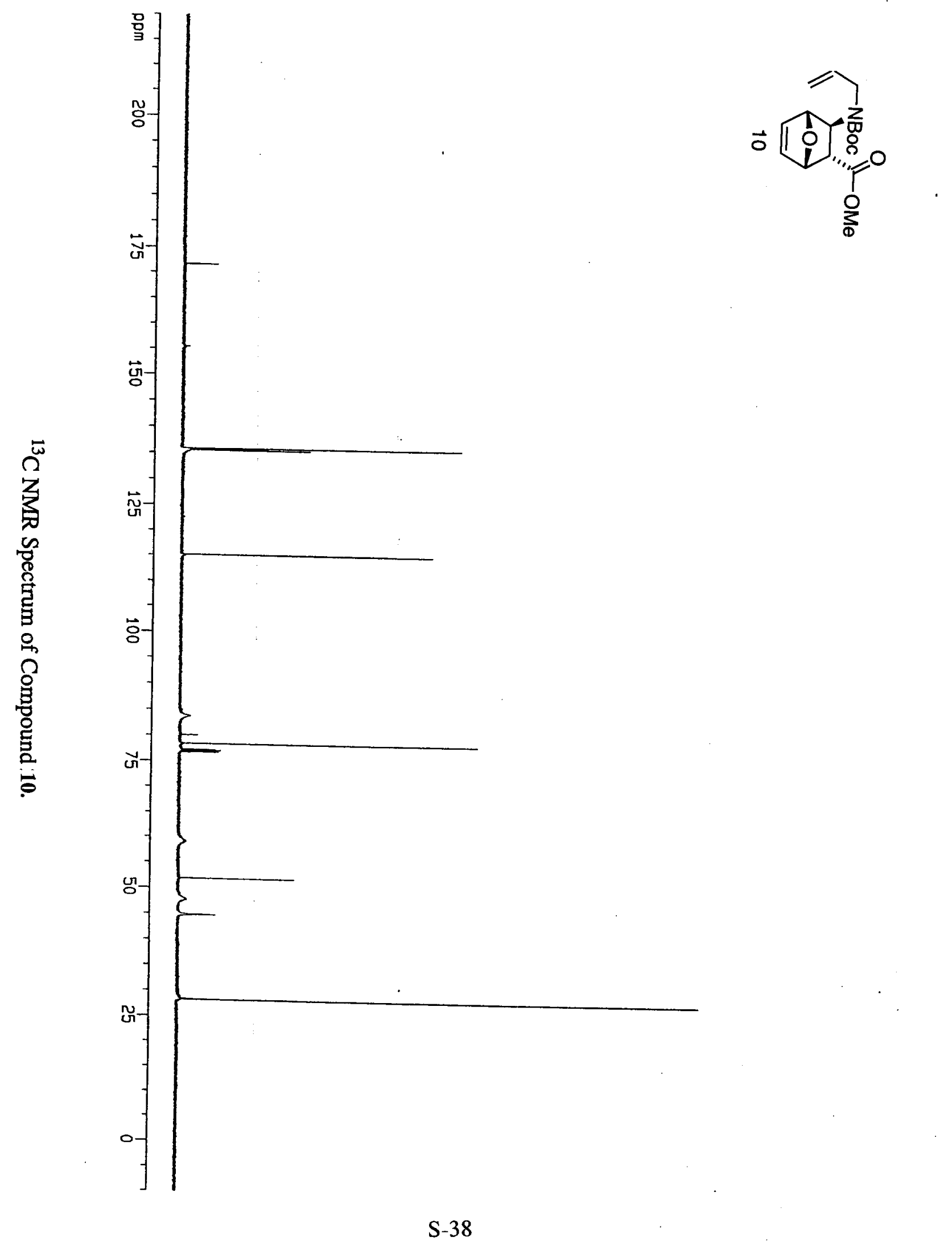




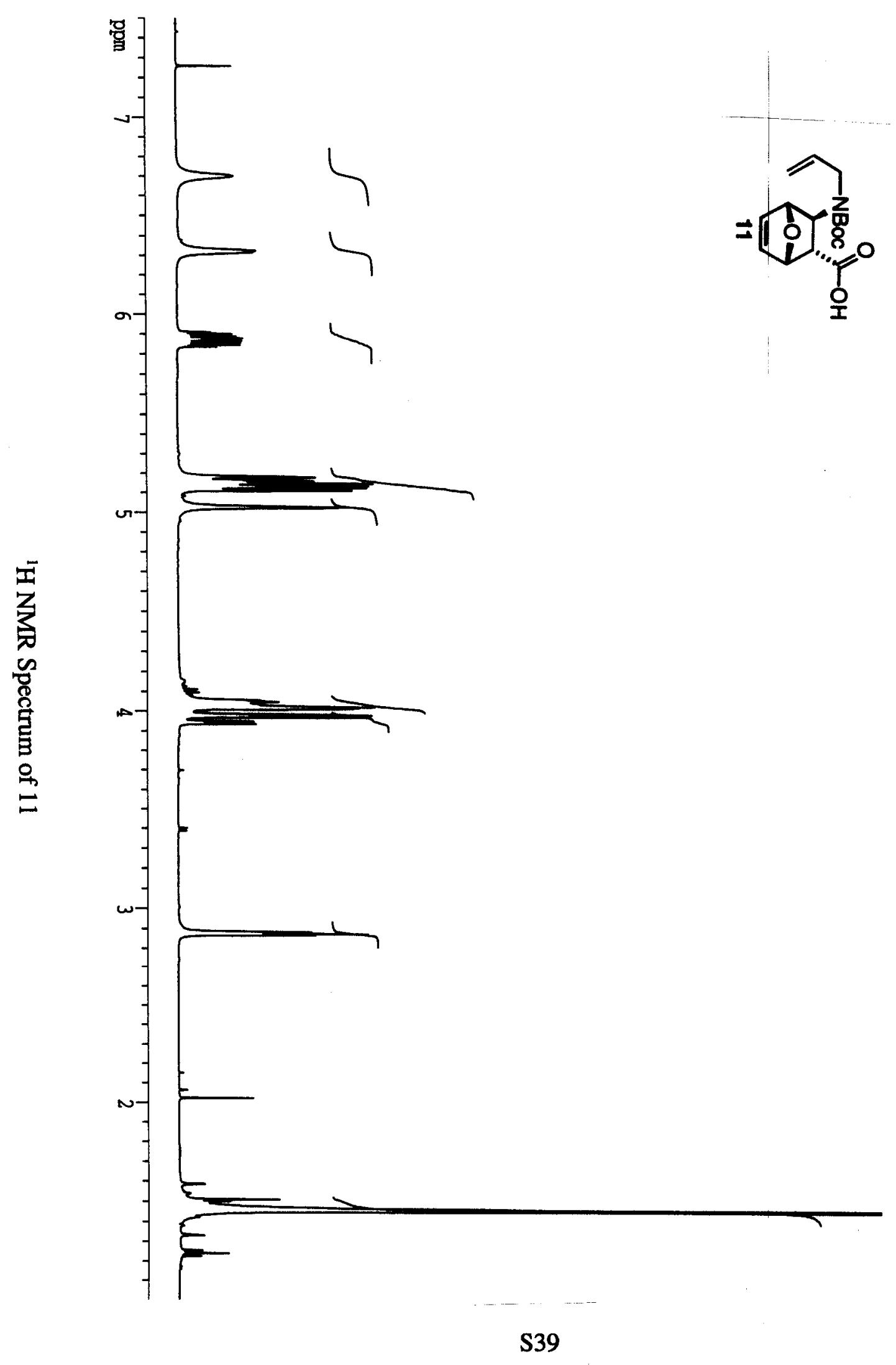




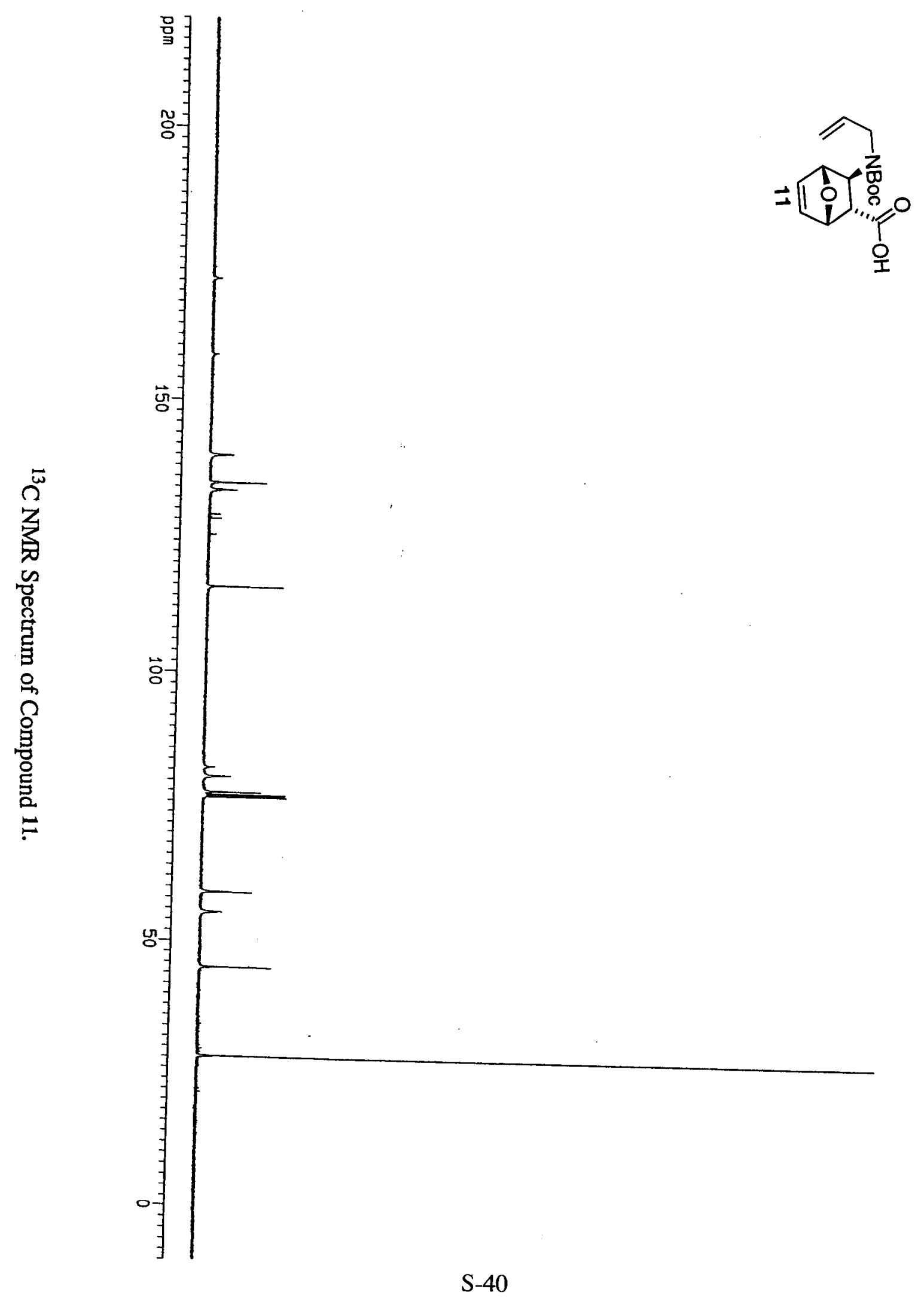




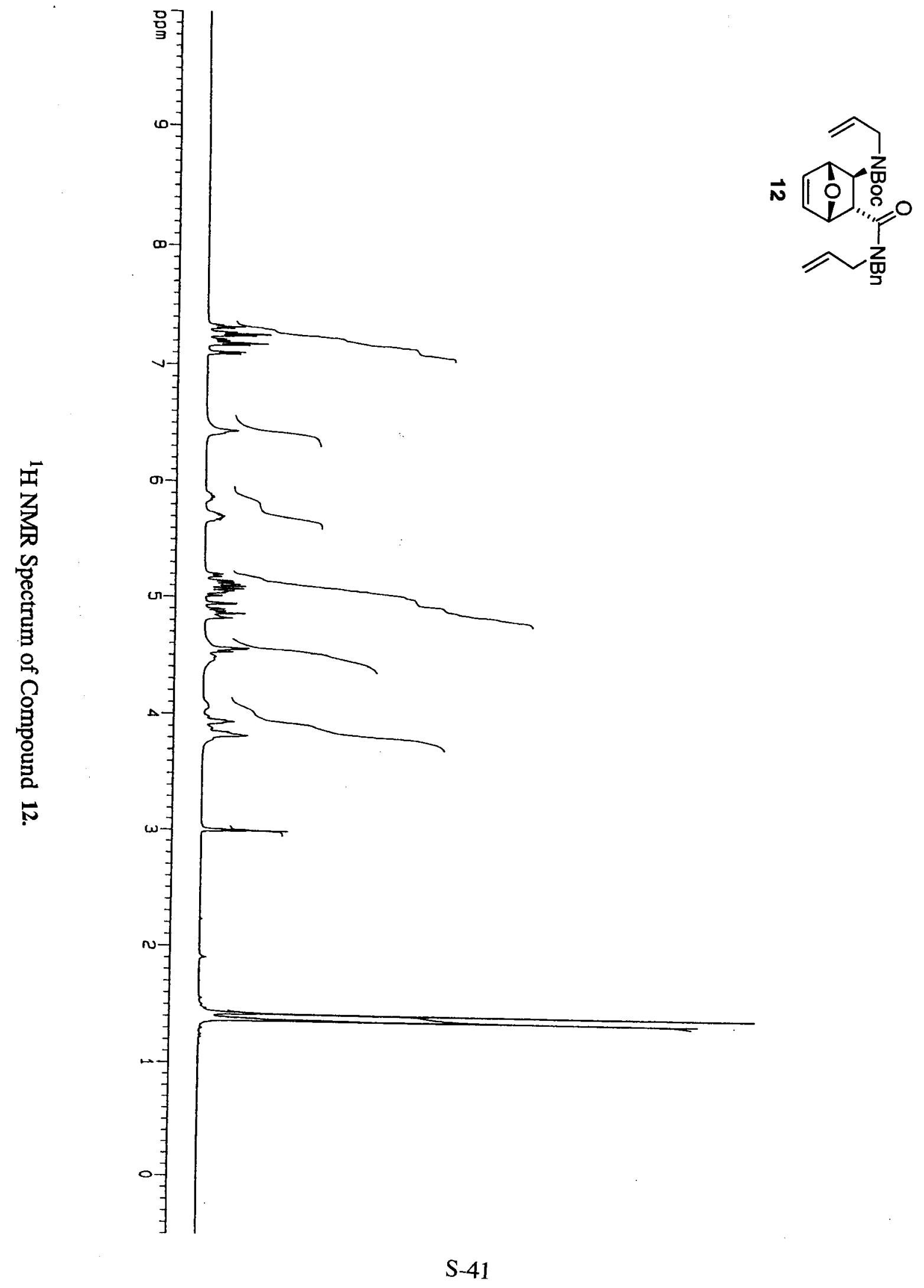




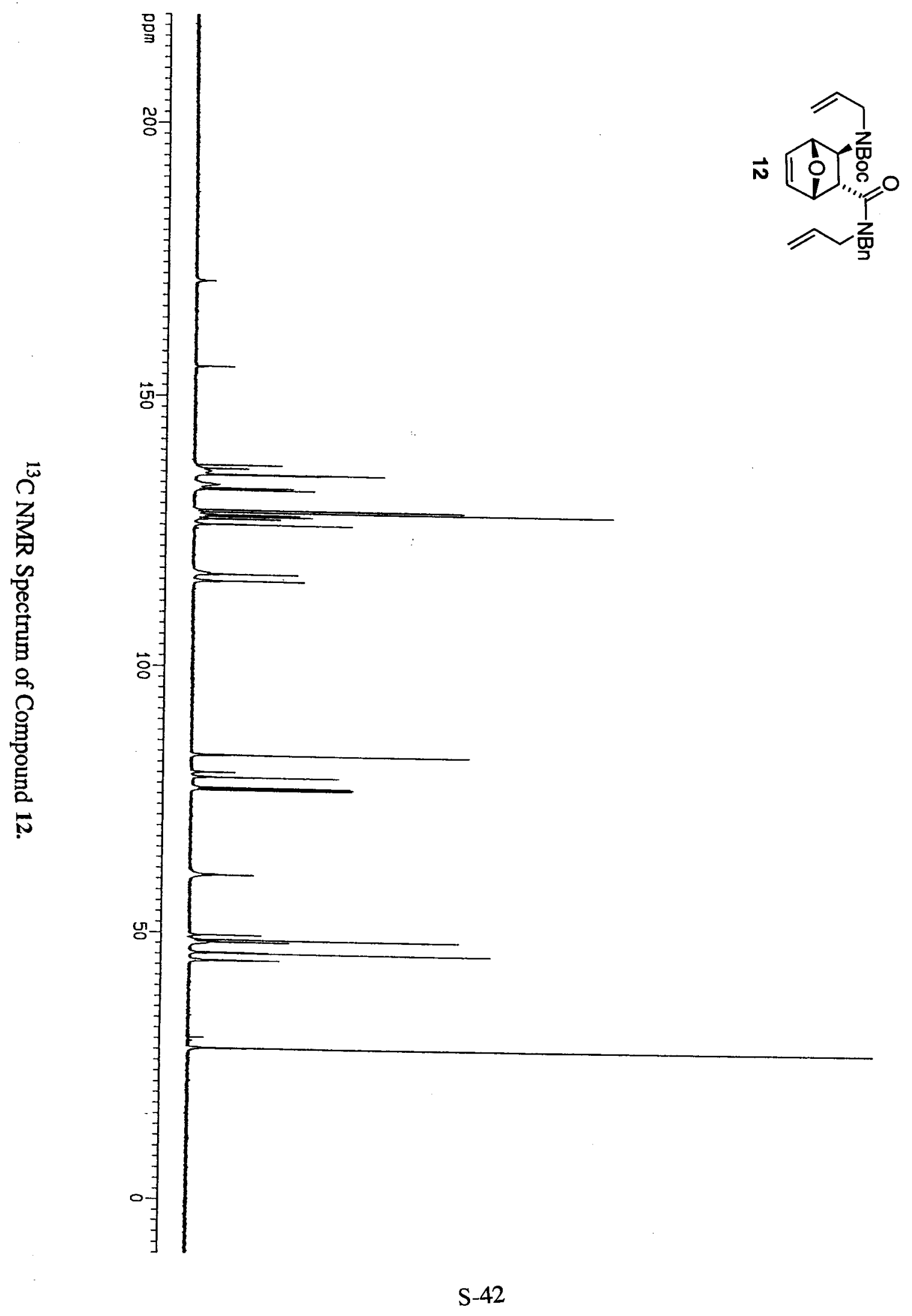




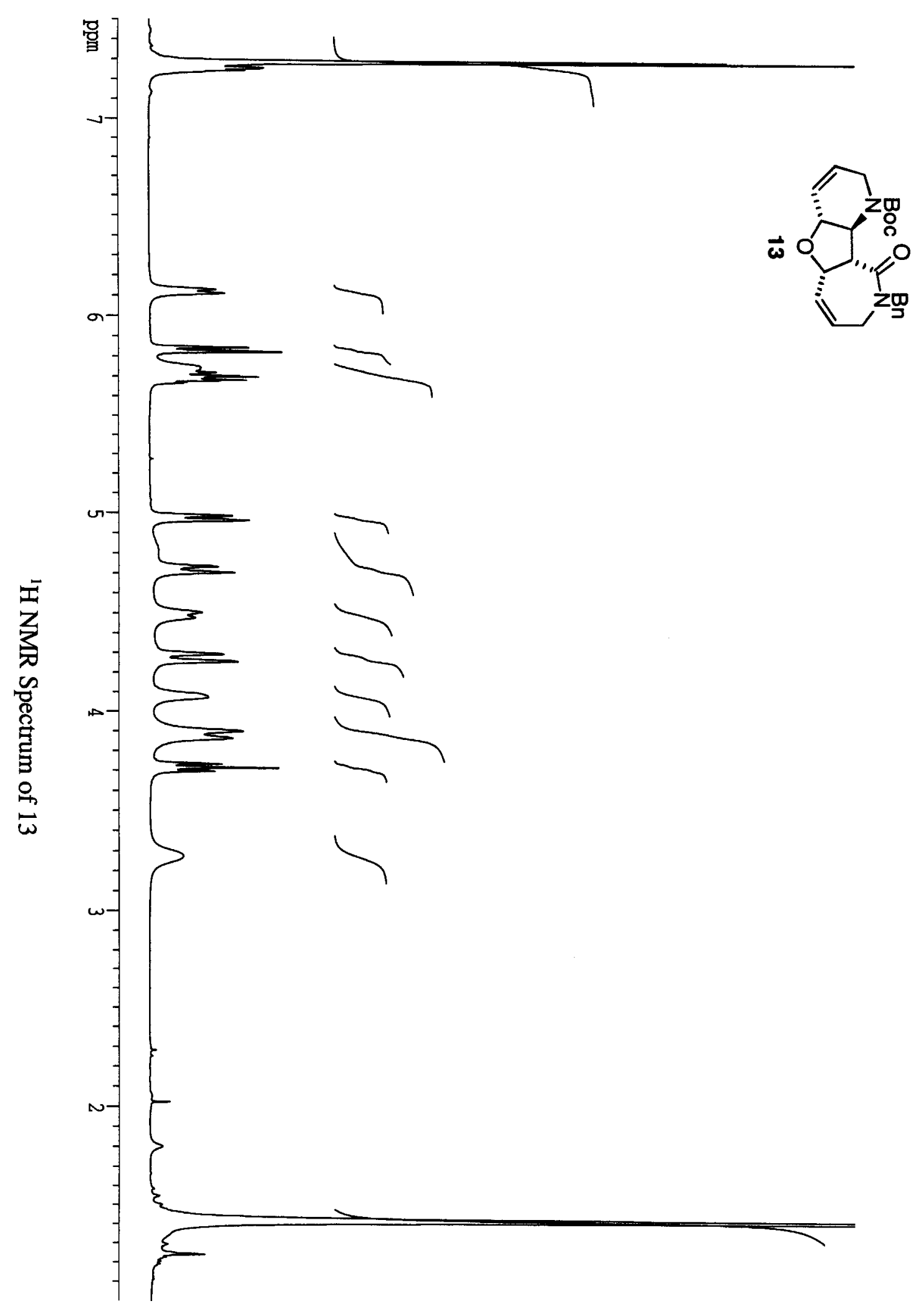




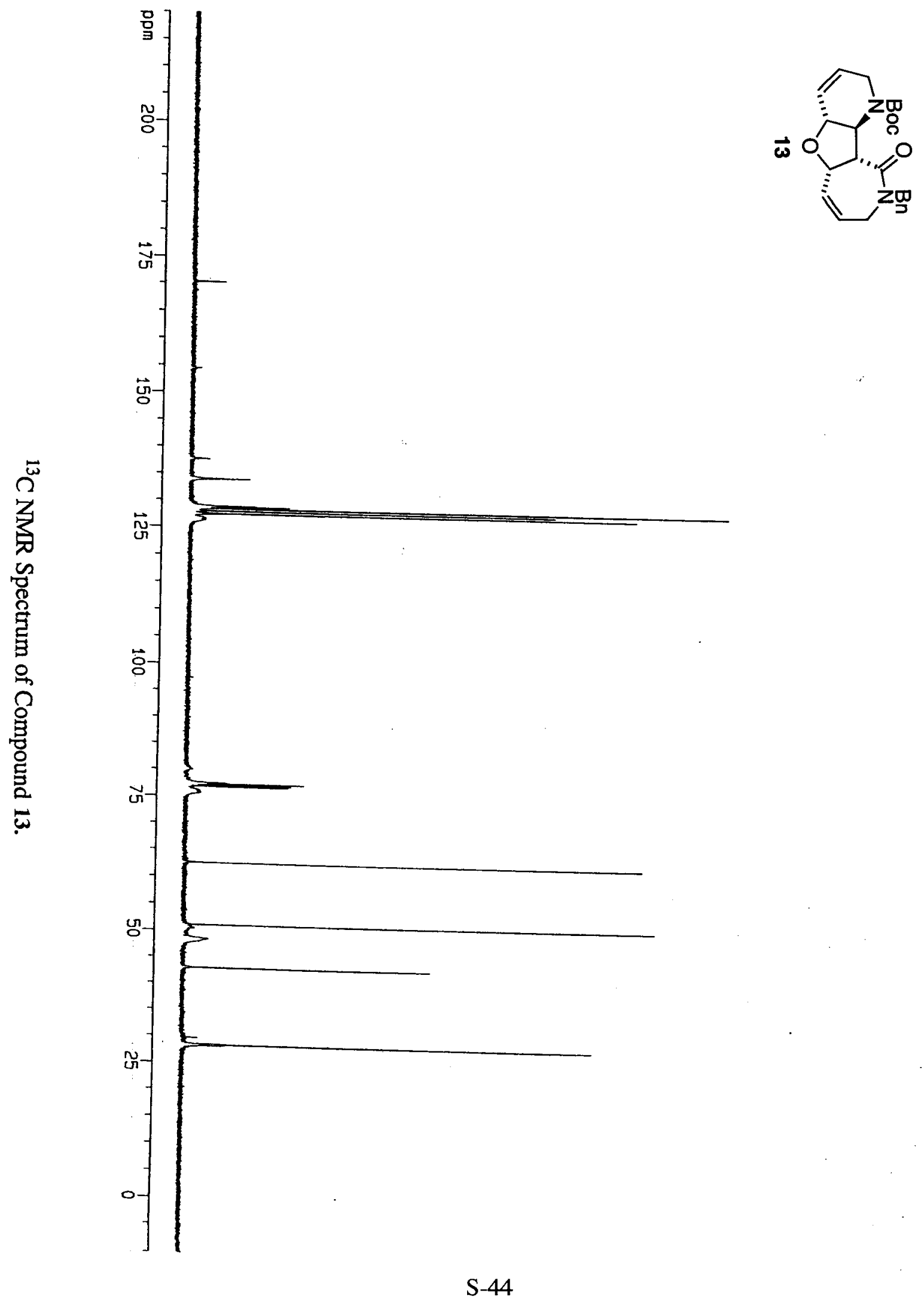




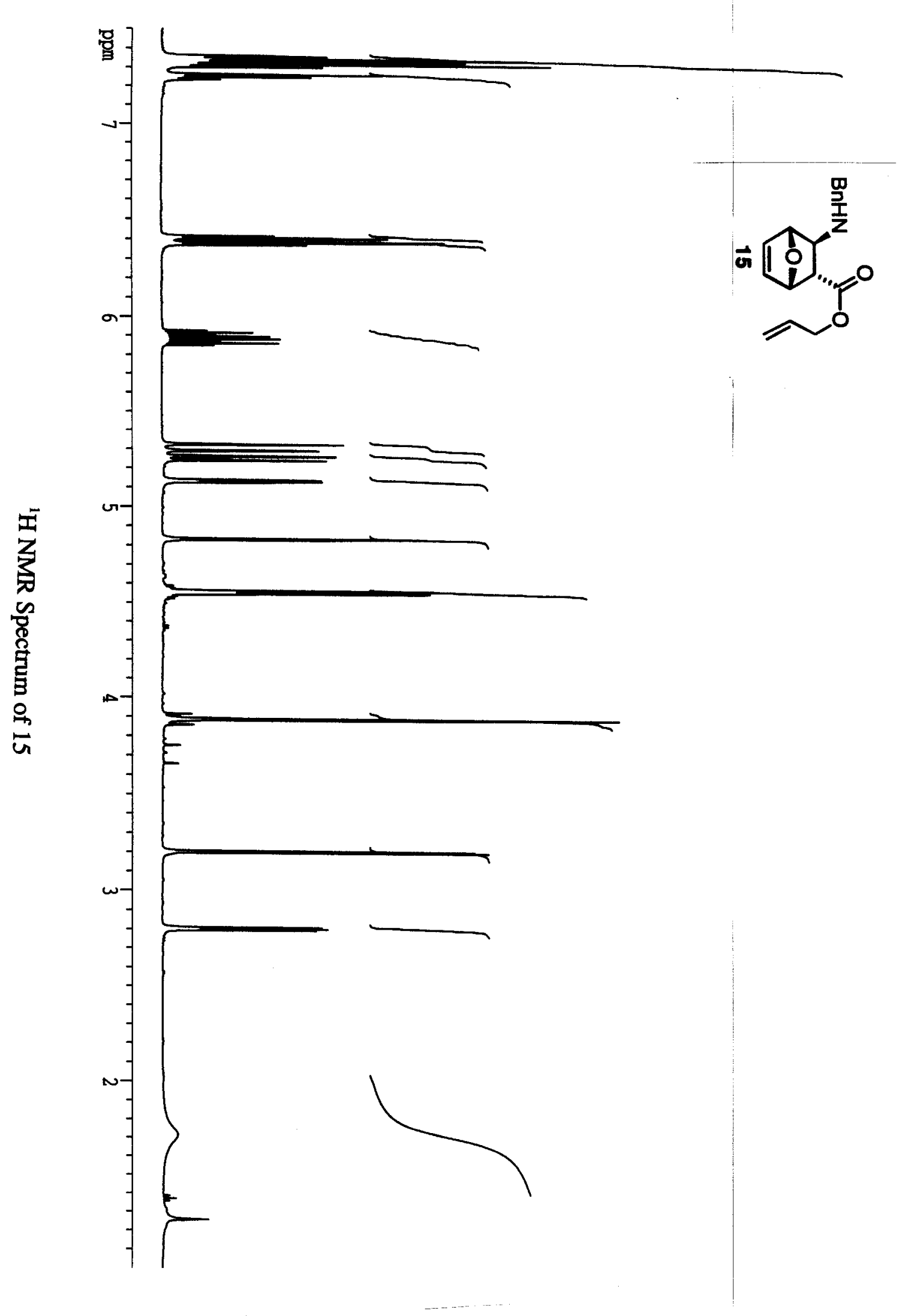




$$
\mid
$$




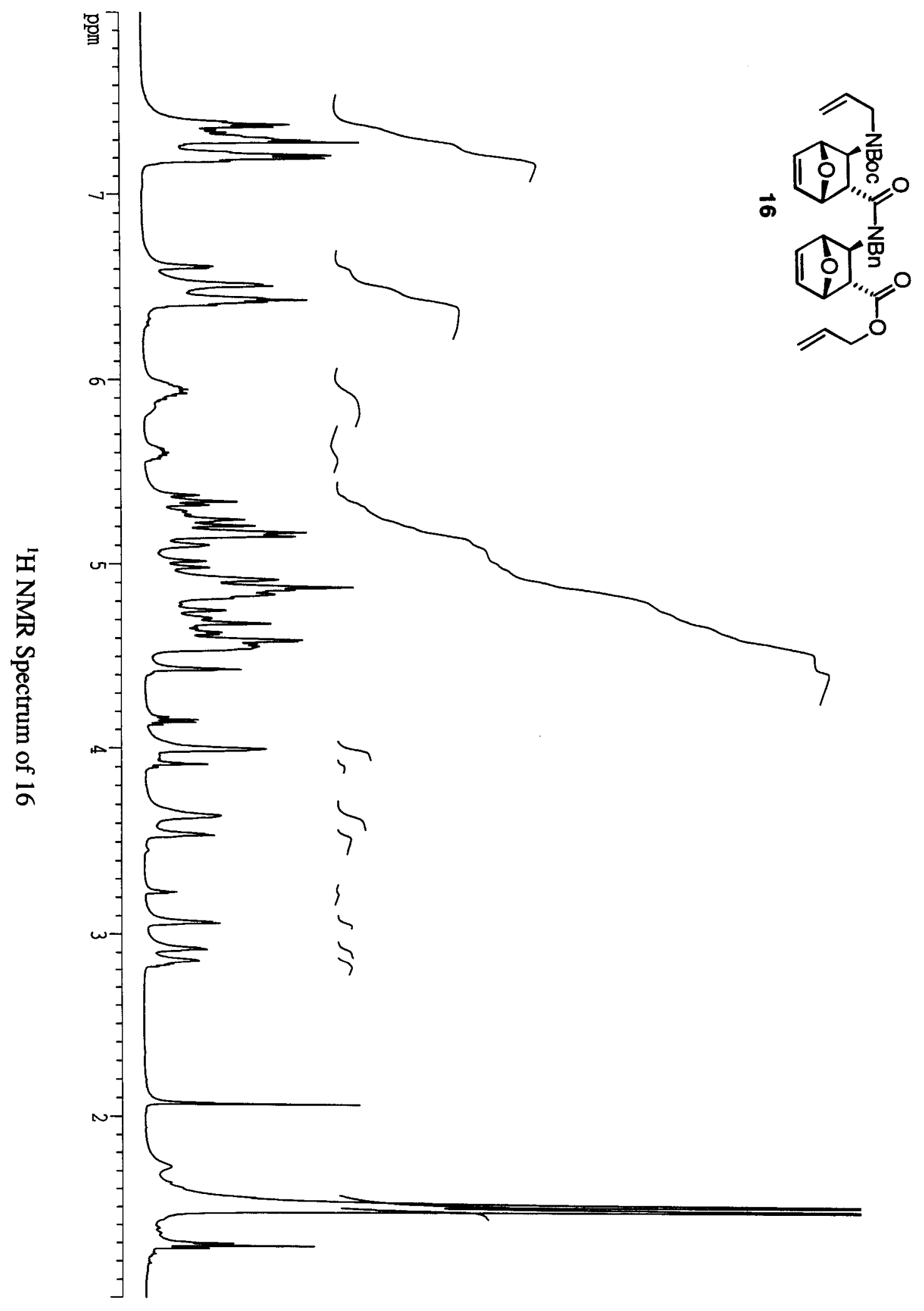




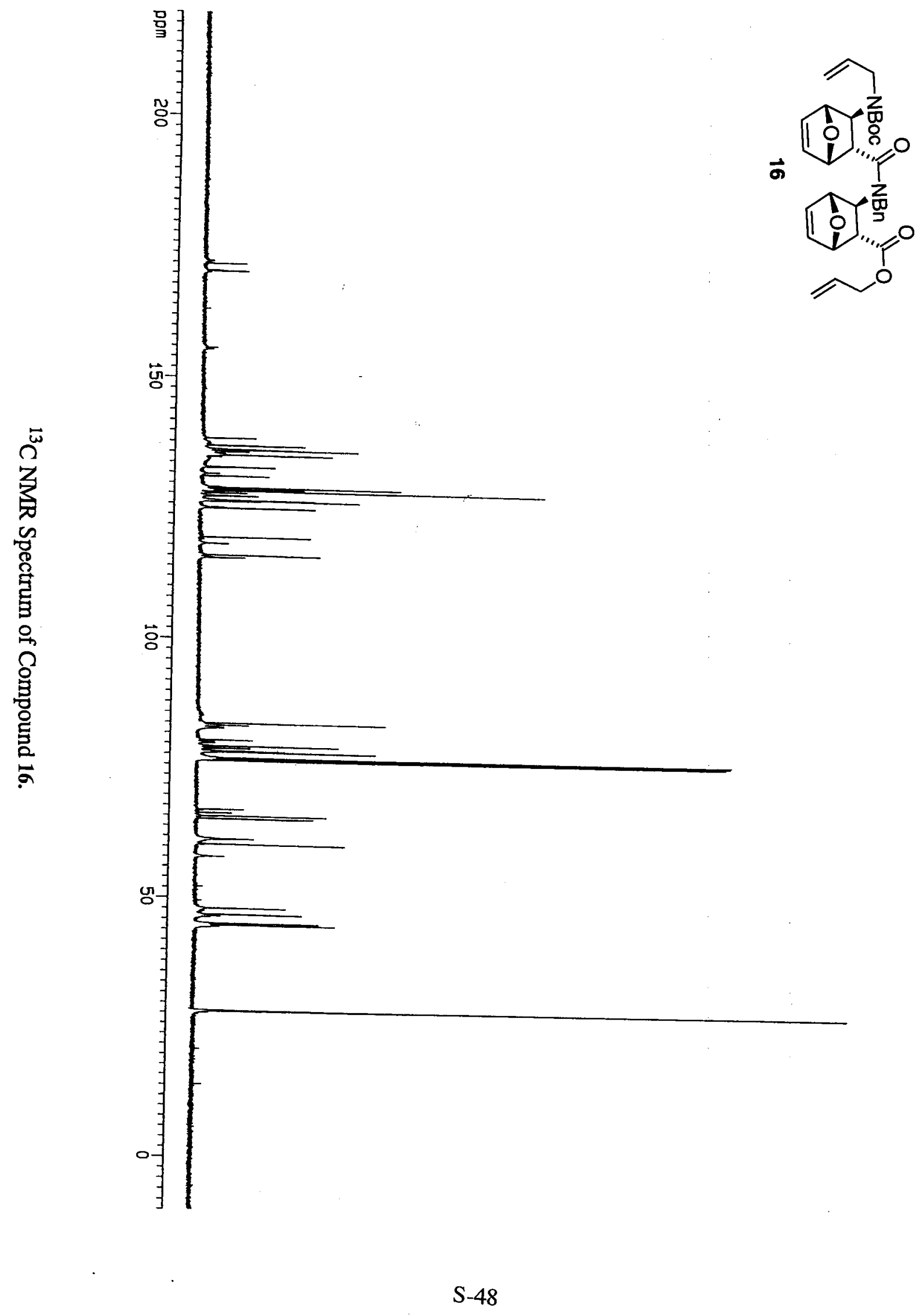




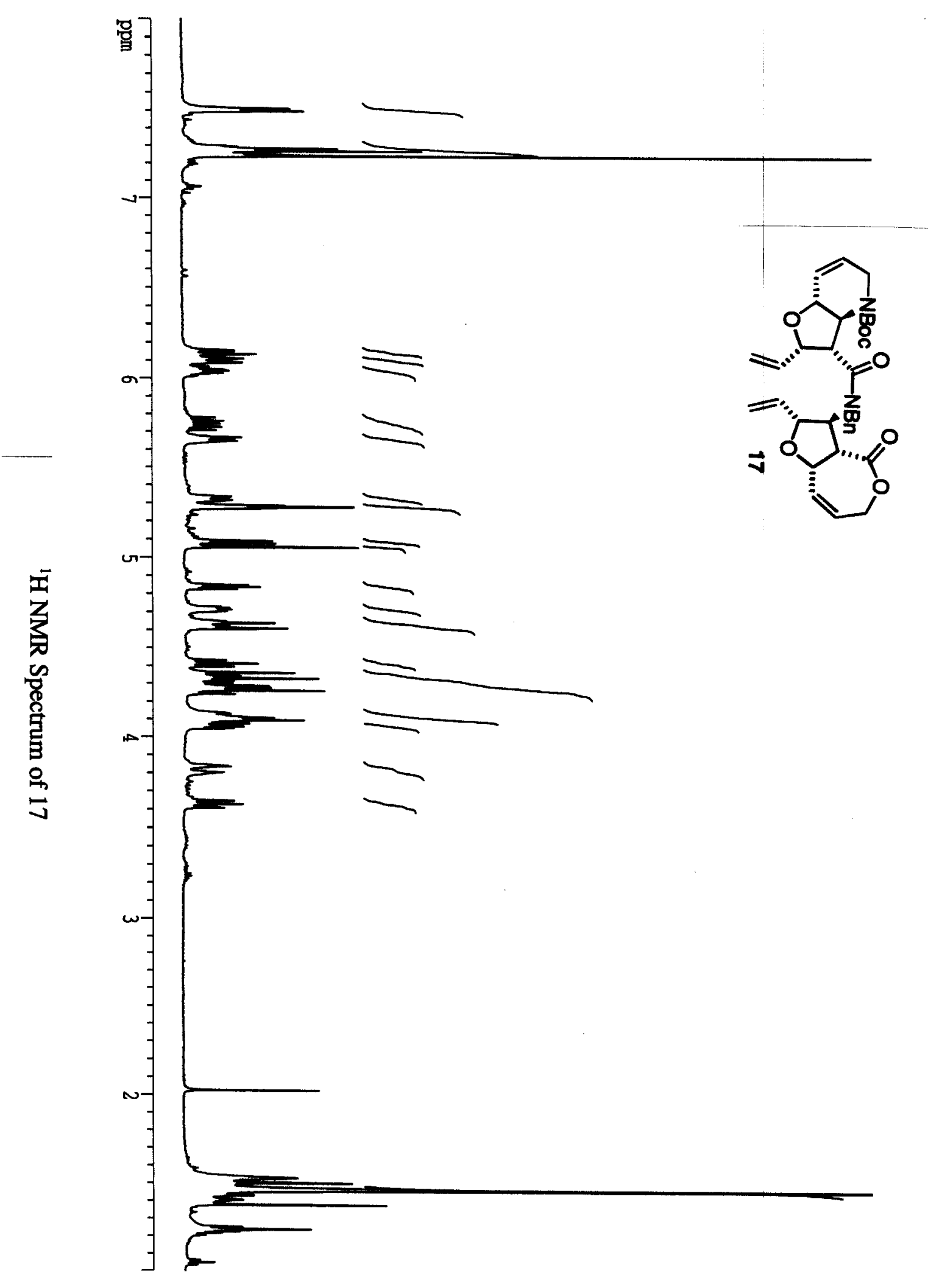




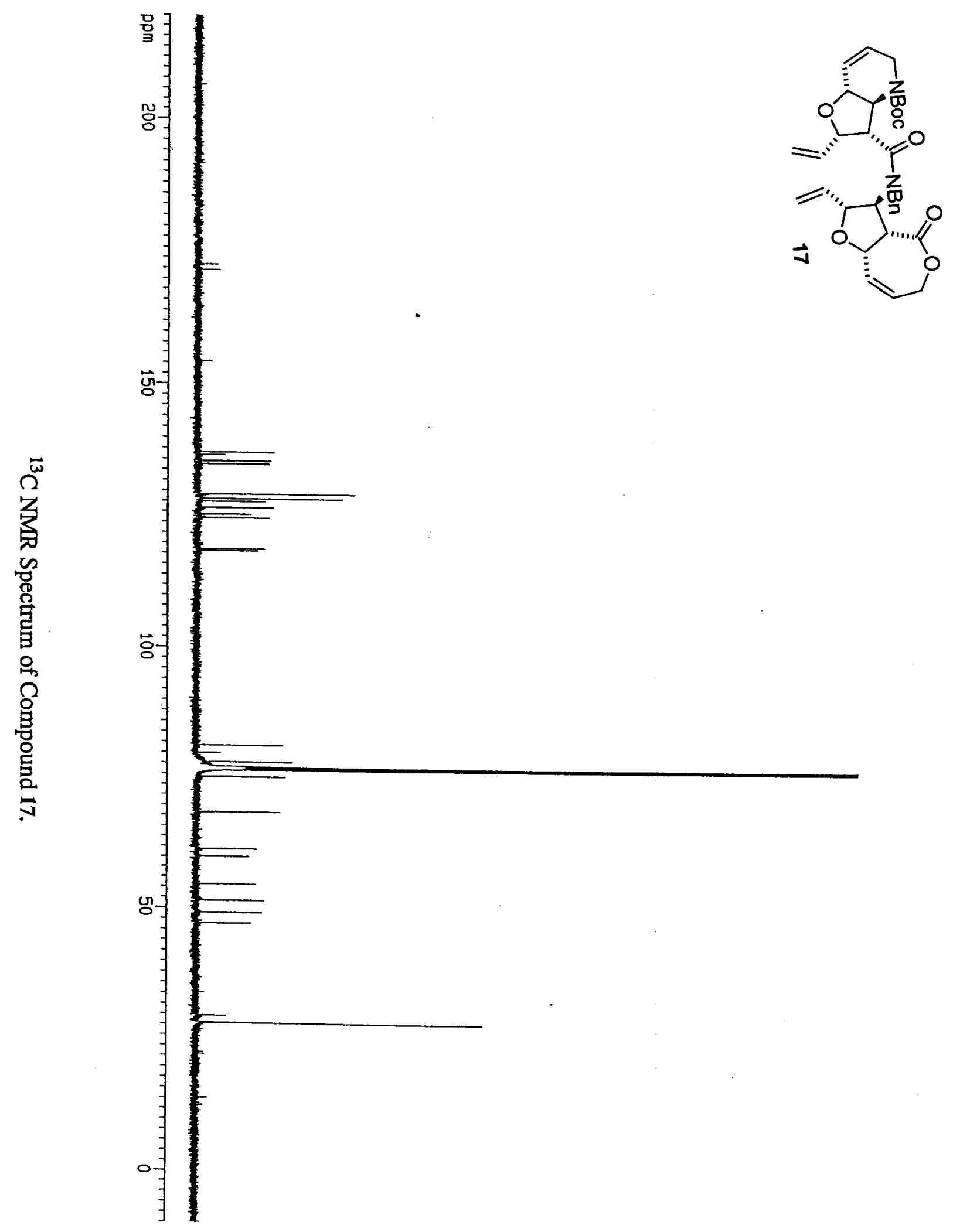




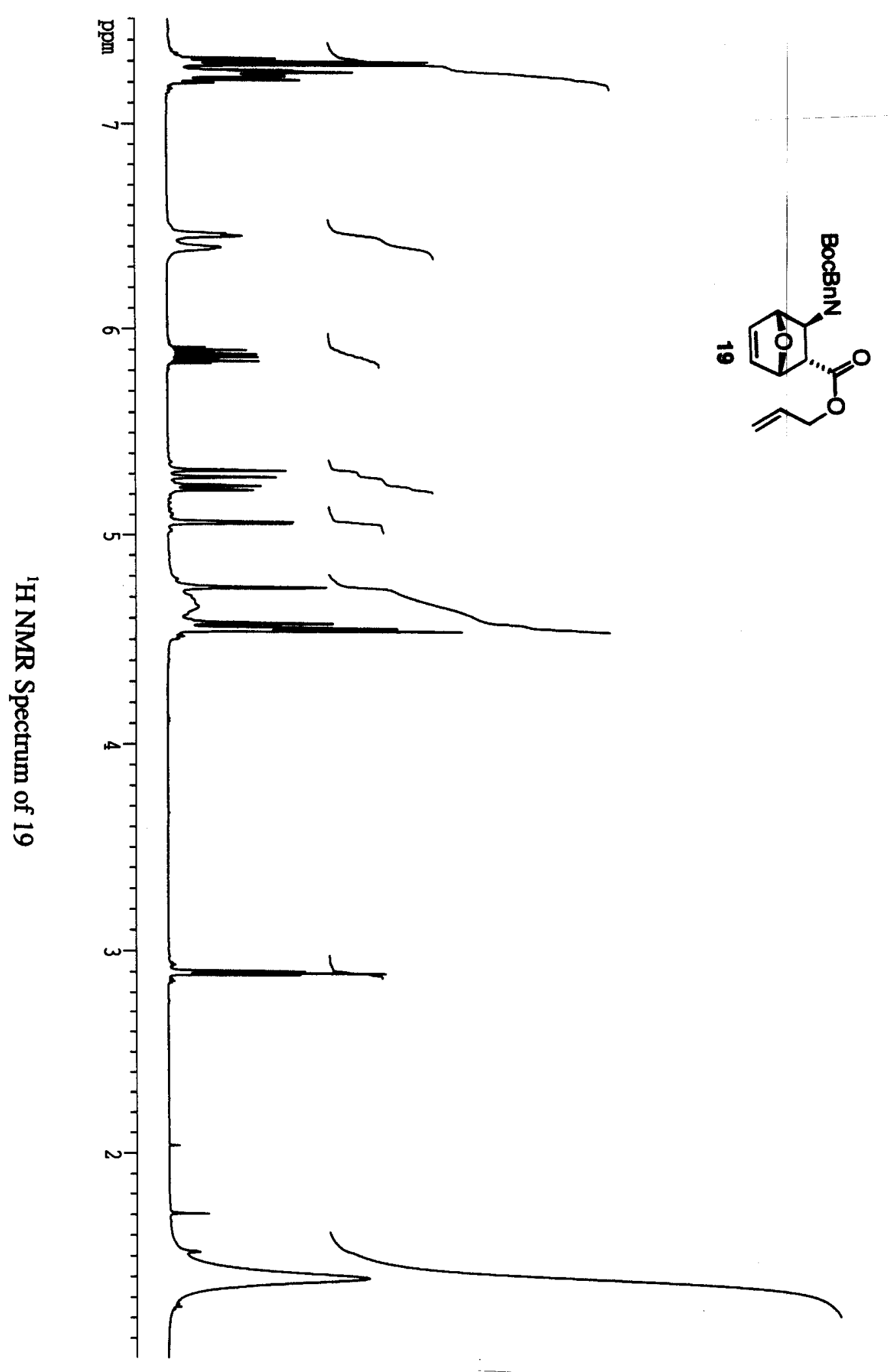

S51 


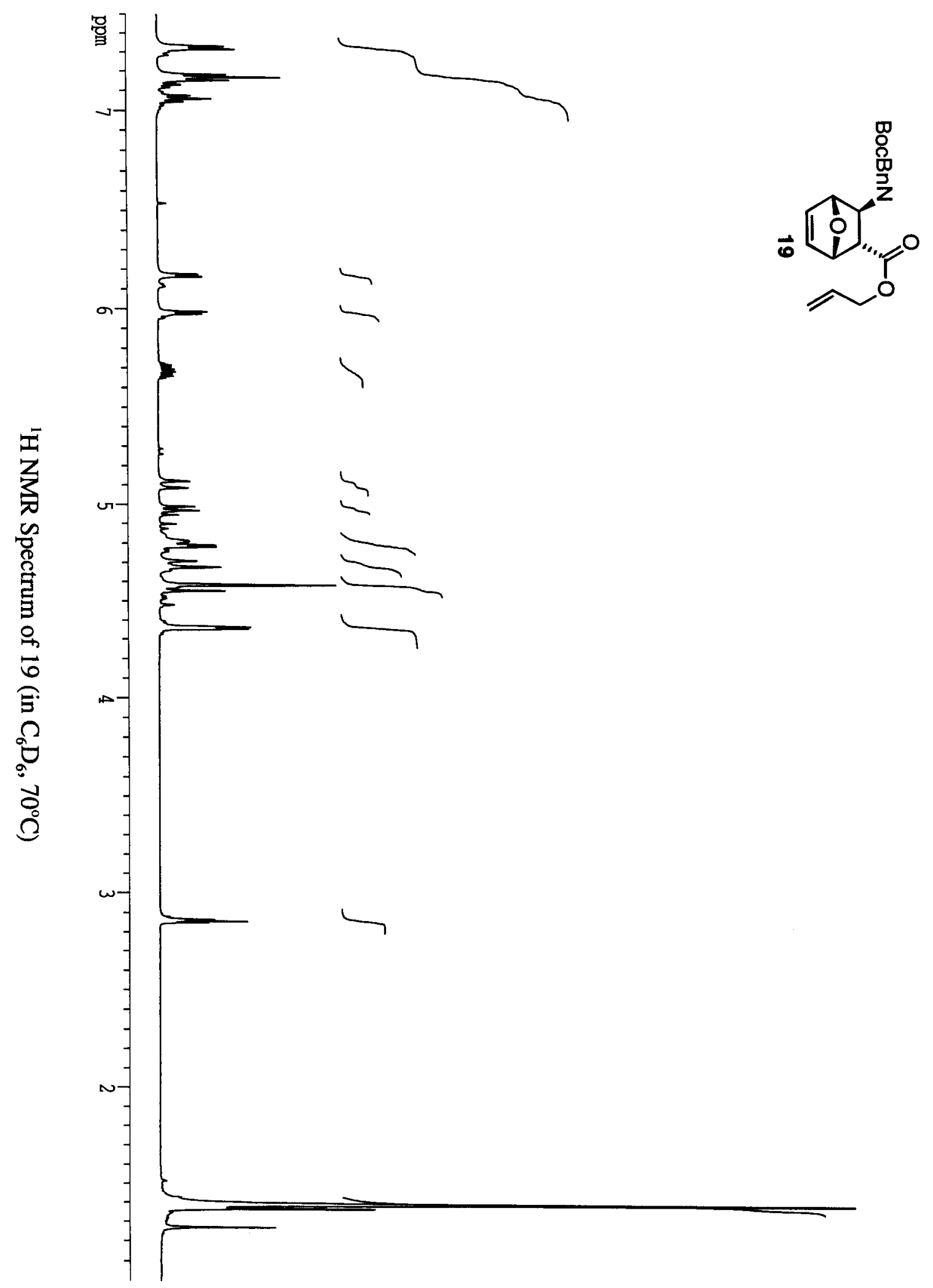




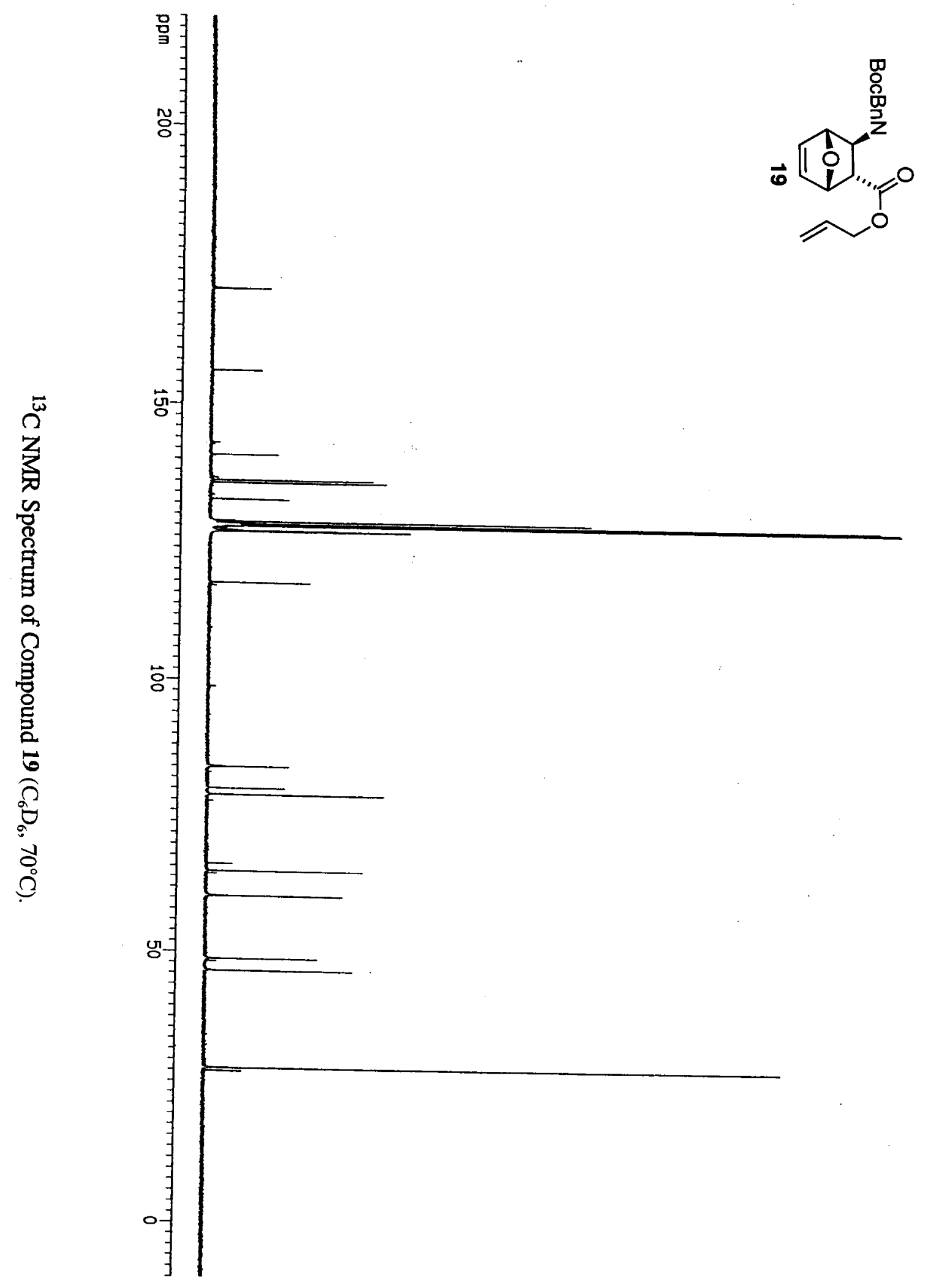




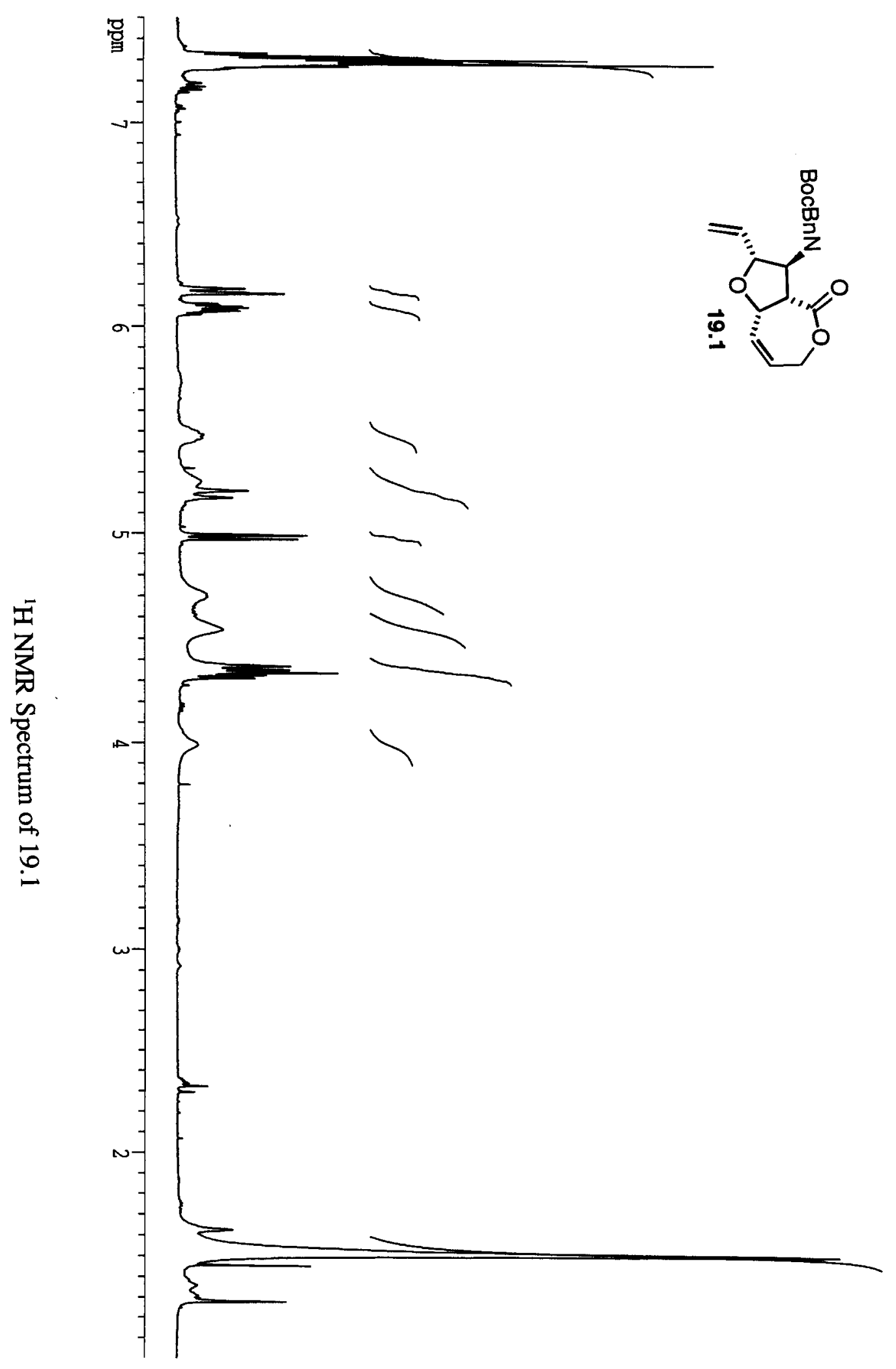




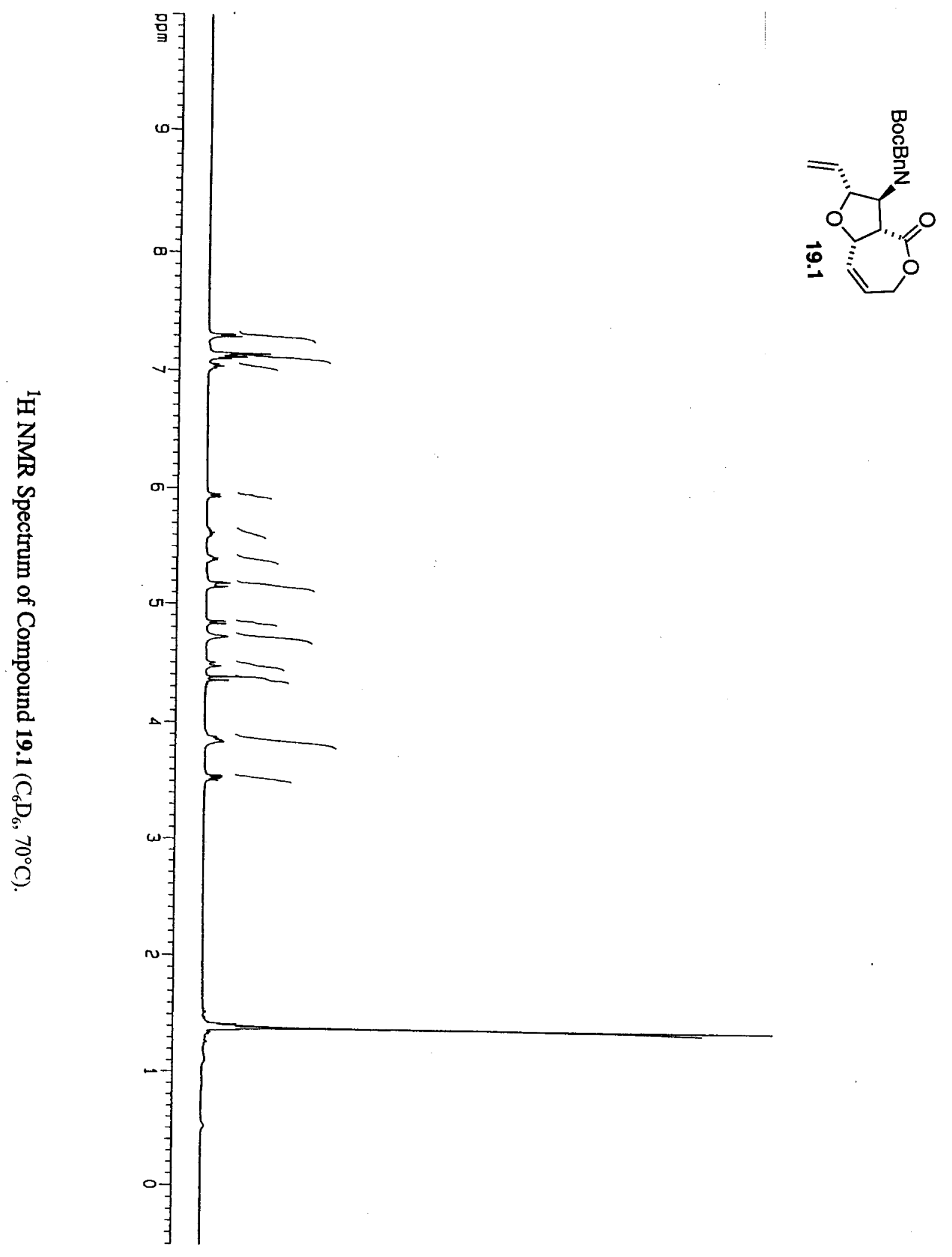




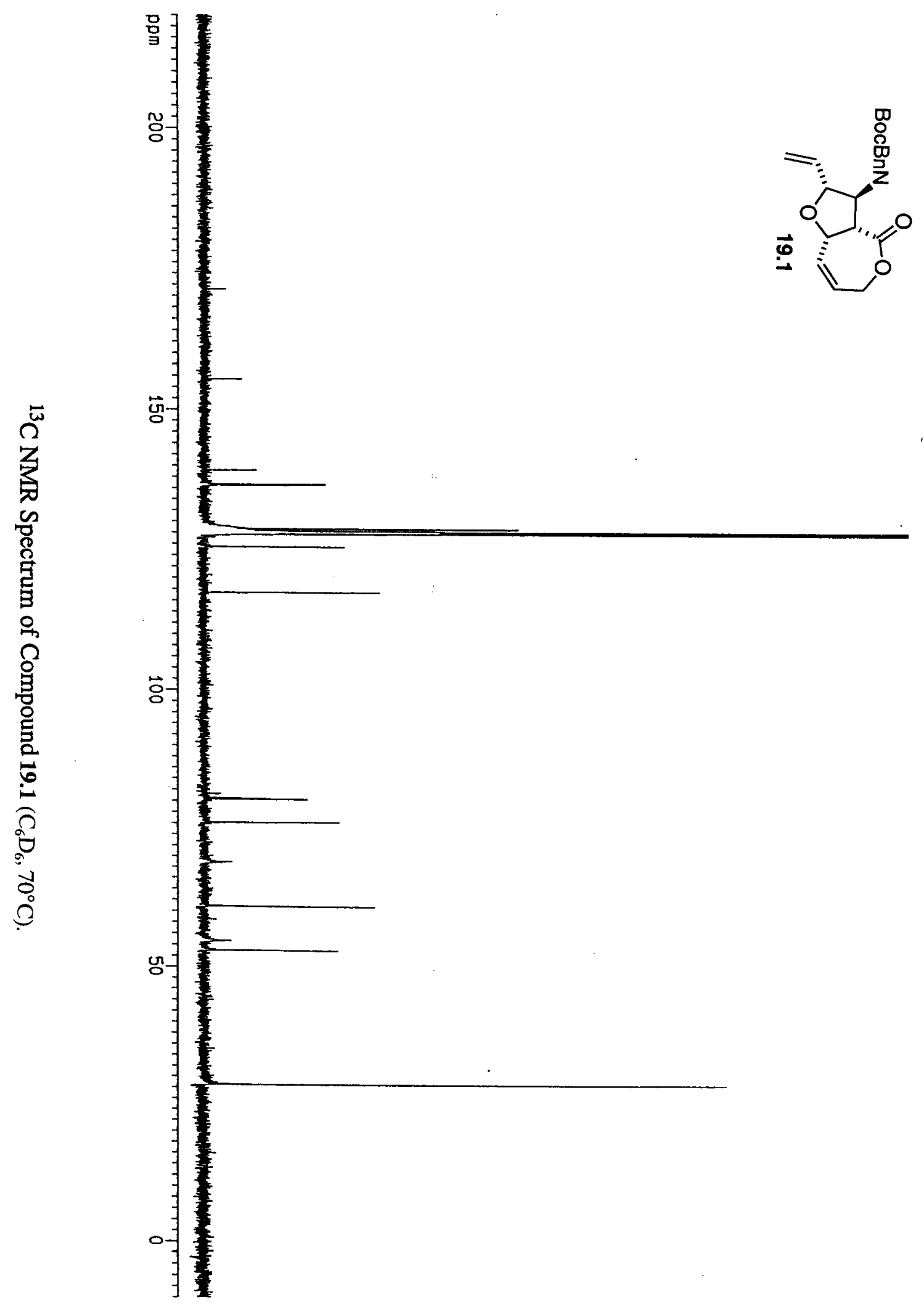

S-56 


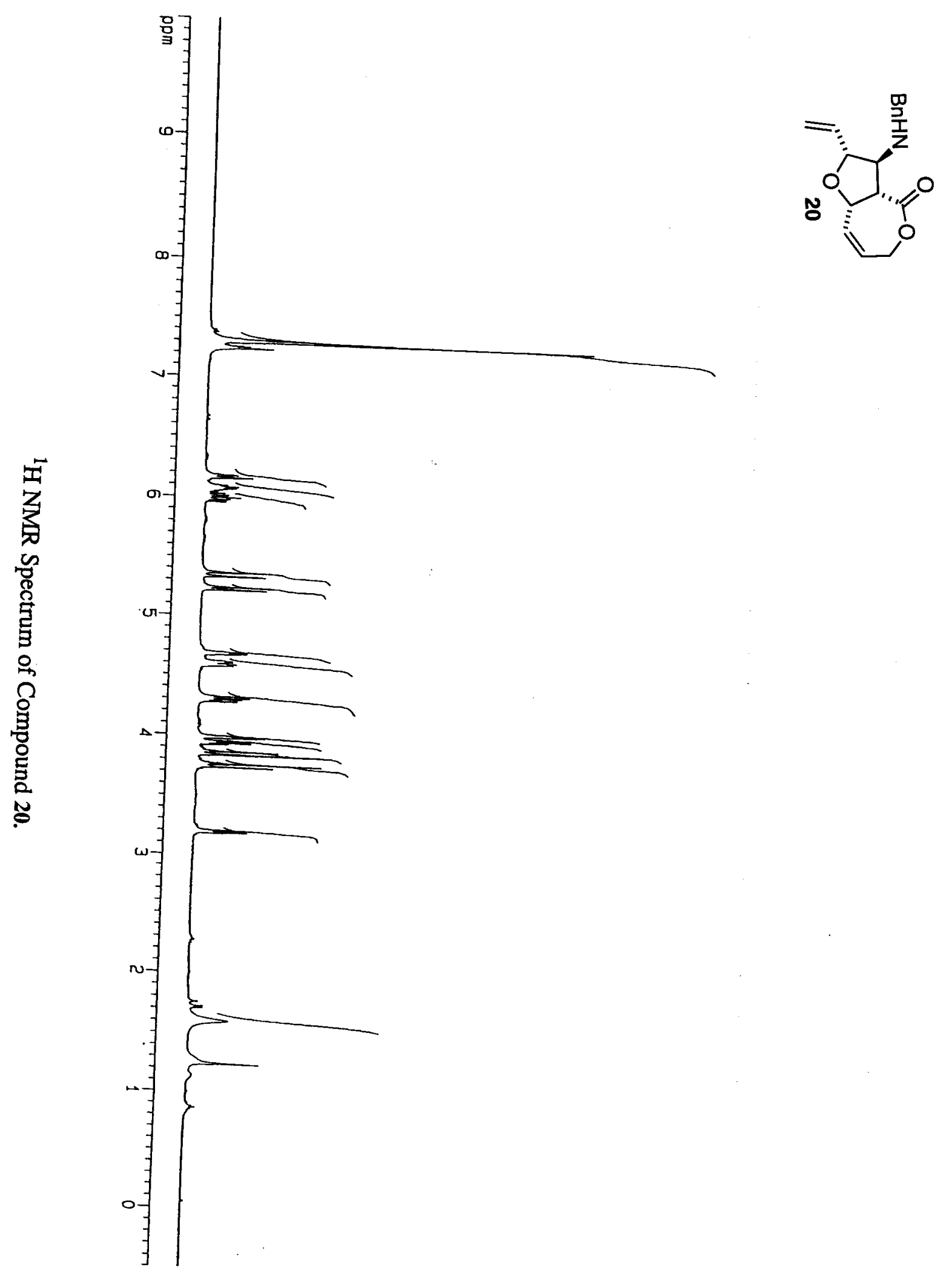




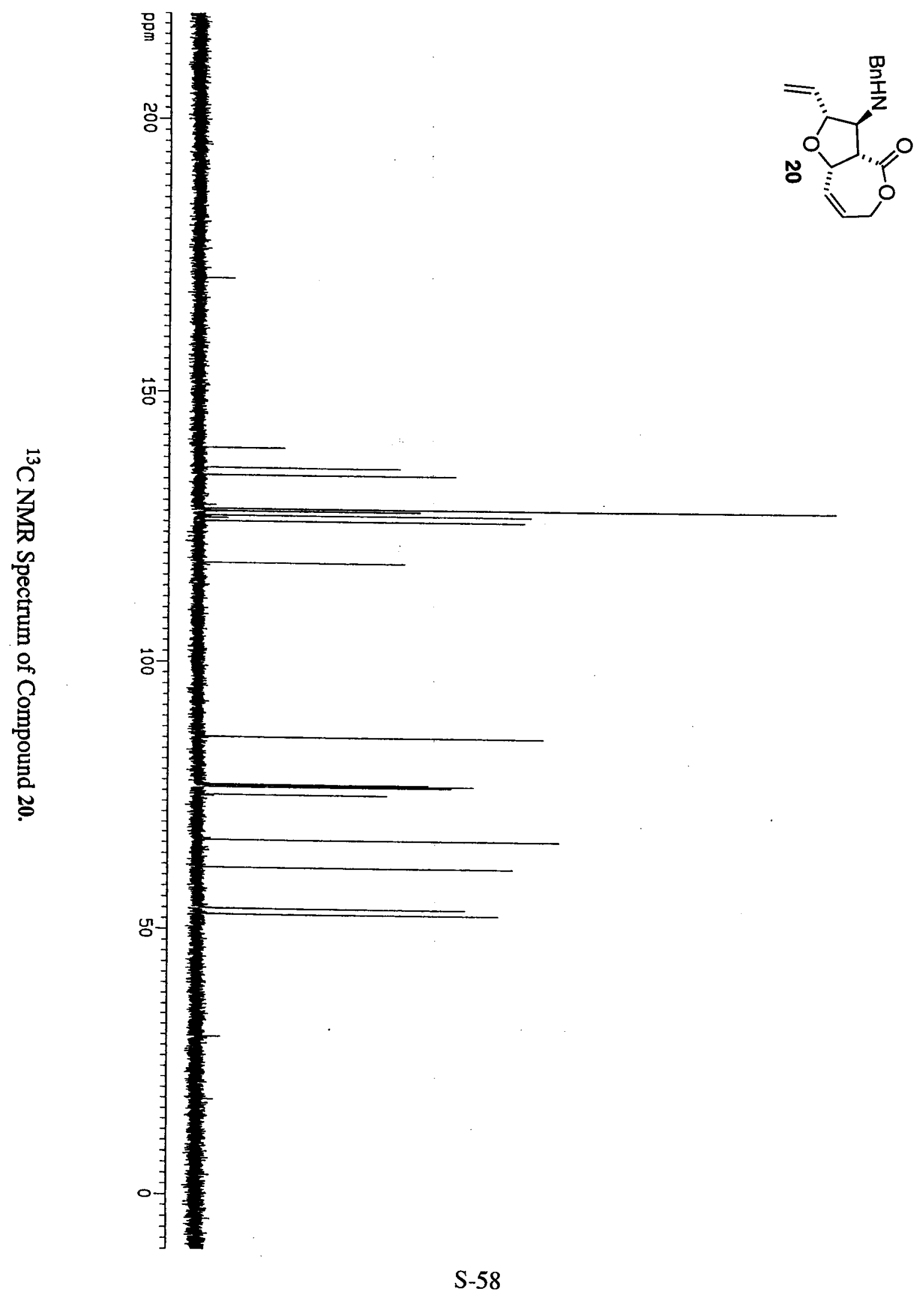




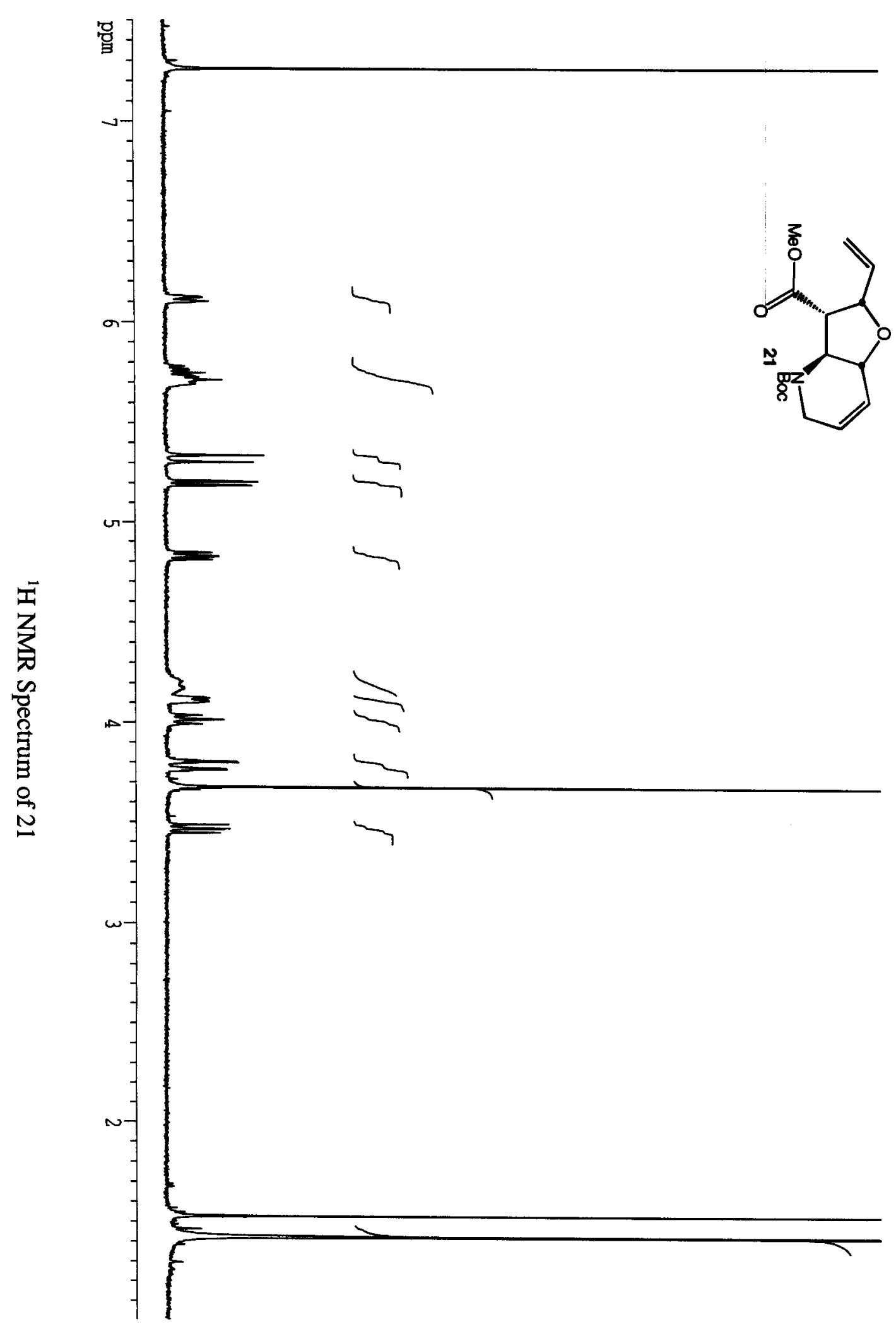




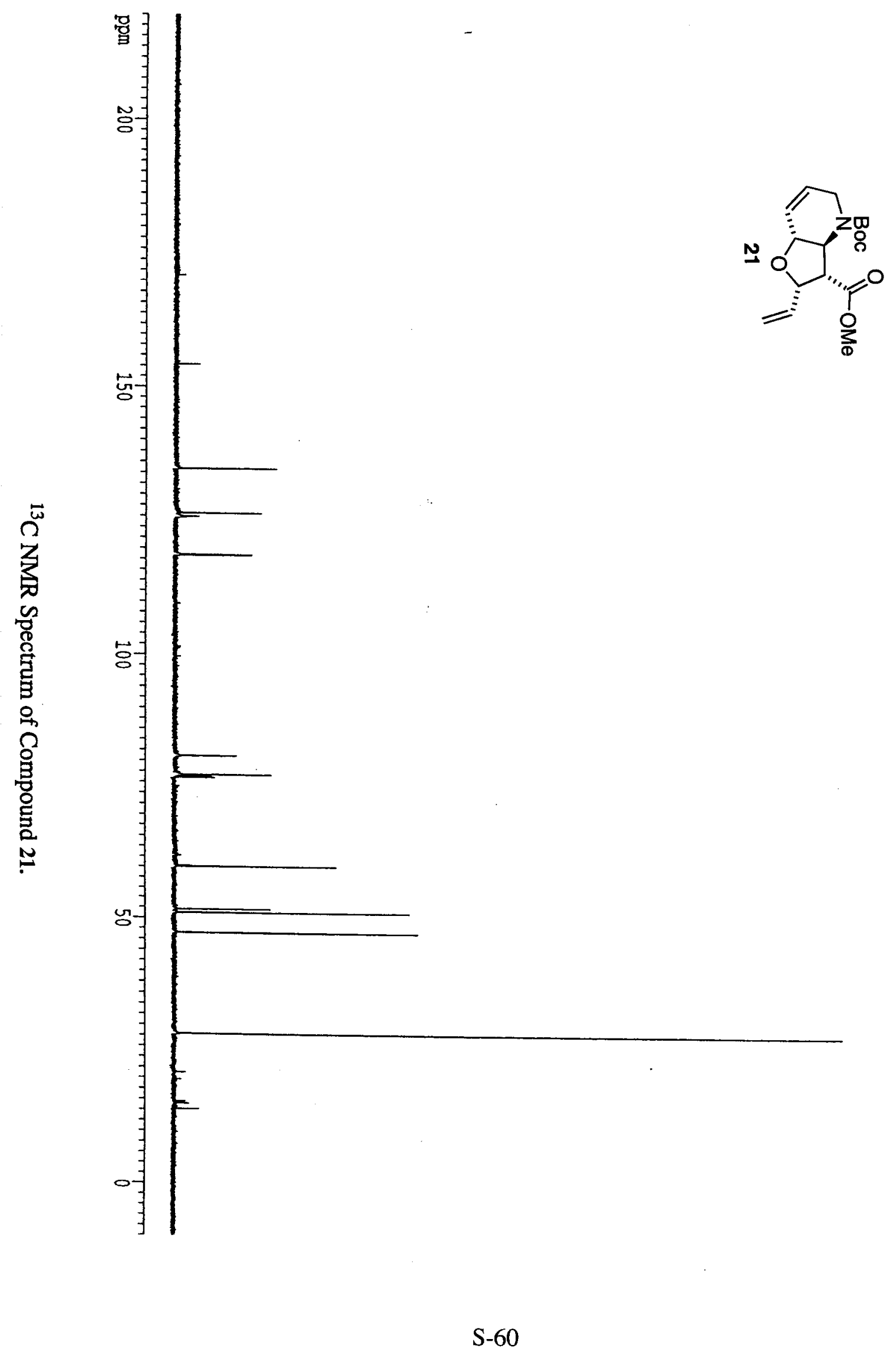




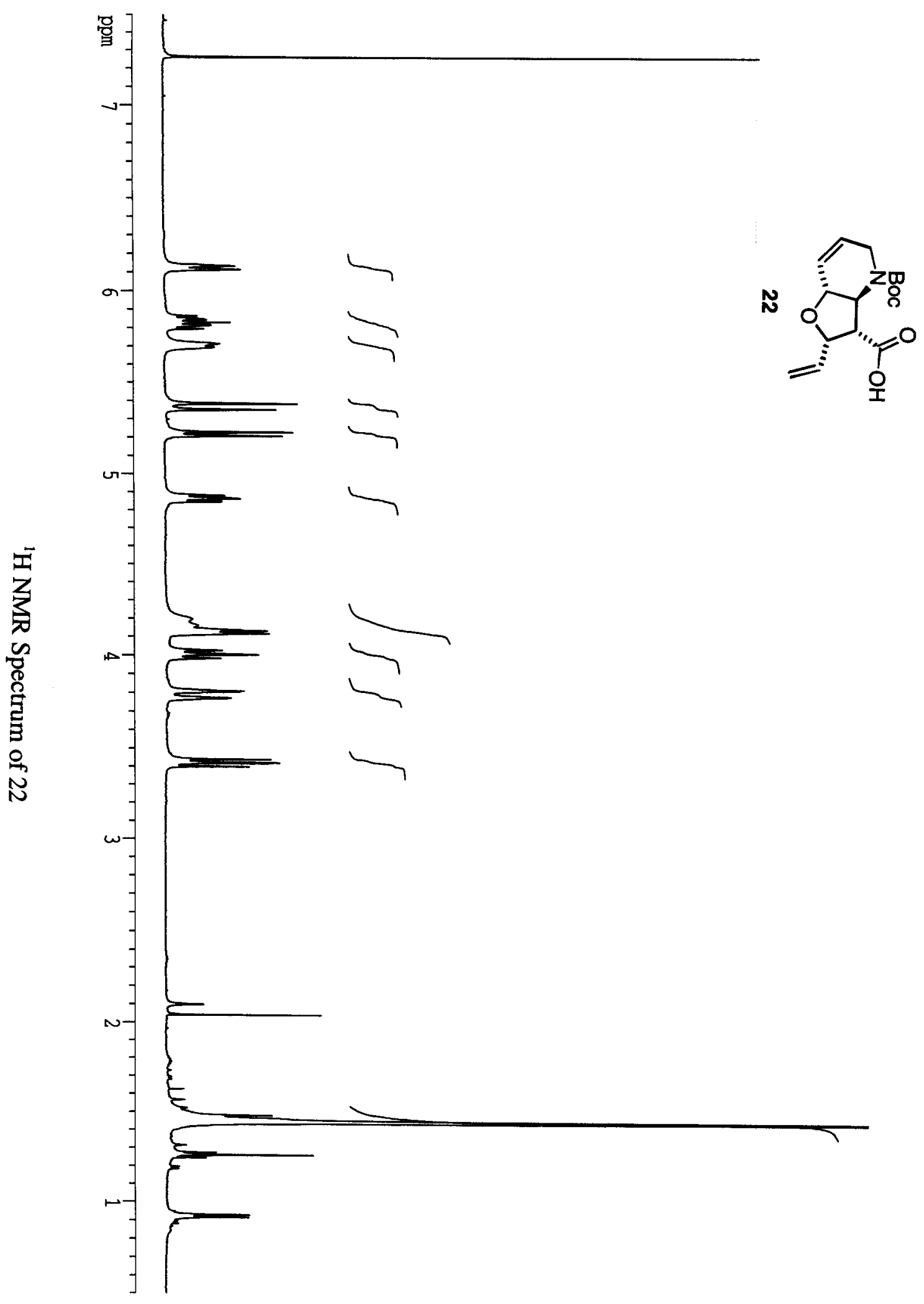




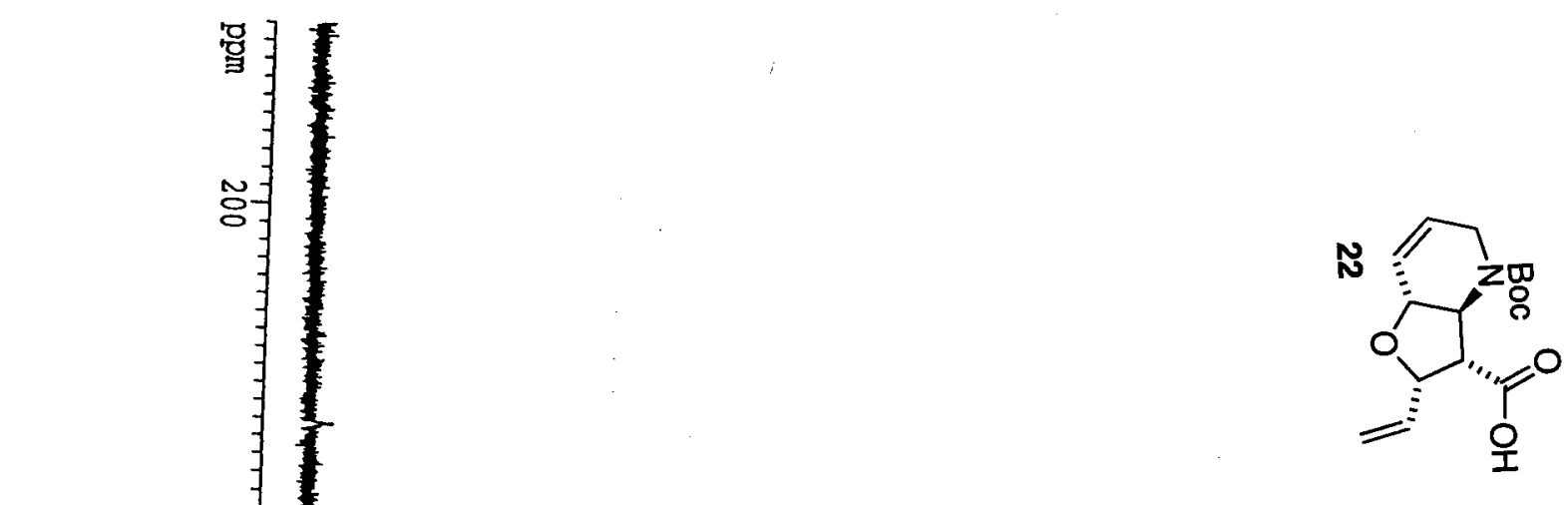




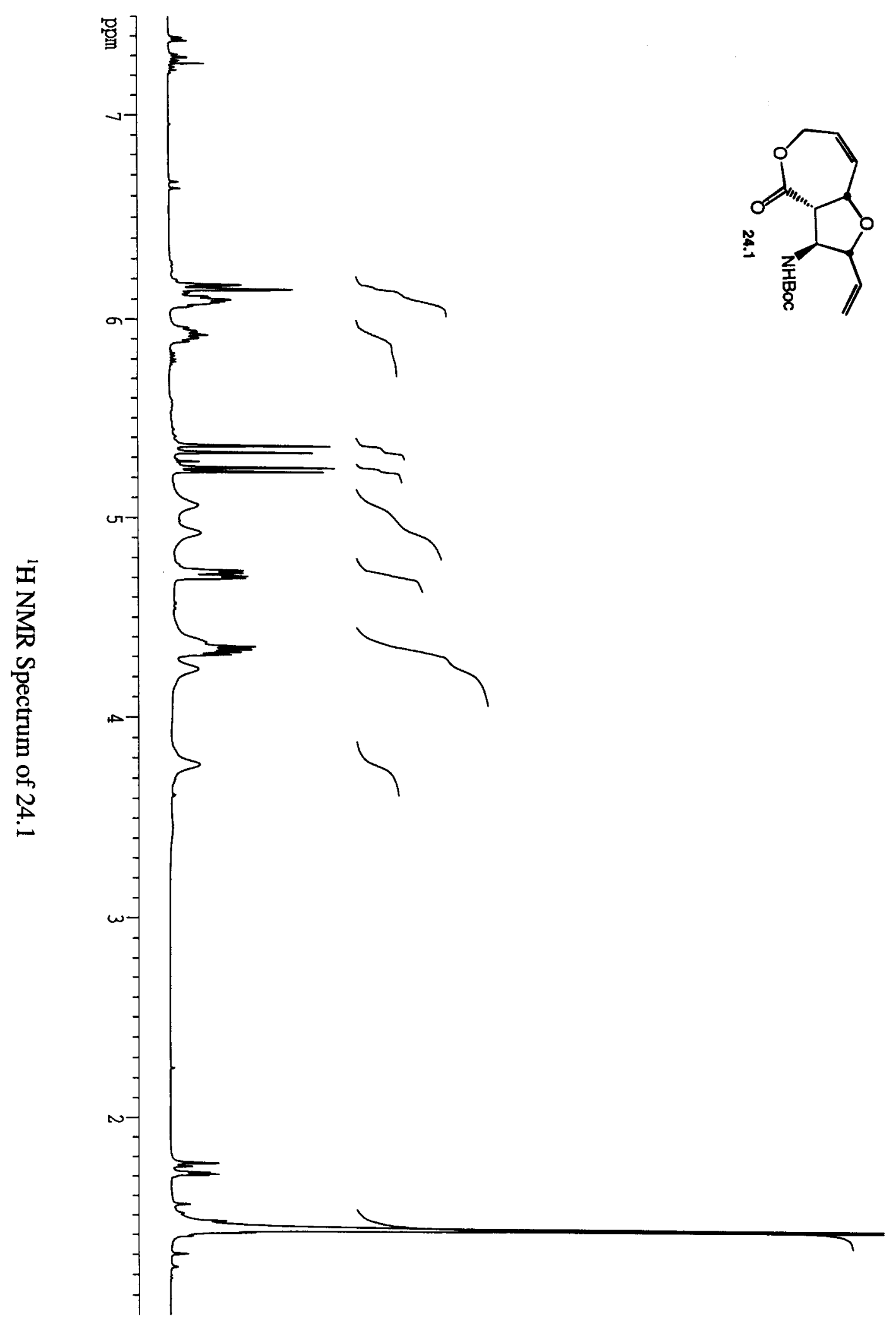

S63 


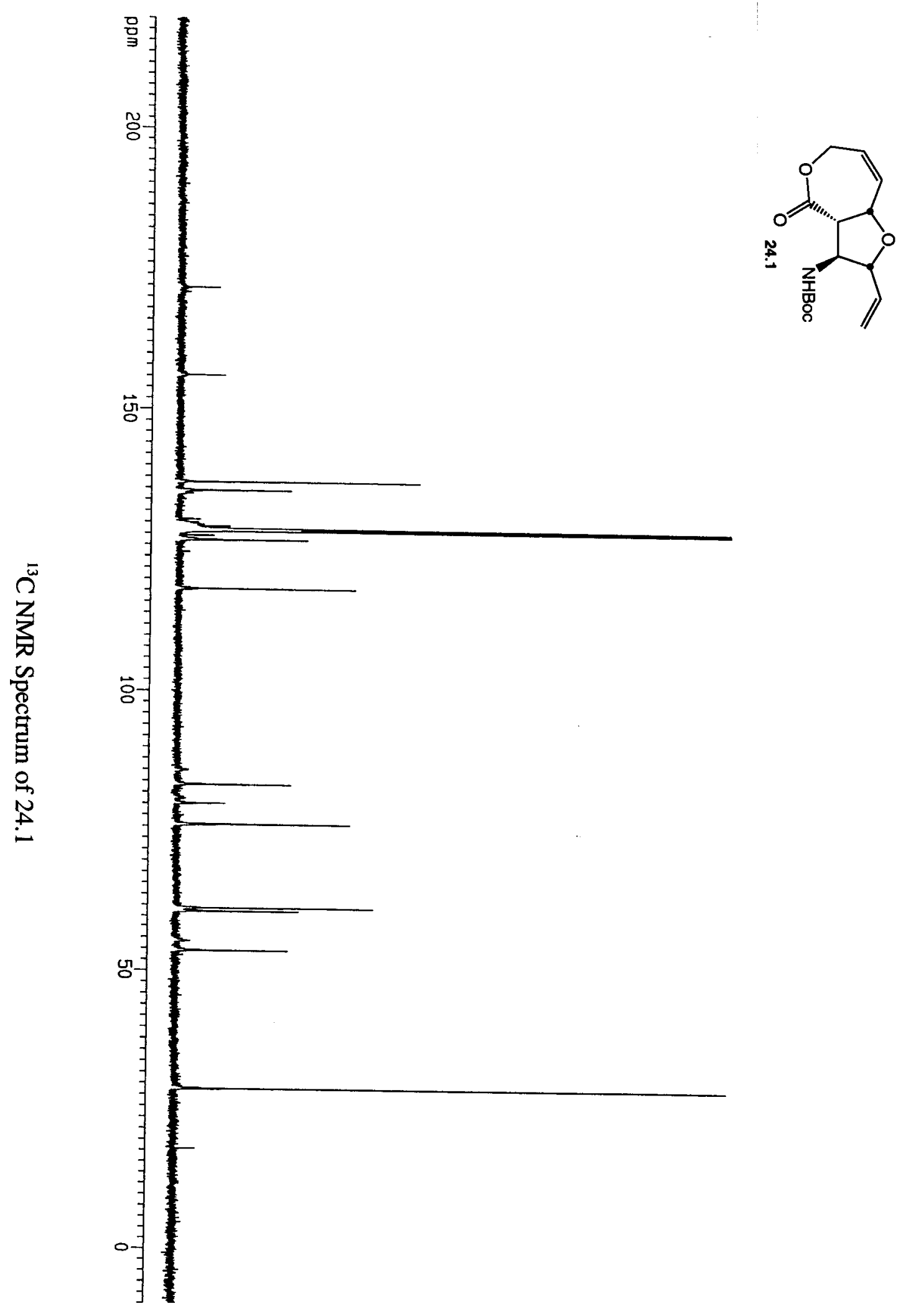




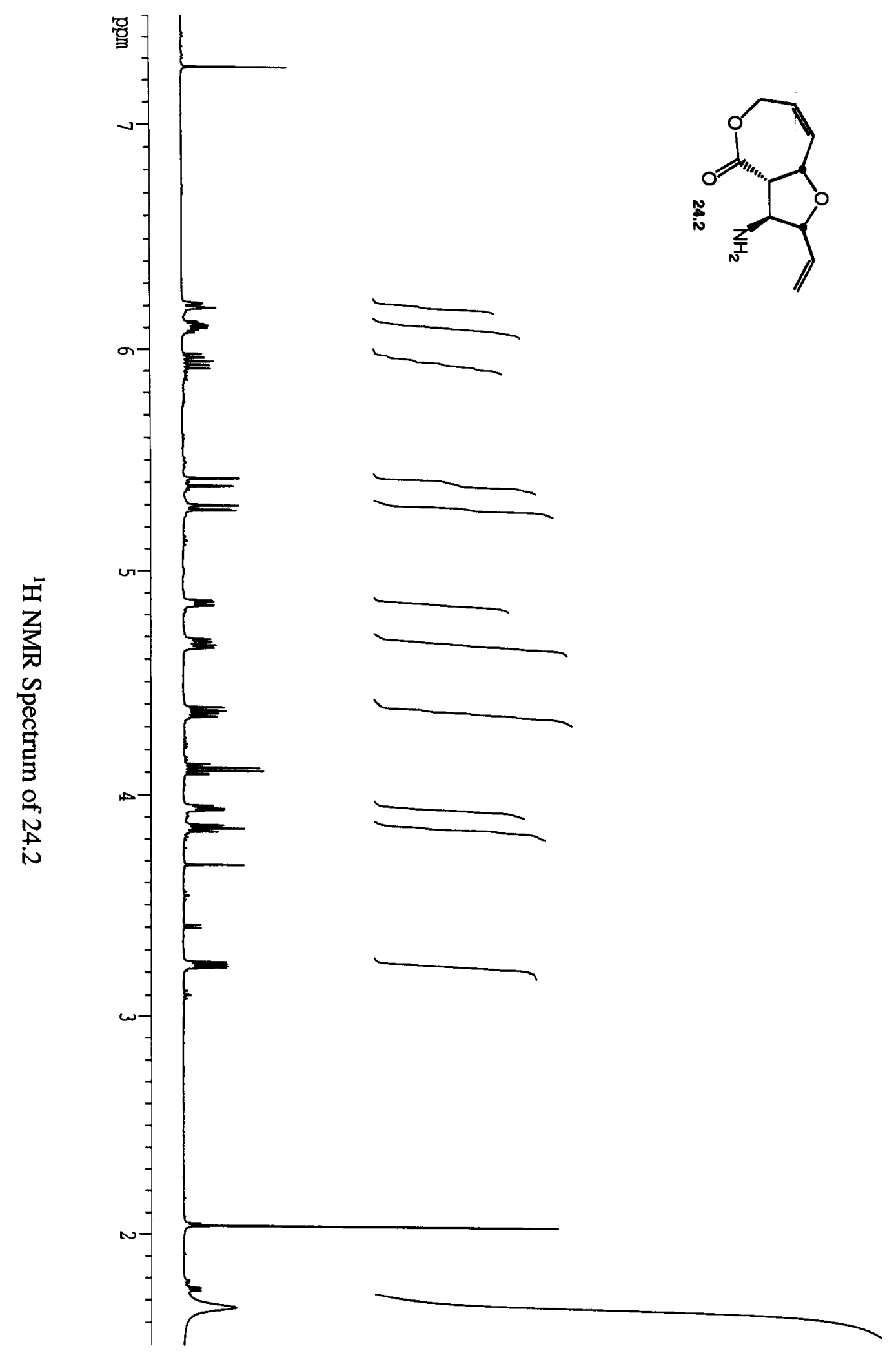




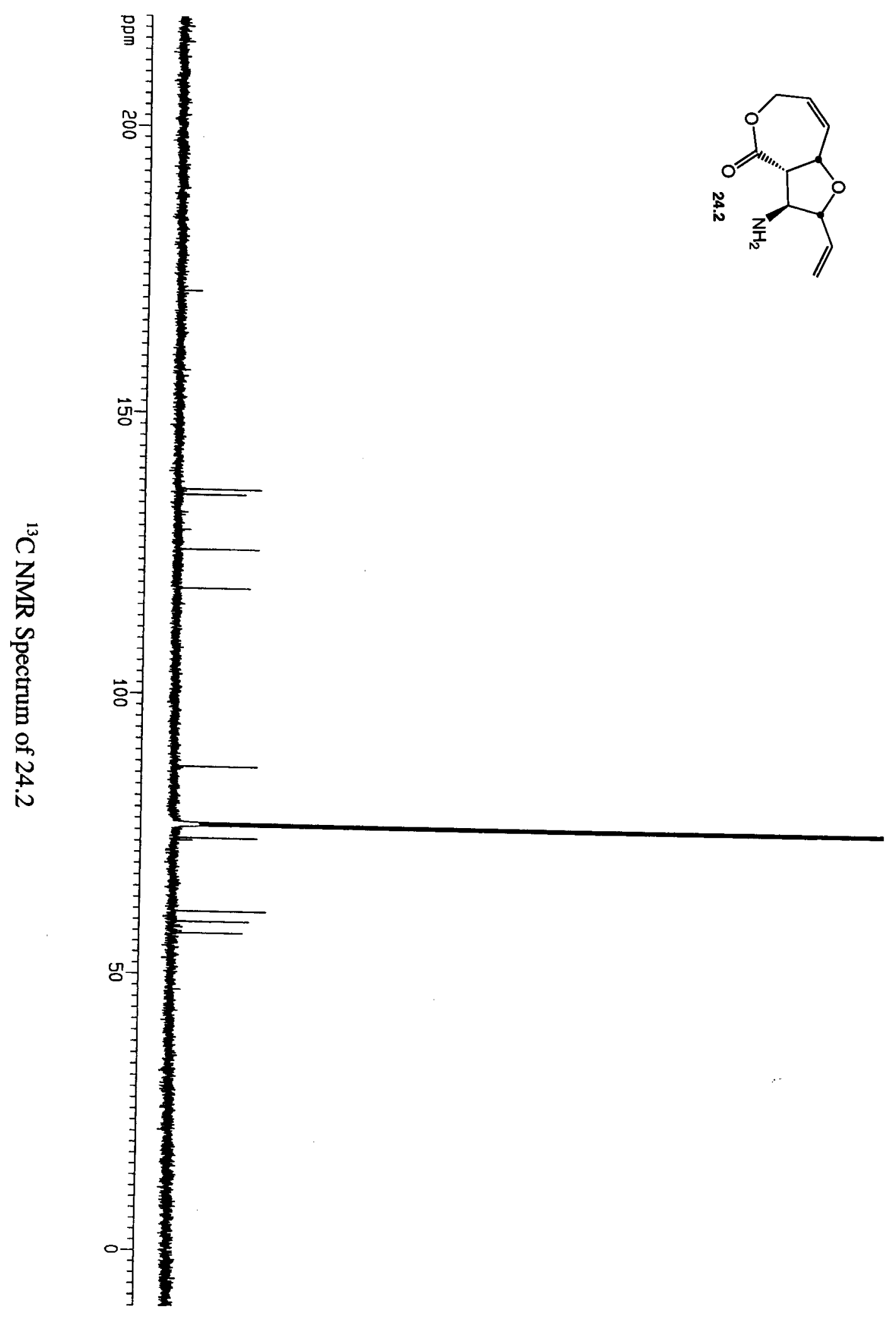

S-66 


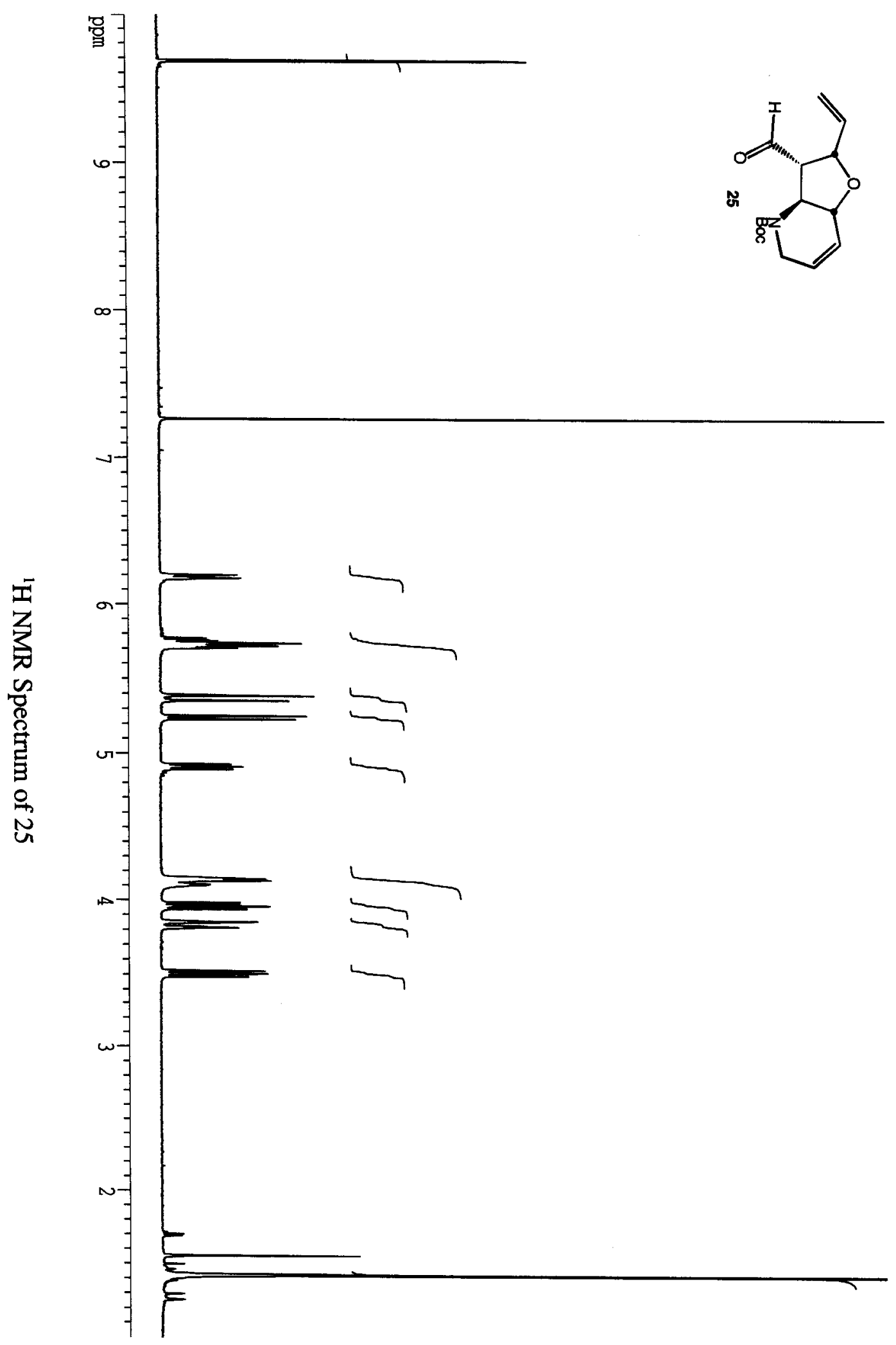




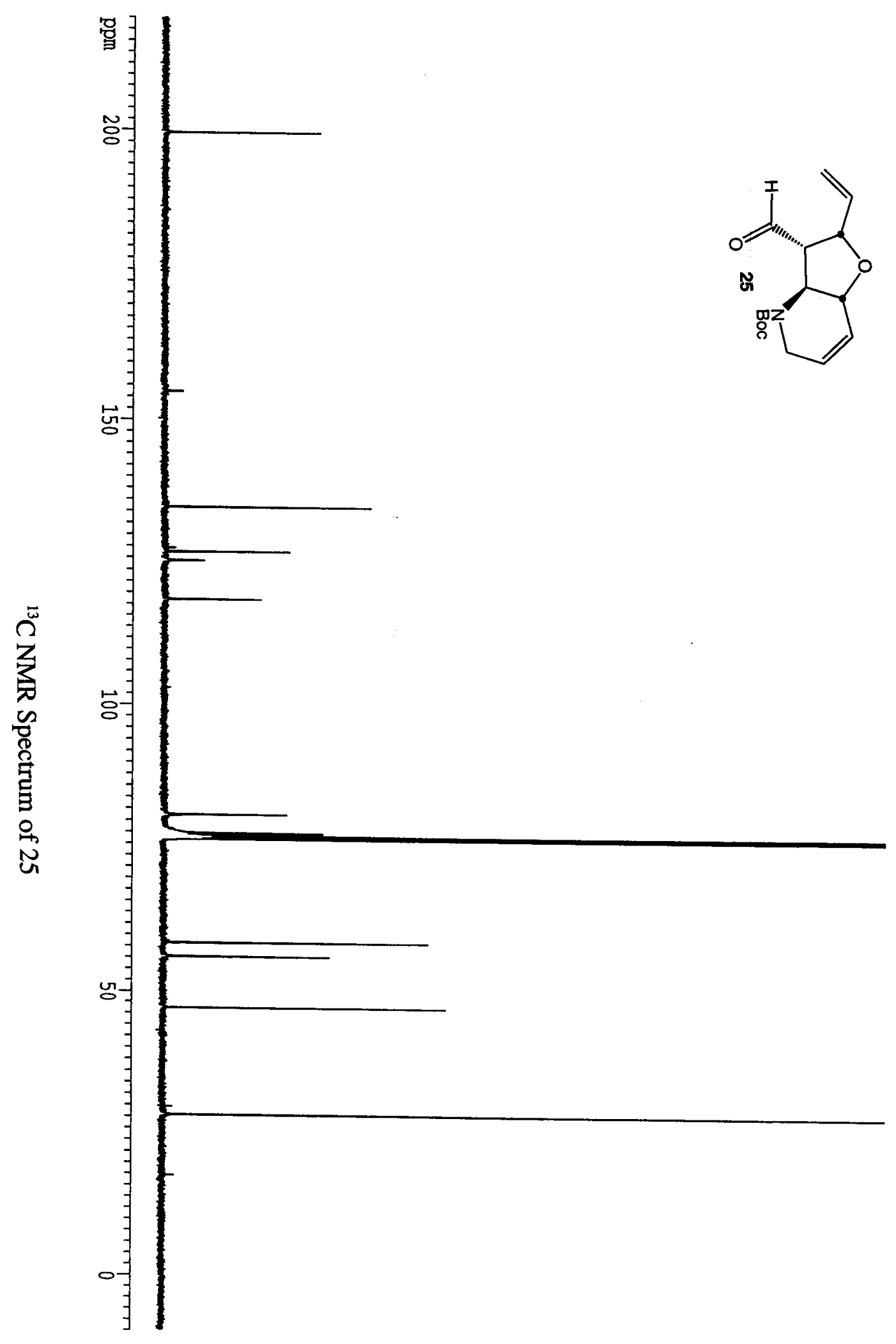




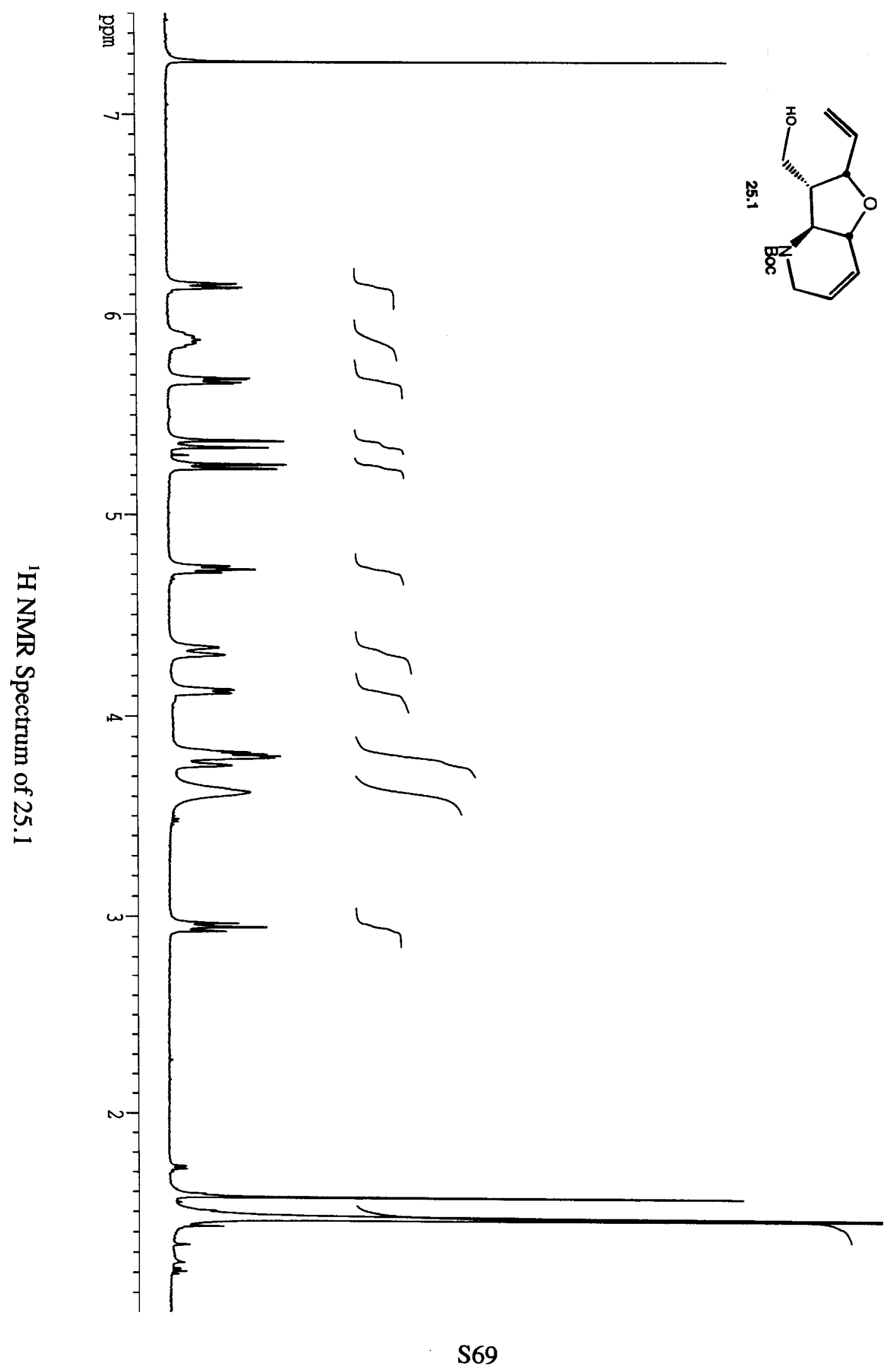




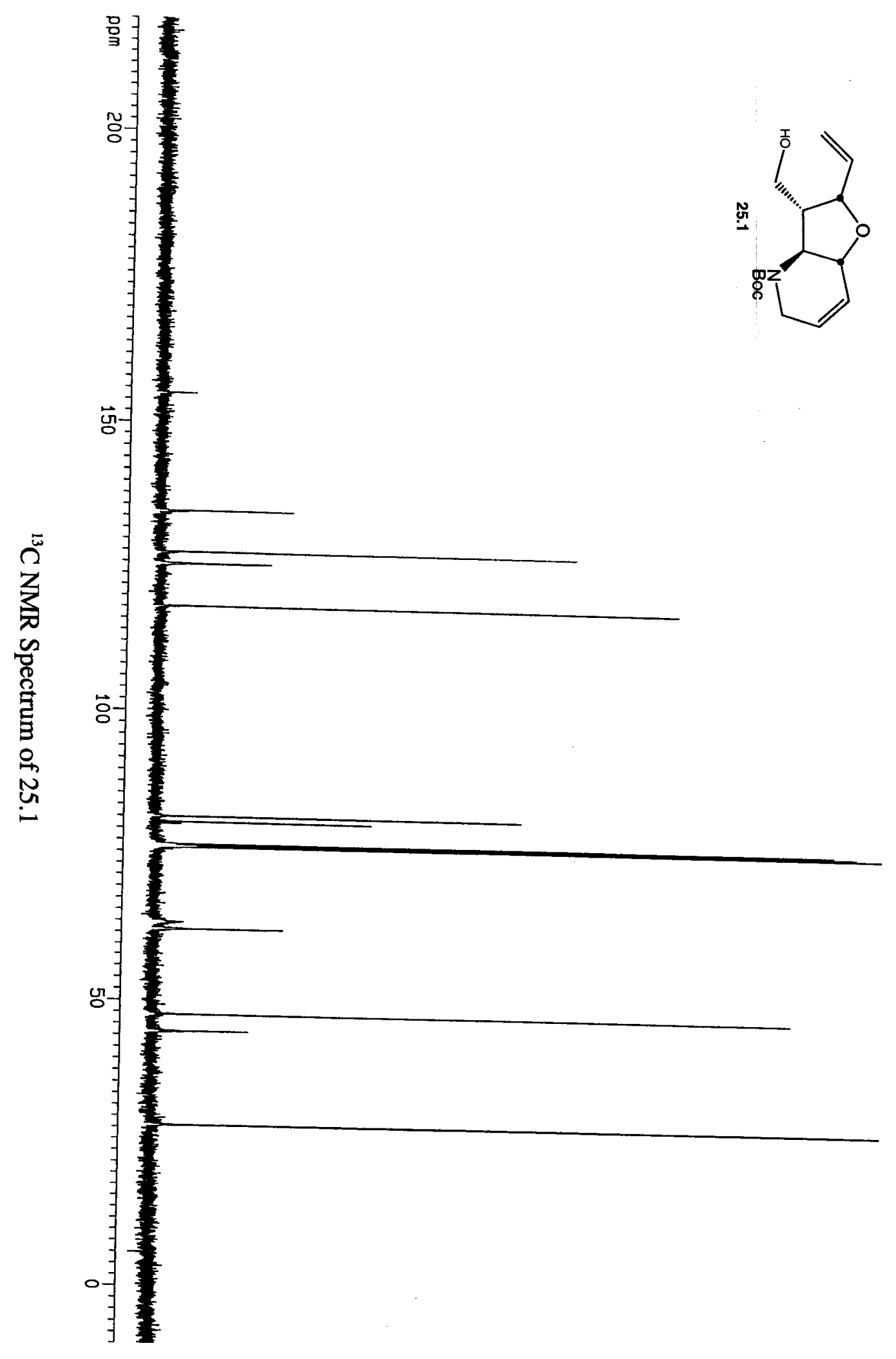

S-70 


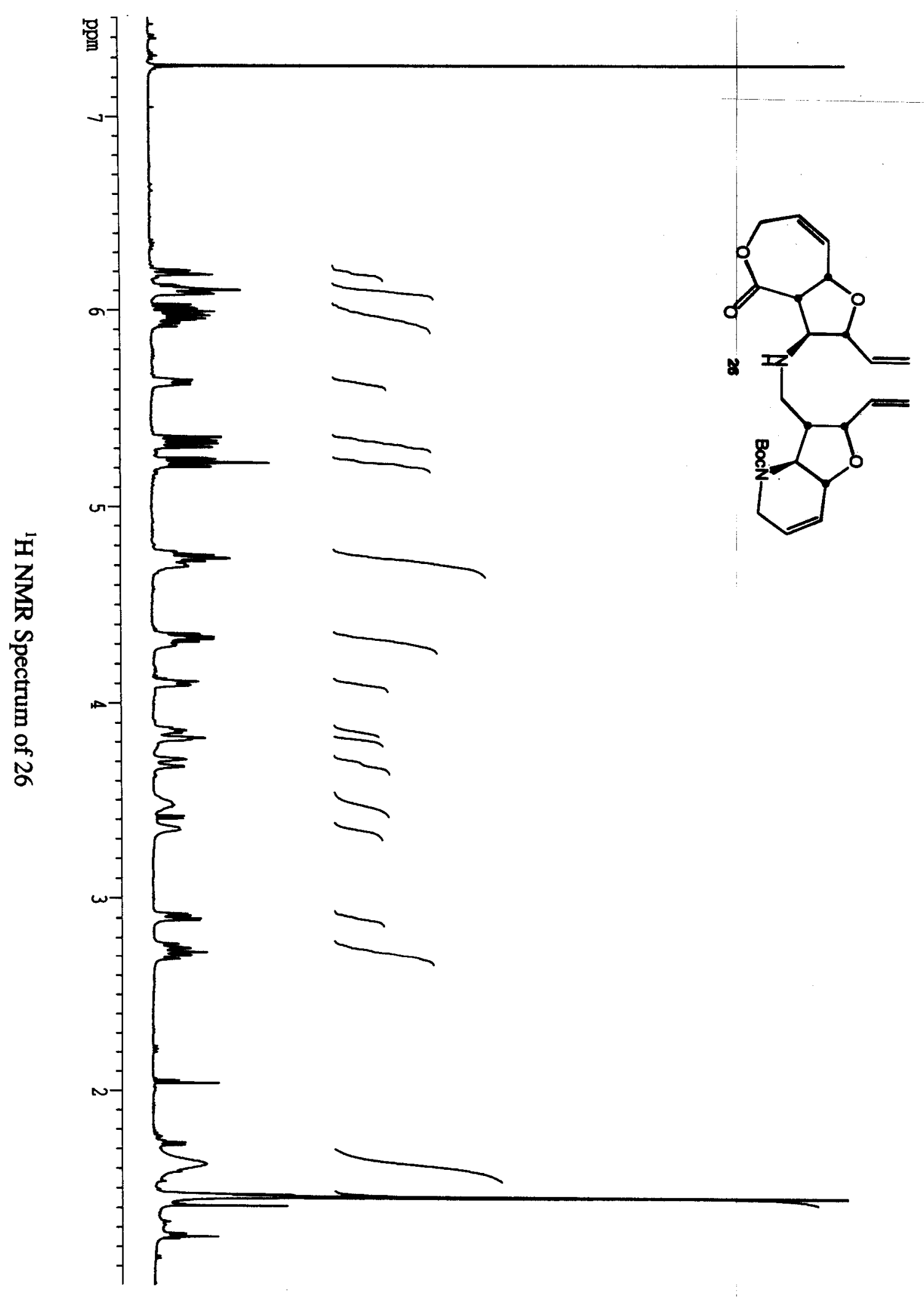



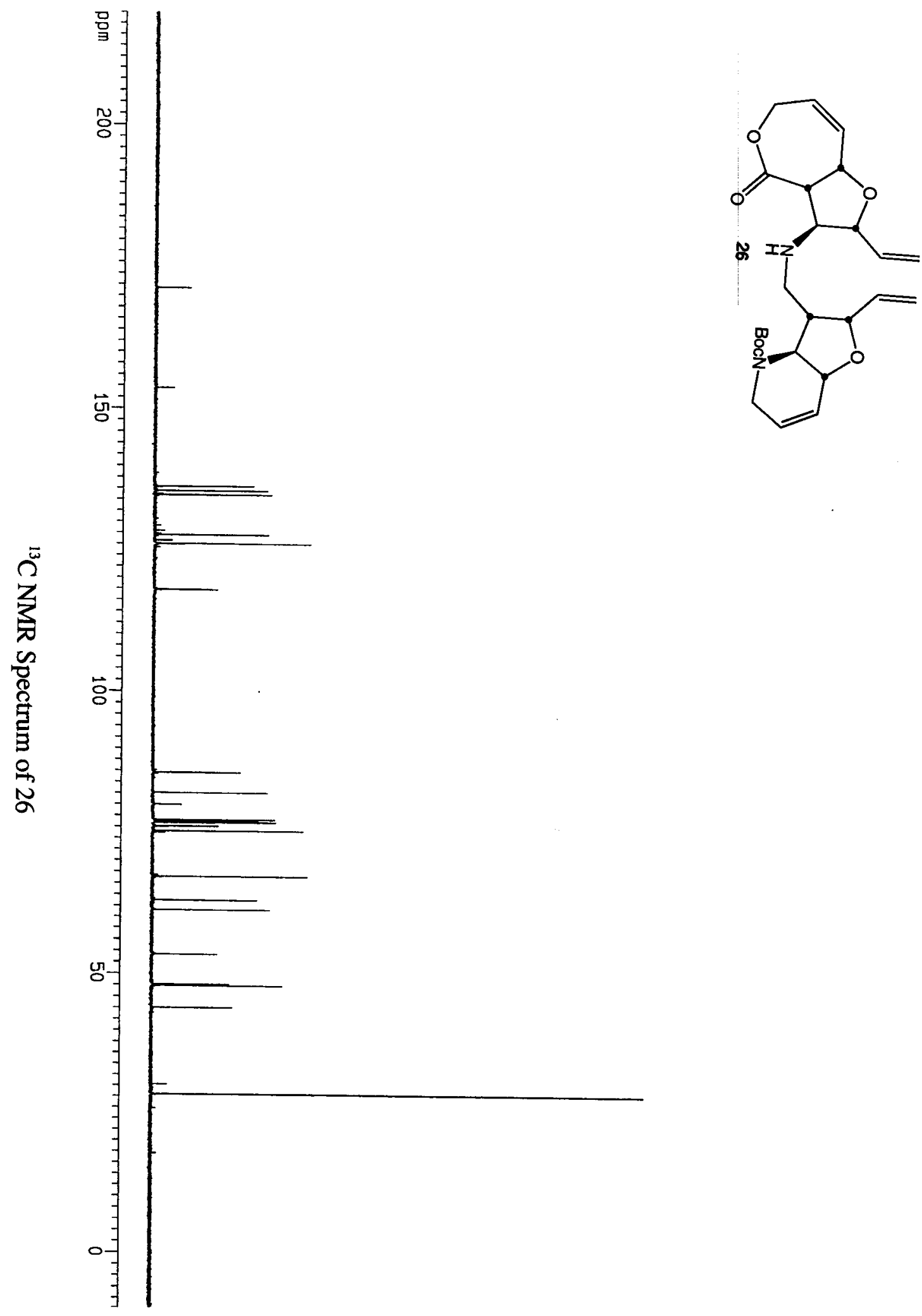


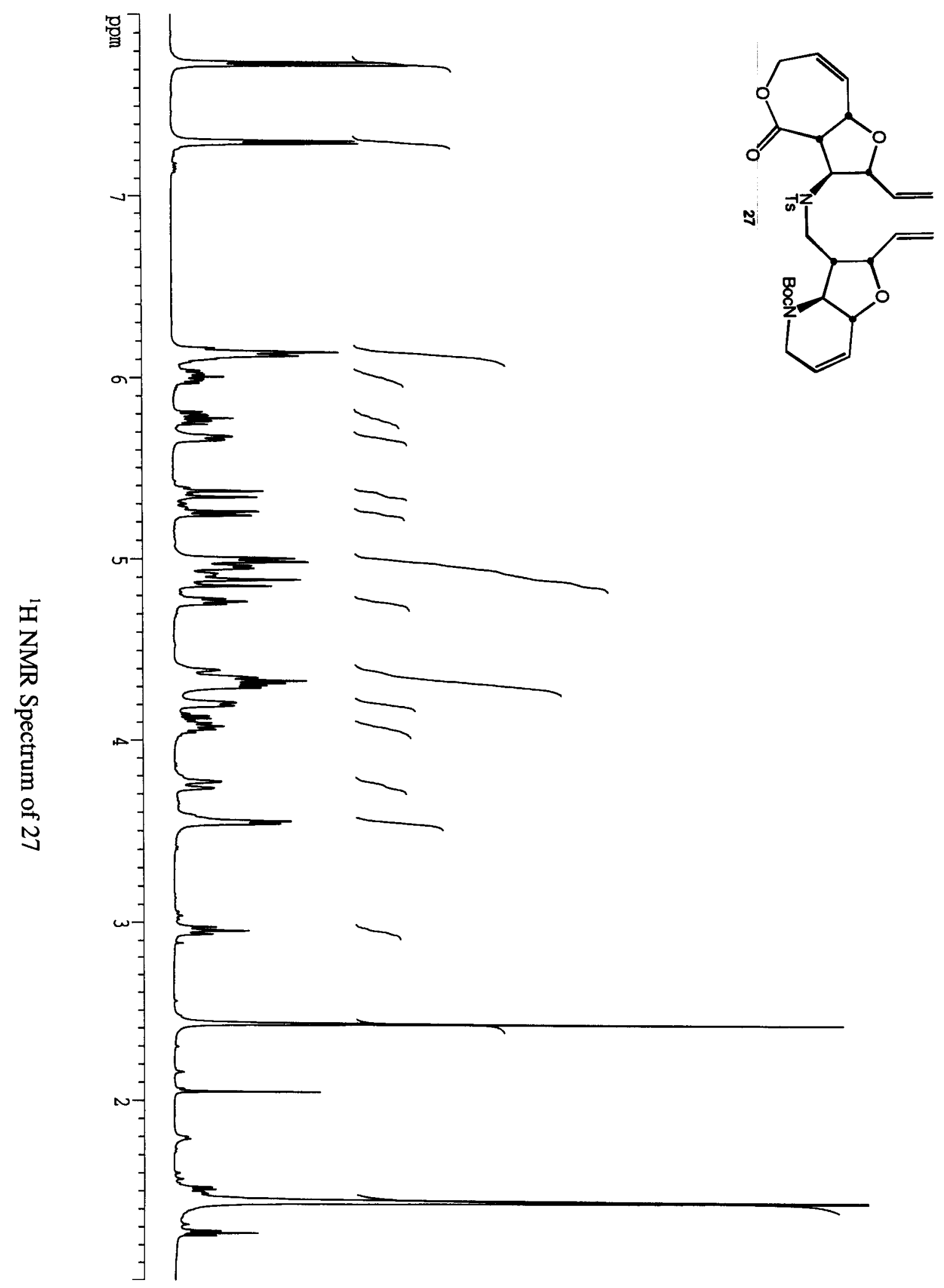




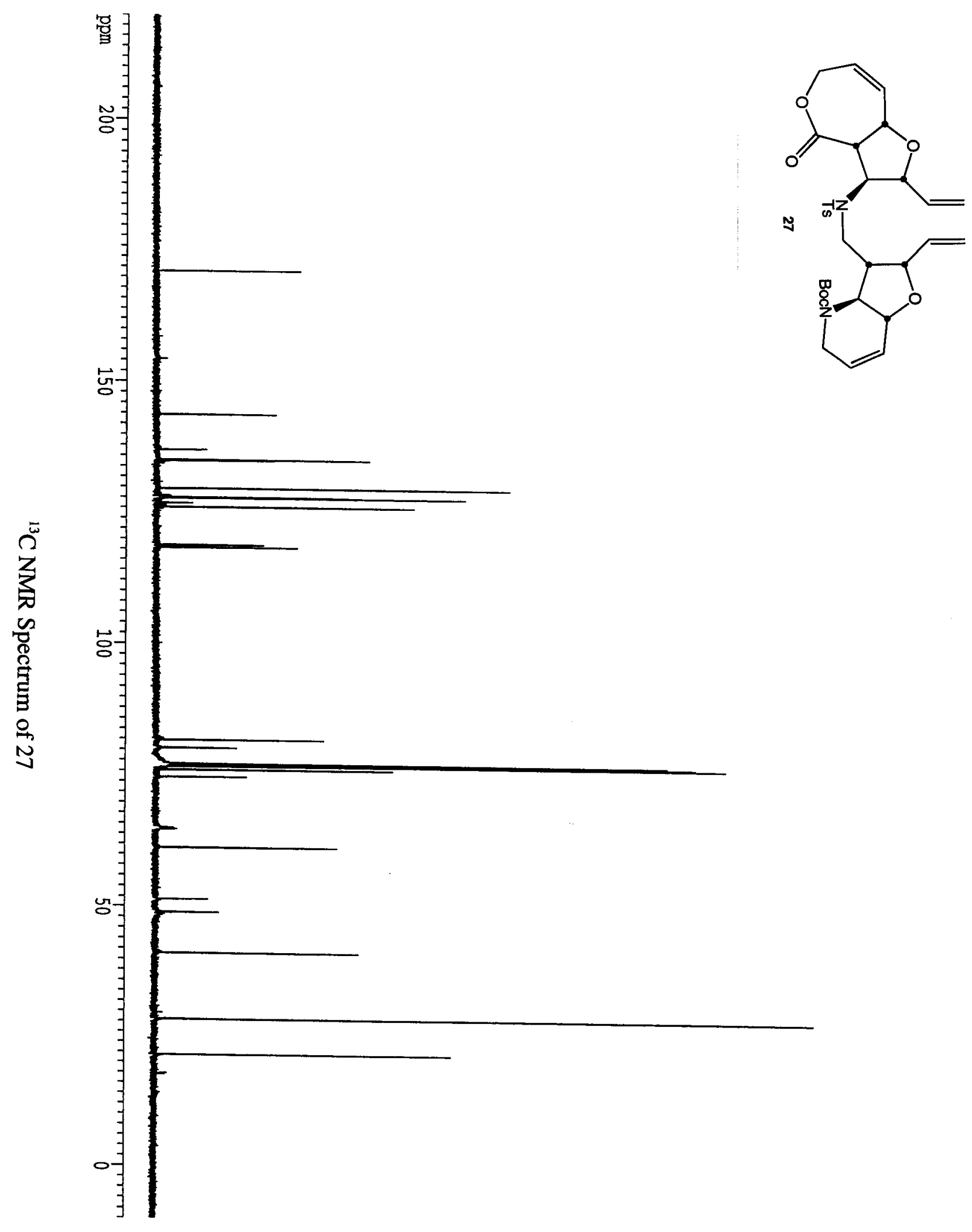




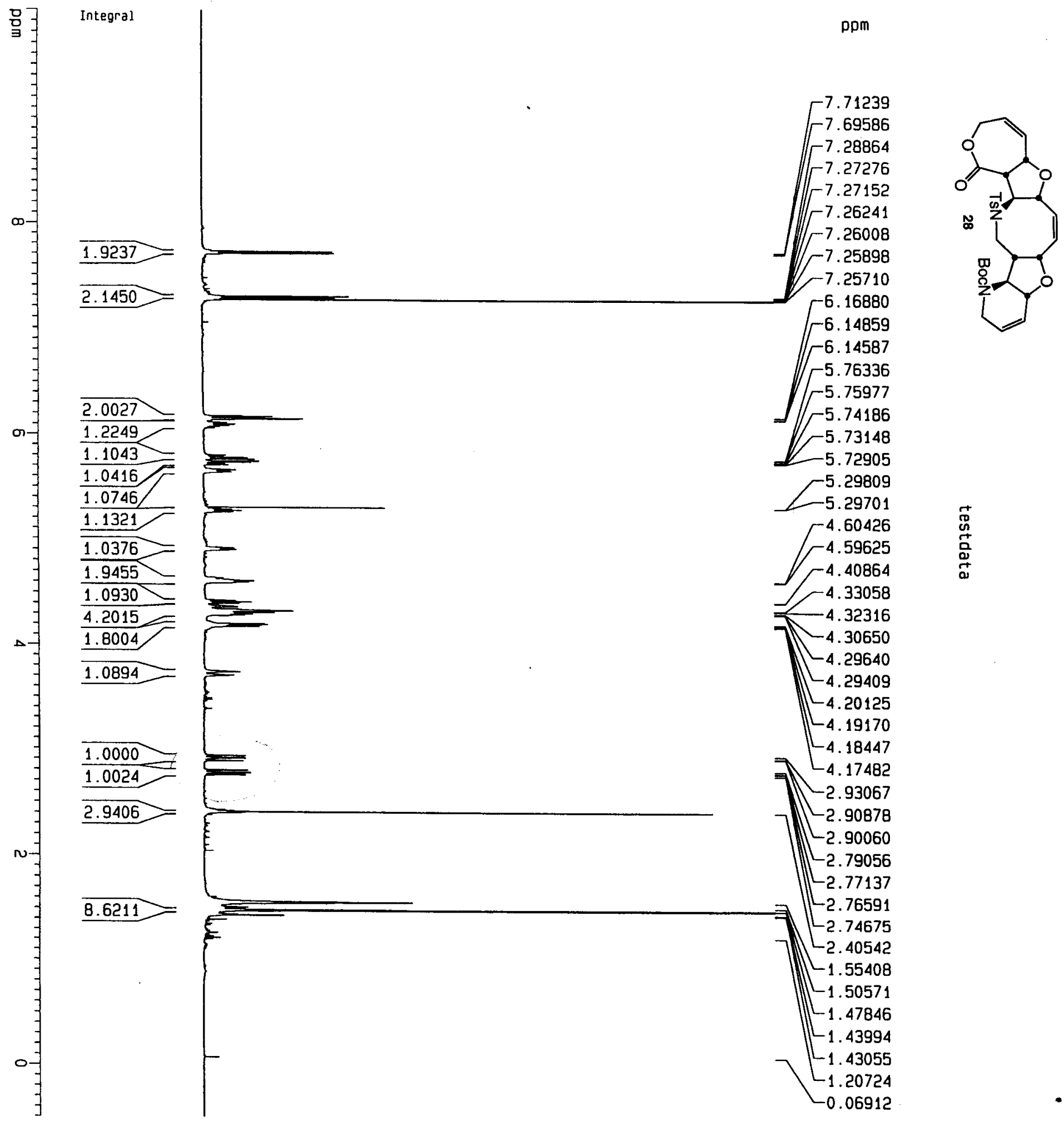




$$
\text { E }
$$




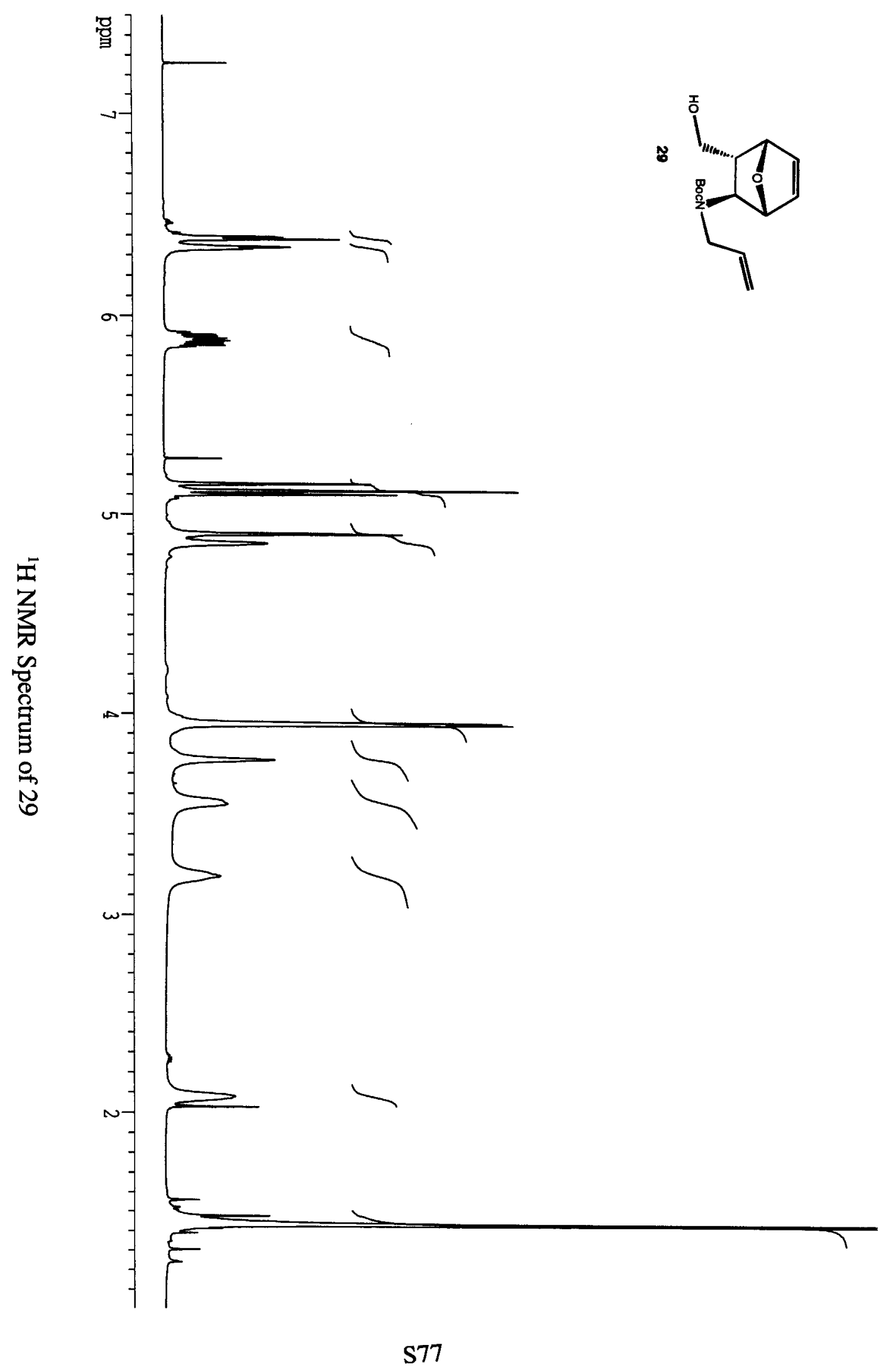




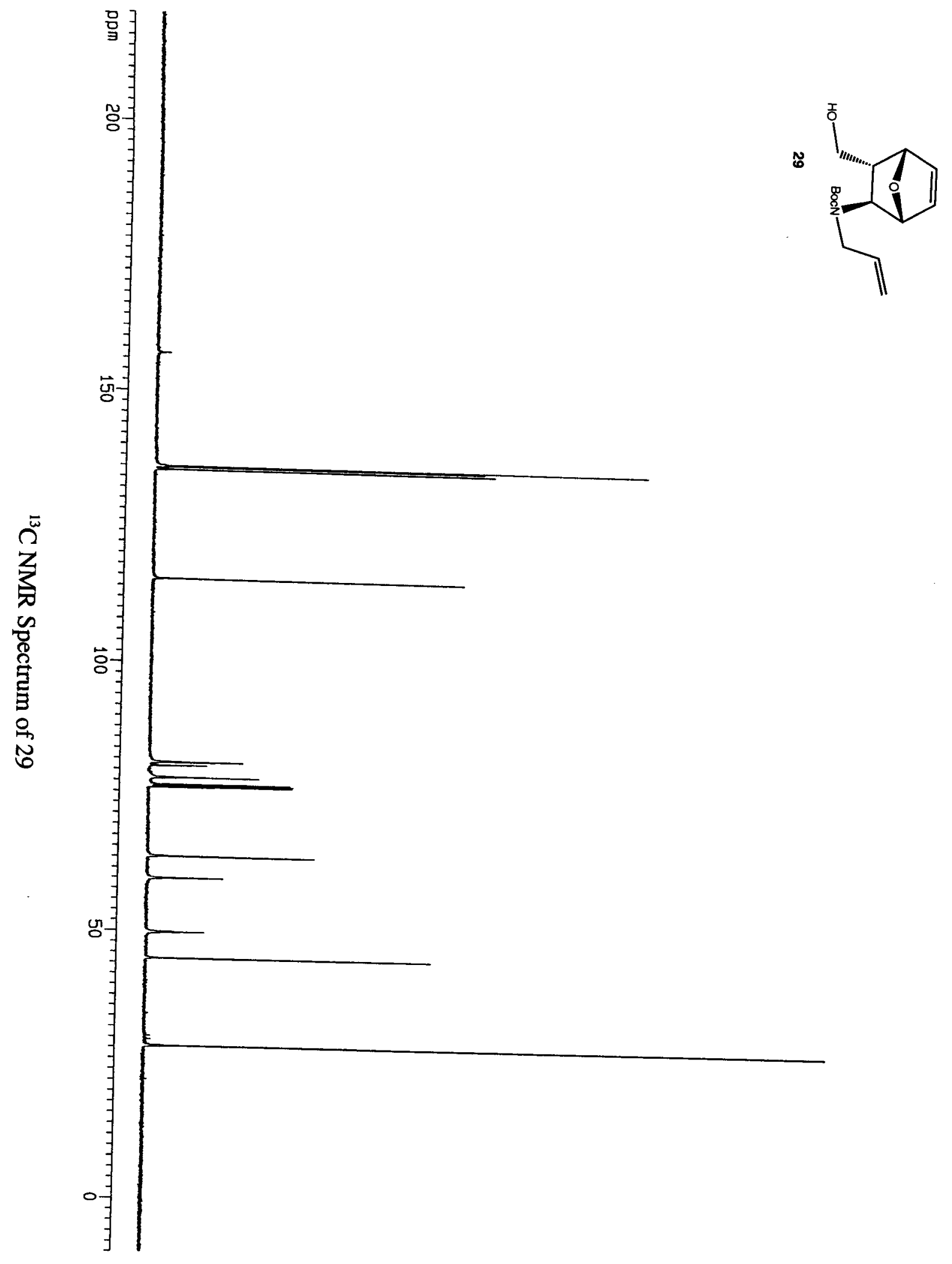




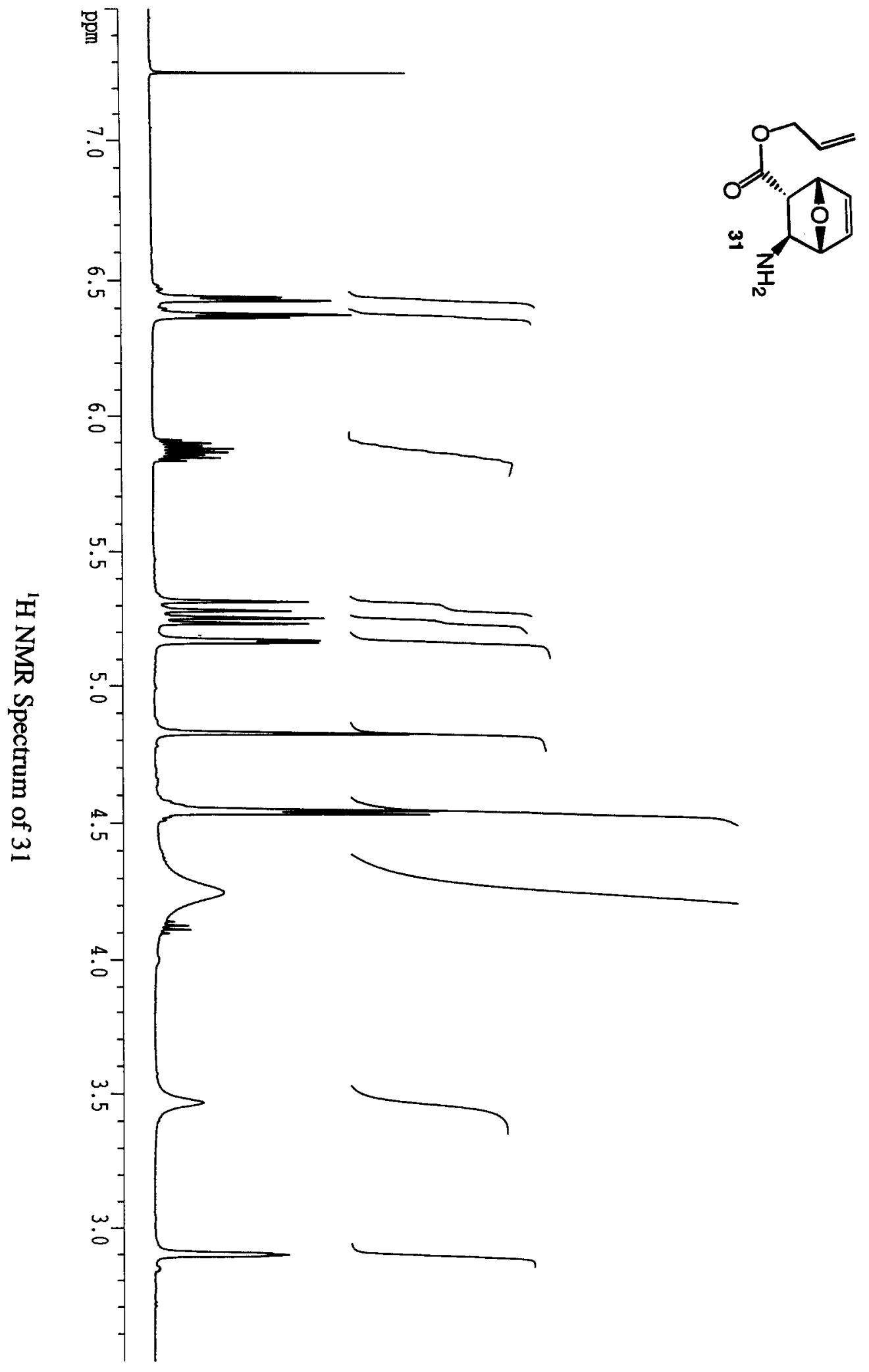




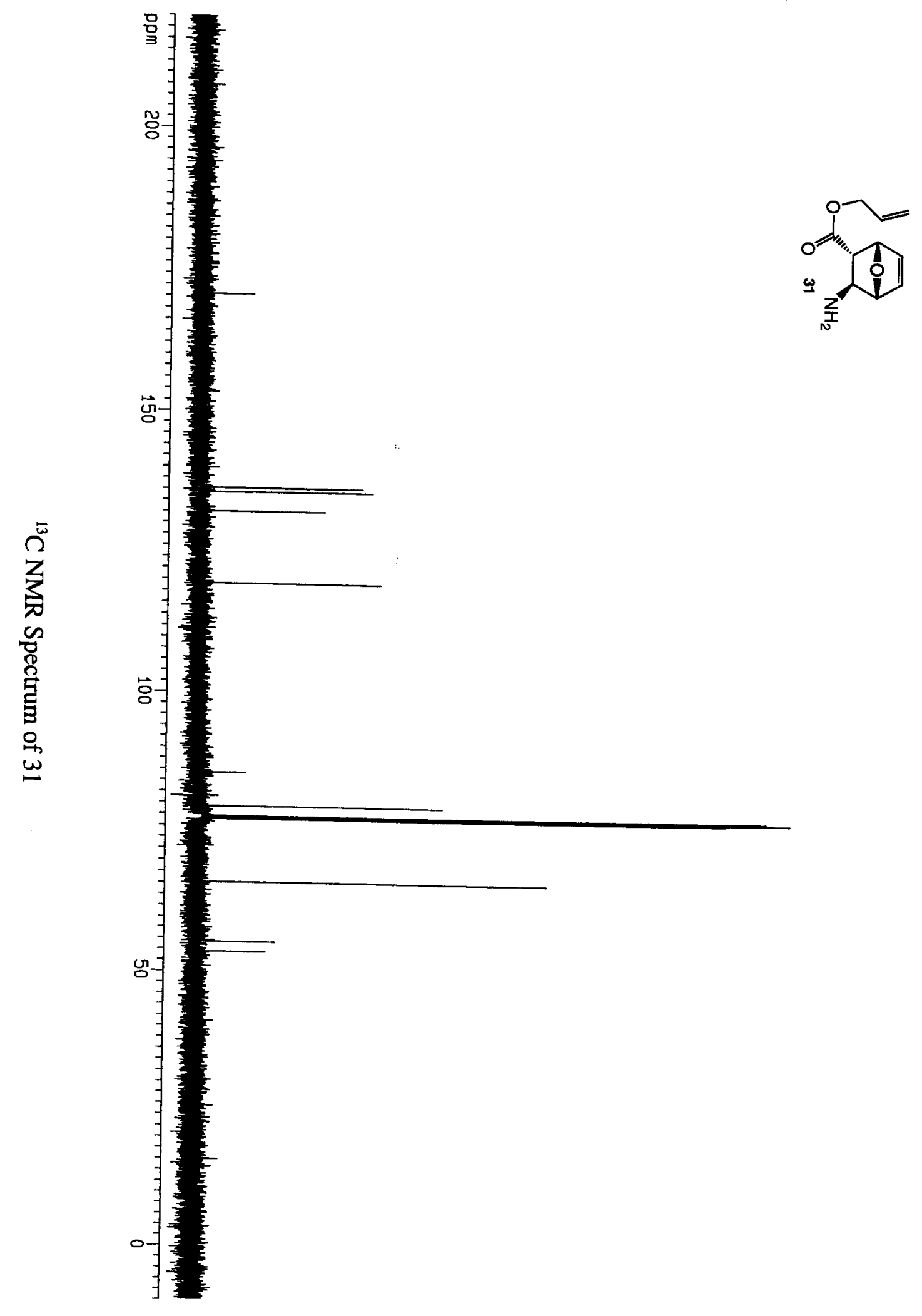




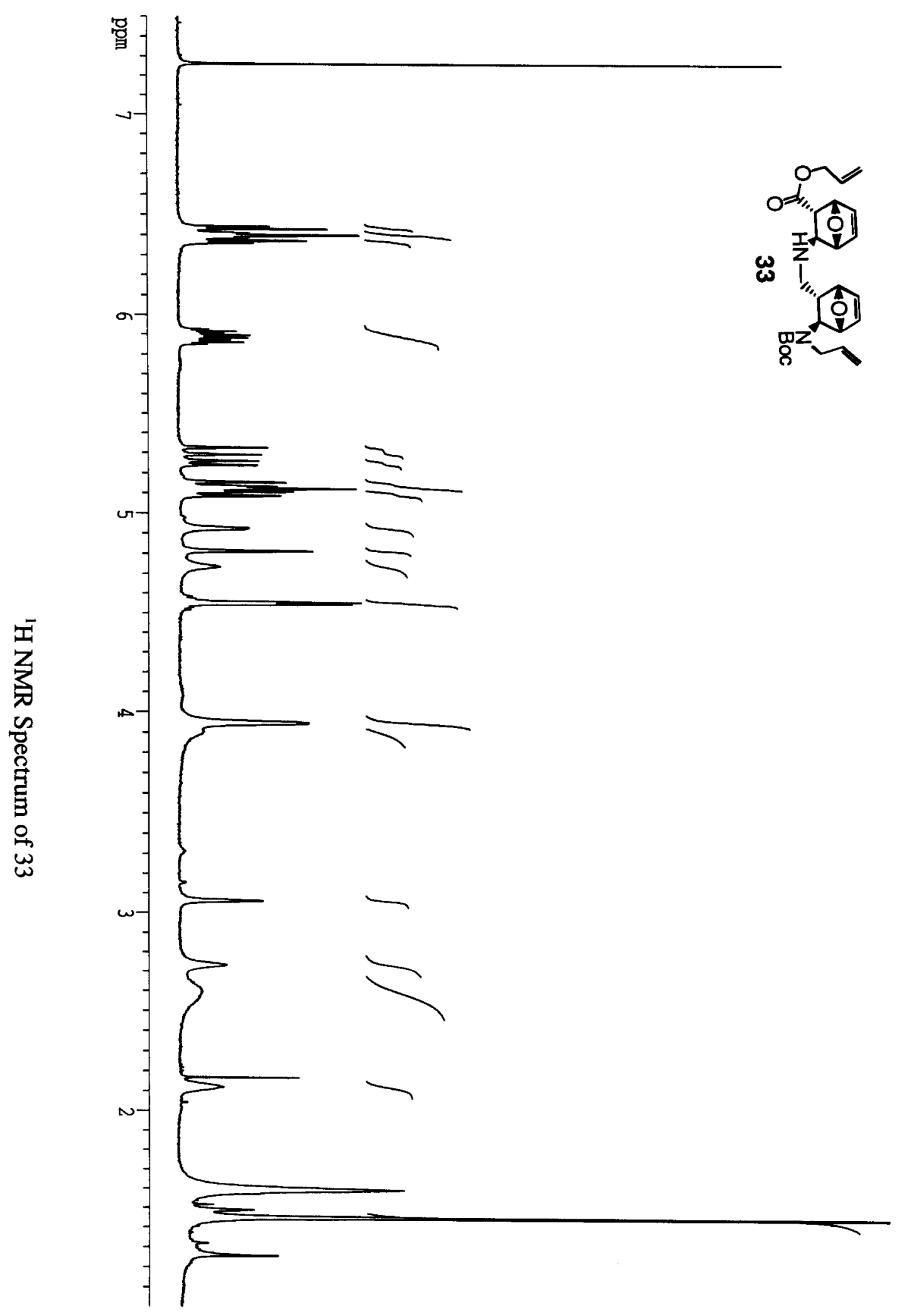




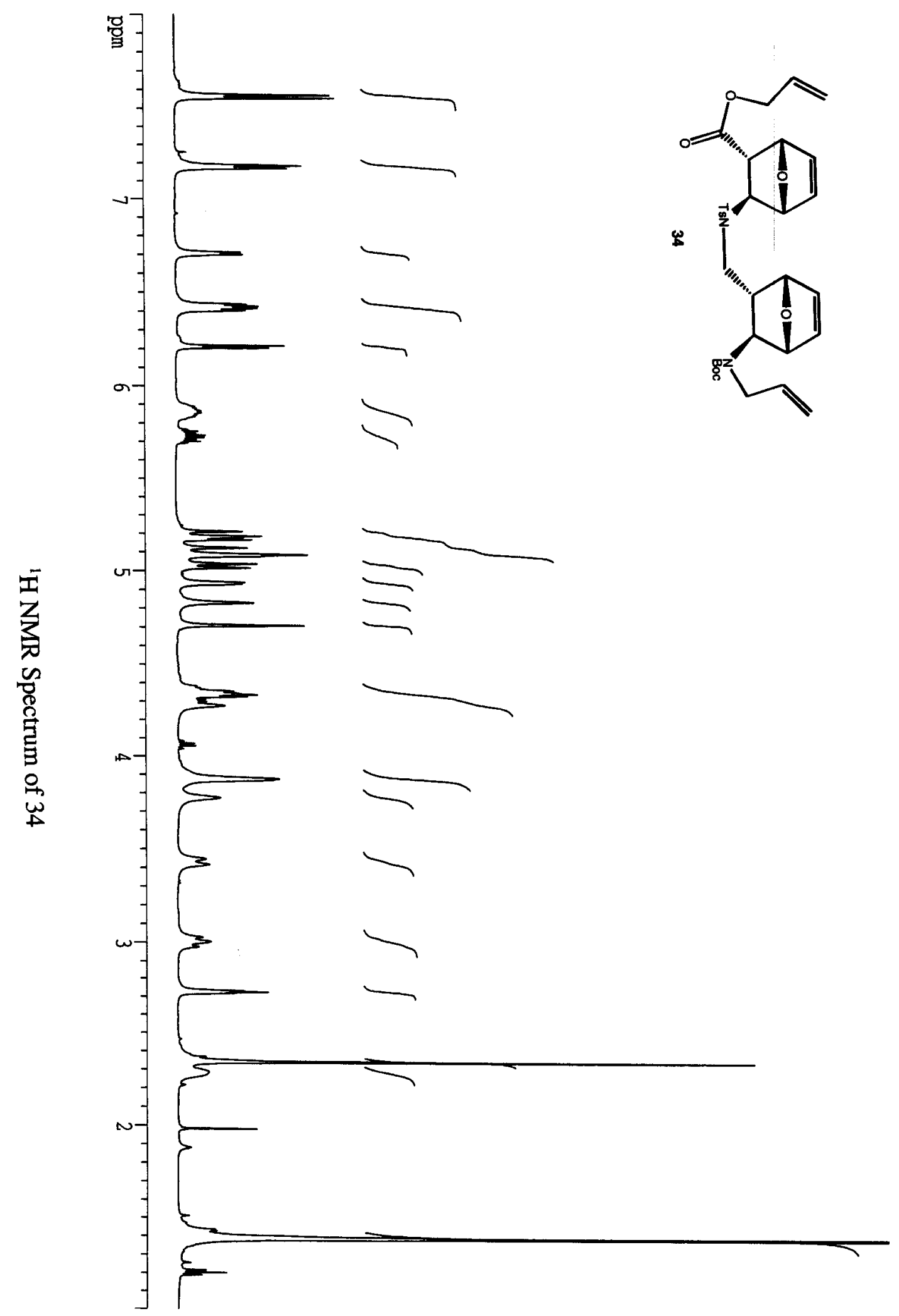



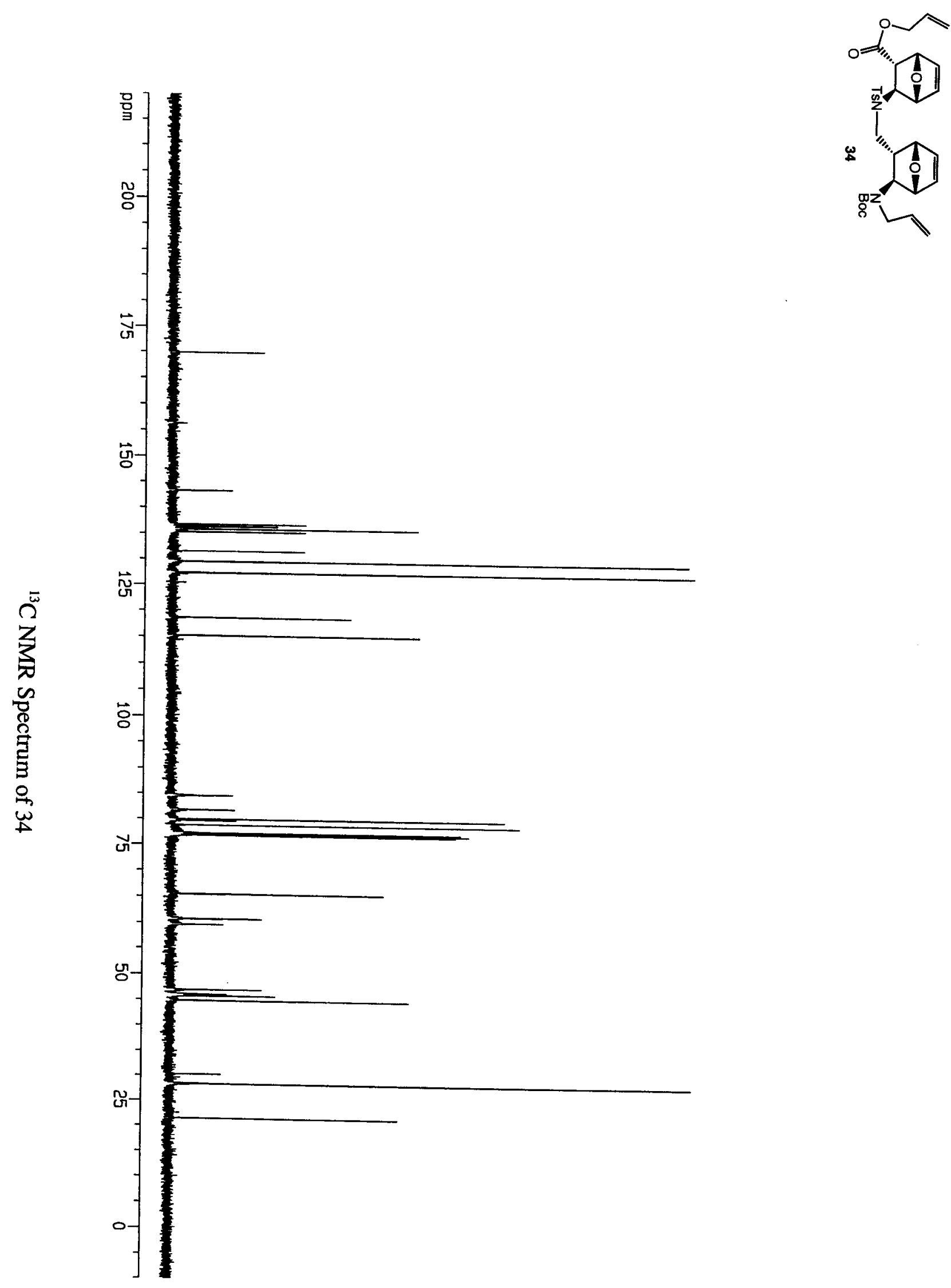